FINAL TECHNICAL REPORT

October 1, 2003 to September 30, 2007

Award Number DE-FC26-03NT41964

\title{
Design, Synthesis, and Mechanistic Evaluation of Iron-Based Catalysis for Synthesis Gas Conversion to Fuels and Chemicals
}

Principal Investigator

Project Personnel
Enrique Iglesia

Laboratory for the Science and Application of Catalysis

Department of Chemical Engineering

University of California at Berkeley

Berkeley, CA 94720

Akio Ishikawa (UC-Berkeley)

Manuel Ojeda (UC-Berkeley)

Nan Yao (UC-Berkeley) 


\section{DISCLAIMER:}

This report was prepared as an account of work sponsored by an agency of the United States Government. Neither the United States Government nor any agency thereof, nor any of their employees, makes any warranty, express or implied, or assumes any legal liability or responsibility for the accuracy, completeness, or usefulness of any information, apparatus, product, or process disclosed, or represents that its use would not infringe privately owned rights. Reference herein to any specific commercial product, process, or service by trade name, trademark, manufacturer, or otherwise does not necessarily constitute or imply its endorsement, recommendation, or favoring by the Unites States Government or any agency thereof. The views and opinions of authors expressed herein do not necessarily state or reflect those of the United States Government or any agency thereof. 


\section{EXECUTIVE SUMMARY}

A detailed study of the catalyst composition, preparation and activation protocol of Fe-based catalysts for the Fischer-Tropsch Synthesis (FTS) have been carried out in this project. We have studied the effects of different promoters on the catalytic performance of Fe-based catalysts. Specifically, we have focused on how their sequence of addition dramatically influences the performance of these materials in the Fischer-Tropsch synthesis. The resulting procedures have been optimized to improve further upon the already unprecedented rates and $\mathrm{C}_{5+}$ selectivities of the Fe-based catalysts that we have developed as part of this project. Selectivity to $\mathrm{C}_{5^{+}}$hydrocarbon was close to 90 $\%\left(\mathrm{CO}_{2}\right.$-free basis) and $\mathrm{CO}$ conversion rate was about $6.7 \mathrm{~mol} \mathrm{~h}^{-1} \mathrm{~g}$-at Fe ${ }^{-1}$ at $2.14 \mathrm{MPa}, 508 \mathrm{~K}$ and with substoichiometric synthesis gas; these rates were larger than any reported previously for Fe-based FTS catalysts at these conditions. We also tested the stability of Fe-based catalysts during FTS reaction (10 days); as a result, the high hydrocarbon formation rates were maintained during 10 days, though the gradual deactivation was observed. Our investigation has also focused on the evaluation of Fe-based catalysts with hydrogen-poor synthesis gas streams $\left(\mathrm{H}_{2} / \mathrm{CO}=1\right)$. We have observed that the Fe-based catalysts prepared in this project display also a high hydrocarbon synthesis rate with substoichiometric synthesis gas $\left(\mathrm{H}_{2} / \mathrm{CO}=1\right)$ stream, which is a less desirable reactant mixture than stoichiometric synthesis gas $\left(\mathrm{H}_{2} / \mathrm{CO}=2\right)$. We have improved the catalyst preparation protocols and achieved the highest FTS reaction rates and selectivities so far reported at the low temperatures required for selectivity and stability. Also, we have characterized the catalyst structural change and active phases formed, and their catalytic behavior during the activation process to evaluate their influences on FTS reaction. The efforts of this project led to (i) structural evolution of $\mathrm{Fe}-\mathrm{Zn}$ oxide promoted with $\mathrm{K}$ and $\mathrm{Cu}$, and (ii) evaluation of hydrocarbon and $\mathrm{CH}_{4}$ formation rates during activation procedures at various temperature and $\mathrm{H}_{2} / \mathrm{CO}$ ratios. On the basis of the obtained results, we suggest that lower reactor temperature can be sufficient to activate catalysts and lead to the high FTS performance.

In this project, we have also carried out a detailed kinetic and mechanistic study of the FischerTropsch Synthesis with Fe-based catalysts. We have proposed a reaction mechanism with two CO activation pathways: unassisted and $\mathrm{H}$-assisted. Both routes lead to the formation of the same surface monomers $\left(\mathrm{CH}_{2}\right)$. However, the oxygen removal mechanism is different. In the $\mathrm{H}$-assisted route, oxygen is removed exclusively as water, while oxygen is rejected as carbon dioxide in the unassisted $\mathrm{CO}$ dissociation. The validity of the mechanism here proposed has been found to be in agreement with the experimental observation and with theoretical calculations over a Fe(110) surface. Also, we have studied the validity of the mechanism that we propose by analyzing the $\mathrm{H}_{2} / \mathrm{D}_{2}$ kinetic isotope effect $\left(\mathrm{r}_{\mathrm{H}} / \mathrm{r}_{\mathrm{D}}\right)$ over a conventional iron-based Fischer-Tropsch catalyst Fe-Zn-K-Cu. We have observed experimentally that the use of $\mathrm{D}_{2}$ instead of $\mathrm{H}_{2}$ leads to higher hydrocarbons formation rates (inverse kinetic isotopic effect). On the contrary, primary carbon dioxide formation is not influenced. These experimental observations can be explained by two $\mathrm{CO}$ activation pathways.

We have also explored the catalytic performance of Co-based catalysts prepared by using inverse micelles techniques. We have studied several methods in order to terminate the silanol groups on $\mathrm{SiO}_{2}$ support including impregnation, urea homogeneous deposition-precipitation, or zirconium (IV) ethoxide titration. Although hydroxyl groups on the $\mathrm{SiO}_{2}$ surface are difficult to be stochiometrically titrated by $\mathrm{ZrO}_{2}$, a requirement to prevent the formation of strongly-interacting Co oxide species on $\mathrm{SiO}_{2}$, modification of $\mathrm{ZrO}_{2}$ on $\mathrm{SiO}_{2}$ surface can improve the Co clusters dispersion leading to a marked increase in the number of accessible Co sites. Inverse micelle method allowed the synthesis of small Co clusters on $\mathrm{SiO}_{2}$, but the required surfactant removal steps led to the re-oxidation of Co metal clusters and to the formation of difficult to reduce $\mathrm{CoO}_{\mathrm{x}}$ species. 


\section{TABLE OF CONTENTS}

TITLE PAGE $\quad 1$

DISCLAIMER $\quad 2$

EXECUTIVE SUMMARY 3

TABLE OF CONTENTS

I. FISCHER-TROPSCH SYNTHESIS ON IRON CATALYSTS 5

1. Fischer-Tropsch Synthesis on Fe-based with hydrogen-poor synthesis gas

1.1. Methodology

1.1.1. Synthesis of precursors and catalysts

1.1.2. Fischer-Tropsch Synthesis rates and selectivity measurements

1.2. Effect of promoters on Fischer-Tropsch Synthesis rate and selectivity

1.3. Effect of $\mathrm{H}_{2} / \mathrm{CO}$ ratio on the Fisher-Tropsch synthesis rate and selectivity $\left(\mathrm{H}_{2} / \mathrm{CO}=1\right.$ versus $\left.\mathrm{H}_{2} / \mathrm{CO}=2\right)$

1.4. Catalytic stability of $\mathrm{Fe}-\mathrm{Zn}-\mathrm{Cu}_{3}-\mathrm{K}_{6}$ materials

2. Structural evolution and spectroscopic studies of site requirements in Fe catalyzed

Fischer-Tropsch synthesis with hydrogen-poor synthesis gas feedstocks

2.1. Methodology.

2.1.1. Temperature-programmed reaction and isothermal transient measurements Fischer-Tropsch synthesis rates

2.1.2. X-Ray absorption spectroscopy

2.2. Catalytic behavior on iron based catalysts during the activation process.

2.3. Structural evolution studies by $\mathrm{X}$-ray absorption spectroscopy and mass Spectrometry

2.3.1 In situ structural evolution and products analysis during reactions on Fe-Zn$\mathrm{Cu}_{3}-\mathrm{K}_{6}$ in hydrogen-poor synthesis gas

2.3.2. In-situ structural characterization and product evolution profiles during catalytic activation at various temperatures.

2.3.3. Effect of activation temperature and $\mathrm{H}_{2} / \mathrm{CO}$ ratio on activation and FTS reactions

3. Mechanism and kinetics of the Fischer-Tropsch Synthesis on Fe-based catalysts

3.1. Influence of reactants partial pressure on hydrocarbon formation rate

3.2. $\mathrm{CO}_{2} / \mathrm{H}_{2} \mathrm{O}$ formation and oxygen removal selectivity

3.3. Fischer-Tropsch synthesis mechanism on Fe-based catalysts

3.4. Kinetic analysis of the Fischer-Tropsch Synthesis with Fe-based catalysts

3.5. Kinetic $\mathrm{H}_{2} / \mathrm{D}_{2}$ isotope effects on Fe-based catalysts.

3.5.1. $\mathrm{H}_{2} / \mathrm{D}_{2}$ effect on hydrocarbon formation rate.

3.5.2. $\mathrm{H}_{2} / \mathrm{D}_{2}$ effect on $\mathrm{CO}_{2}$ formation rate

3.5.3. Ratio of hydrocarbon formation rates $\left(r_{H} / r_{D}\right)$

II. FISCHER-TROPSCH SYNTHESIS ON COBALT CATALYSTS

4. Metal colloids as catalysts for the Fischer-Tropsch synthesis

4.1. Experimental methods.

4.1.1. Catalyst preparation.

4.1.2. Catalyst characterization.

4.1.3. Fischer-Tropsch synthesis.

4.2. Effect of $\mathrm{ZrO}_{2}$ modification on $\mathrm{SiO}_{2}$ surface silanol groups

4.3. Effect of preparation method on cobalt supported catalysts 


\section{FISCHER-TROPSCH SYNTHESIS ON IRON CATALYSTS}

\section{Fischer-Tropsch Synthesis on Fe-based with hydrogen-poor synthesis gas.}

Over the past 80 years, extensive efforts have been made in the Fischer-Tropsch Synthesis (FTS) field for developing catalysts that maximized conversion of synthesis gas into various types of hydrocarbons. Synthesis gas mixtures can be converted into useful fuels and petrochemicals by using Fe- and Co-based catalysts. An emerging interest in the use of hydrogen-poor synthesis gas $\left(\mathrm{H}_{2} / \mathrm{CO}=0.7-1\right)$ mixtures as FTS feeds, as a result of the growing use of coal and biomass, led us to consider the use of our previously developed state-of-the-art Fe-based catalysts with such reactant mixtures.

Fe-based catalysts with FTS activities and selectivities similar to those on Co-based catalyst were recently reported by our research group. Those catalysts with unusually high surface areas $\left(\sim 140 \mathrm{~m}^{2} \mathrm{~g}^{-1}\right)$ gave unprecedented activity and $C_{5+}$ selectivity with stoichiometric synthesis gas mixture $\left(\mathrm{H}_{2} / \mathrm{CO}=2\right)$. These catalysts were prepared by novel synthetic procedures that improve the dispersion and the density of the active structures formed during reaction. $\mathrm{Fe}$ based catalysts generally require the addition of alkali and transition metals in order to improve the FT performance. However, the optimization of catalyst composition with promoter has not been deeply investigated on these Fe-based catalysts with very high surface areas.

We have studied here the FTS performance of Fe-based catalysts promoted with different amounts of $\mathrm{K}, \mathrm{Cu}$ and $\mathrm{Ru}$. Our investigation was extended in order to evaluate the FTS performance of Fe-based catalysts with hydrogen-poor synthesis gas streams $\left(\mathrm{H}_{2} / \mathrm{CO}=1\right)$. We have found $\mathrm{C}_{5+}$ selectivities close to $90 \%\left(\mathrm{CO}_{2}\right.$-free basis) at a $\mathrm{CO}$ conversion rate of $6.7 \mathrm{~mol}$ $\mathrm{h}^{-1} \mathrm{~g}$-at $\mathrm{Fe}^{-1}$ at $2.14 \mathrm{MPa}$ and $508 \mathrm{~K}$. This rate is larger than any value reported previously in the literature with Fe-based FTS catalysts at these reaction conditions. We have also proved the stability of Fe-based catalysts during FTS reaction (10 days). Towards the end of the project, we briefly examined the viability of Co-based catalysts with high dispersion, prepared via novel deposition techniques and modified supports

\subsection{Methodology.}

\subsubsection{Synthesis of precursors and catalysts.}

$\mathrm{Fe}_{2} \mathrm{O}_{3}-\mathrm{Zn}$ precursors were prepared by co-precipitation from a mixed solution of $\mathrm{Fe}$ and $\mathrm{Zn}$ nitrates using ammonium carbonate. $\mathrm{Zn}$ was used as a textural promoter that increased the surface area of samples during FTS reaction [1]. A solution containing $\mathrm{Fe}\left(\mathrm{NO}_{3}\right)_{3}$ (Aldrich, $98 \%, 3.0 \mathrm{M}$ ) and $\mathrm{Zn}\left(\mathrm{NO}_{3}\right)_{2}$ (Aldrich, $98+\%, 1.4 \mathrm{M}$ ) at $\mathrm{Zn} / \mathrm{Fe}$ atomic ratio of 0.1 was added into a large flask containing deionized water $\left(c a .100 \mathrm{~cm}^{3}\right)$ at $353 \mathrm{~K}$ at a rate of $120 \mathrm{~cm}^{3} \mathrm{~h}^{-1}$ using a liquid pump. A $\left(\mathrm{NH}_{4}\right)_{2} \mathrm{CO}_{3}$ (Aldrich, $99.9 \%, 1.0 \mathrm{M}$ ) solution was added separately into this flask at rate required to maintain the $\mathrm{pH}$ at constant value of $7.0 \pm 0.1$, measured with a $\mathrm{pH}$ meter. The precipitated powders $(30 \mathrm{~g})$ were washed five times with isopropanol $\left(\mathrm{ca} .30 \mathrm{~cm}^{3} \mathrm{~g}\right.$ ${ }^{1}$ each time). The obtained samples were dried in ambient air at $393 \mathrm{~K}$ overnight, and then treated in flowing dry air at $543 \mathrm{~K}$ for $4 \mathrm{~h}$; this sample is denoted as the $\mathrm{Fe}-\mathrm{Zn}$ oxide precursor. The $\mathrm{Zn}$-containing phase formed is $\mathrm{ZnFe}_{2} \mathrm{O}_{4}$ with a cubic fraklinite spinel-type structure [2]. The XRD patterns for the obtained samples, however, showed rhombohedral hematite structure of $\mathrm{Fe}_{2} \mathrm{O}_{3}$ (with a small amount of $\alpha-\mathrm{FeOOH}$ with goethite structure) without detectable $\mathrm{ZnFe}_{2} \mathrm{O}_{4}$ because of the low $\mathrm{Zn}$ content.

The $\mathrm{Fe}-\mathrm{Zn}$ oxide precursors were promoted with $\mathrm{K}, \mathrm{Cu}$ and/or $\mathrm{Ru}$. Aqueous solutions of $\mathrm{K}_{2} \mathrm{CO}_{3}$ (Aldrich, $99.99 \%$ ), $\mathrm{Cu}\left(\mathrm{NO}_{3}\right)_{2}$ (Aldrich, $99.99 \%$ ), or ruthenium (III) nitrosylnitrate $\left[\mathrm{Ru}(\mathrm{NO})\left(\mathrm{NO}_{3}\right)_{\mathrm{x}}(\mathrm{OH})_{\mathrm{y}}(\mathrm{x}+\mathrm{y}=3)\right]$ (Aldrich, dilute nitric acid solution, $\left.\mathrm{Ru} 1.5 \%\right)$ were used as the sources of $\mathrm{K}, \mathrm{Cu}$ and $\mathrm{Ru}$.

The addition of promoters to Fe-Zn oxide precursors was accomplished using two different 
procedures (Scheme 1.1). The first process (route 1) was carried out according to a previously reported study [1]. Potassium was added by incipient wetness impregnation with solutions of the required concentration to give the target $\mathrm{K} / \mathrm{Fe}$ atomic ratio $(\mathrm{K} / \mathrm{Fe}=0.06)$. Next, the solid was dried overnight at $393 \mathrm{~K}$ in ambient air. $\mathrm{Cu}$ or $\mathrm{Ru}$ were then added at a $\mathrm{Cu} / \mathrm{Fe}$ and $\mathrm{Ru} / \mathrm{Fe}$ atomic ratio of $0.03(\mathrm{Cu}(\mathrm{Ru}) / \mathrm{Fe}=0.03)$ in a second step, followed by overnight drying at 393 $\mathrm{K}$ in ambient air. Finally, the samples were treated in flowing dry air at $543 \mathrm{~K}$ for $4 \mathrm{~h}$. The resulting oxide precursors are denoted throughout as Fe- $\mathrm{Zn}-\mathrm{K}_{6}, \mathrm{Fe}-\mathrm{Zn}-\mathrm{K}_{6}-\mathrm{Cu}_{3}$, and $\mathrm{Fe}-\mathrm{Zn}-\mathrm{K}_{6^{-}}$ $\mathrm{Ru}_{3}$, respectively. The subscripts denote the atomic content of the corresponding promoter divided by the Fe atomic content $(\times 100)$.

The other process (Route 2) was carried out as follows. First, $\mathrm{Cu}$ or $\mathrm{Ru}$ were added to the $\mathrm{Fe}-\mathrm{Zn}$ oxide precursor at $\mathrm{Cu}(\mathrm{Ru}) / \mathrm{Fe}$ atomic ratios $(\mathrm{Cu}(\mathrm{Ru}) / \mathrm{Fe}=0.03)$, followed by overnight drying at $393 \mathrm{~K}$ in ambient air and drying at $543 \mathrm{~K}$ for $4 \mathrm{~h}$ in flowing dry air. Potassium was then added at $\mathrm{K} / \mathrm{Fe}$ atomic ratios $(\mathrm{K} / \mathrm{Fe}=0.06)$ in the second step, followed by overnight drying at $393 \mathrm{~K}$ in ambient air. These samples were again treated in flowing dry air at $543 \mathrm{~K}$ for $4 \mathrm{~h}$. The resulting oxide precursors are denoted as $\mathrm{Fe}-\mathrm{Zn}-\mathrm{Cu}_{3}-\mathrm{K}_{6}$ and $\mathrm{Fe}-\mathrm{Zn}-\mathrm{Ru}_{3}-\mathrm{K}_{6}$, respectively. These catalysts were pressed into pellets, lightly crushed, and then sieved to retain the 100-180 $\mu \mathrm{m}$ fraction for FTS reaction.

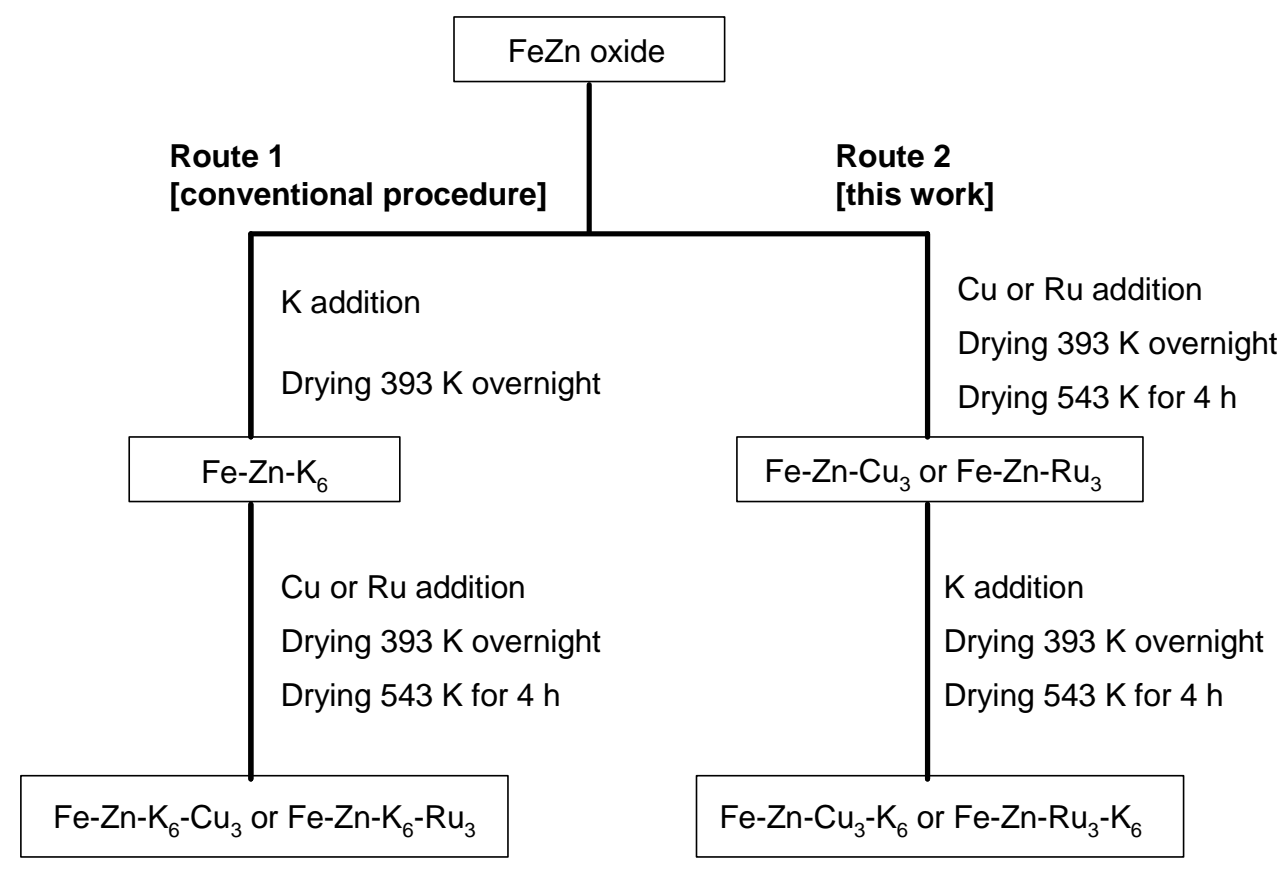

Scheme 1.1. Procedure for preparation of Fe-based catalysts with promoters.

\subsubsection{Fischer-Tropsch Synthesis rates and selectivity measurements.}

Fischer-Tropsch synthesis rates and selectivities were measured in a single-pass packedbed reactor with plug-flow hydrodynamics. This reactor was held within a resistively heated three-zone furnace. All lines after the reactor were kept at 433-553 K and a vessel was placed immediately after the reactor and held at $408 \mathrm{~K}$ in order to collect liquid products. The reactant and product streams were analyzed on-line using a gas chromatograph (Agilent Technologies, model $6890 \mathrm{~N}$ ). The analysis of $\mathrm{N}_{2}, \mathrm{CO}, \mathrm{CO}_{2}$, and $\mathrm{CH}_{4}$ was performed using a thermal conductivity detector and a Porapak Q packed-column $(15.2 \mathrm{~cm} \times 0.318 \mathrm{~cm})$. All hydrocarbons up to $\mathrm{C}_{15}$ were analyzed using a flame ionization detector and a cross-linked methyl silicone capillary column (HP-1, $50 \mathrm{~m} \times 0.32 \mathrm{~mm} ; 1.05 \mu \mathrm{m}$ film).

Fe catalysts $(100-180 \mu \mathrm{m}, 0.4 \mathrm{~g})$ were diluted with $11 \mathrm{~g}$ of quartz granules $(100-180 \mu \mathrm{m})$ in 
order to avoid temperature gradients. Quartz was washed with concentrated nitric acid and treated in air at $973 \mathrm{~K}$ before use. The catalysts were activated using flowing synthesis gas (Praxair; $\mathrm{H}_{2} / \mathrm{CO} / \mathrm{N}_{2}$ mixture; $0.62 / 0.31 / 0.07, \mathrm{H}_{2} / \mathrm{CO}=2$ ) at $0.1 \mathrm{MPa}$ by increasing the temperature from 298 to $423 \mathrm{~K}$ at a rate of $10 \mathrm{~K} \mathrm{~min}^{-1}$ and from 423 to $543 \mathrm{~K}$ at $1 \mathrm{~K} \mathrm{~min}^{-1}$. The catalysts were held at $543 \mathrm{~K}$ for $1 \mathrm{~h}$. After the activation process, the temperature was decreased to $508 \mathrm{~K}$, and the synthesis gas $\left(\mathrm{H}_{2} / \mathrm{CO}=2\right)$ was switched to a flow of synthesis gas with the target 1:1 $\mathrm{H}_{2}: \mathrm{CO}$ ratio (Praxair; $\mathrm{H}_{2} / \mathrm{CO} / \mathrm{N}_{2}$ mixture; $\left(0.46 / 0.46 / 0.08, \mathrm{H}_{2} / \mathrm{CO}=1\right.$ ). The pressure was then gradually increased to $2.14 \mathrm{MPa}$. FTS reactions were carried out at 2.14 MPa total pressure and $508 \mathrm{~K}$.

\subsection{Effect of promoters on Fischer-Tropsch Synthesis rate and selectivity.}

The promotion effects of $\mathrm{K}, \mathrm{Cu}$ and $\mathrm{Ru}$ on the catalytic behavior of $\mathrm{Fe}-\mathrm{Zn}$ oxide catalysts were examined with sub-stoichiometric synthesis gas reactants $\left(\mathrm{H}_{2} / \mathrm{CO}=1\right)$ at $508 \mathrm{~K}$ and 2.14 $\mathrm{MPa}$. The relative composition of $\mathrm{Fe} / \mathrm{Zn} / \mathrm{K} / \mathrm{Cu}($ or $\mathrm{Ru})$ and $\mathrm{BET}$ surface areas are summarized in Table 1.1. Fe- $\mathrm{Zn}$ catalysts with various loadings of $\mathrm{K}, \mathrm{Cu}$ and $\mathrm{Ru}$ were obtained by using two different procedures, as described in the experimental section. The measured surface areas were 251-291 $\mathrm{m}^{2} \mathrm{~g}^{-1}$ for the oxyhydroxide precipitates obtained by drying in ambient air at 393 $\mathrm{K}$. The heat treatment in flowing air at $543 \mathrm{~K}$ for $4 \mathrm{~h}$ led to the decrease of the surface area for $\mathrm{Fe}-\mathrm{Zn}$ oxide because of the sintering of $\mathrm{Fe}-\mathrm{Zn}$ oxide precursors during the decomposition of the oxyhydroxide precursors. Besides, the addition of $\mathrm{K}, \mathrm{Cu}$ and/or $\mathrm{Ru}$ promoters to $\mathrm{Fe}-\mathrm{Zn}$ oxides also led to the decrease of their surface areas because of the pore collapse during the evaporation of intrapellet water.

Table 1.2 shows the FTS rates and selectivities obtained with the Fe-based catalysts at similar $\mathrm{CO}$ conversion levels. Fe- $\mathrm{Zn}-\mathrm{K}_{6}$ showed the best FT performance (highest $\mathrm{C}_{5+}$ selectivity, lowest $\mathrm{CH}_{4}$ and $\mathrm{C}_{2}-\mathrm{C}_{4}$ selectivity, especially the olefin contents) compared to those on $\mathrm{Fe}-\mathrm{Zn}-\mathrm{K}_{4}$ because $\mathrm{K}$ promotes the $\mathrm{CO}$ chemisorption and inhibits $\mathrm{H}_{2}$ chemisorption, which leads to lower FTS rates, higher product molecular weight and greater olefin content [3]. The further increase of $\mathrm{K} / \mathrm{Fe}$ atomic ratio from 0.06 to $0.08\left(\mathrm{Fe}-\mathrm{Zn}-\mathrm{K}_{8}\right)$, however, did not cause significant changes in the FTS performance (data not shown). Therefore, a K/Fe ratio of 0.06 was chosen as optimal to study the effects of $\mathrm{Cu}$ and $\mathrm{Ru}$ on FTS reaction rates and selectivities. $\mathrm{CO}$ conversion rate increased when $\mathrm{Ru}$ or $\mathrm{Cu}$ was added to $\mathrm{Fe}-\mathrm{Zn}-\mathrm{K}_{6}$, suggesting that $\mathrm{Ru}$ and $\mathrm{Cu}$ species promote carburization and reduction rates. The $\mathrm{Ru}$ component is not expected to lead to detectable catalytic contributions at the conditions of these experiments. These promoter effects lead to either a larger number of active sites or to sites with a higher intrinsic activity. In contrast, $\mathrm{Fe}-\mathrm{Zn}-\mathrm{Cu}_{3}-\mathrm{K}_{6}$ and $\mathrm{Fe}-\mathrm{Zn}-\mathrm{Ru}_{3}-\mathrm{K}_{6}$ prepared by the different promoter introduction protocols, as described in experimental section, showed much higher $\mathrm{CO}$ conversion rates and more favorable FTS performance compared to those on $\mathrm{Fe}-\mathrm{Zn}-\mathrm{K}_{6}-\mathrm{Cu}_{3}$ and $\mathrm{Fe}-\mathrm{Zn}-\mathrm{K}_{6}-\mathrm{Ru}_{3}$. These different FTS performances on $\mathrm{Fe}-\mathrm{Zn}$ oxides promoted by $\mathrm{K}$ and $\mathrm{Cu}$ (or $\mathrm{Ru}$ ) reflect the marked differences in promoter dispersion and placement as a result of the promoter addition protocols.

Table 1.1. List of prepared catalysts and BET surface areas.

\begin{tabular}{|c|c|c|c|c|c|c|}
\hline & \multicolumn{5}{|c|}{ Relative composition (at.\%) } & \multirow{2}{*}{$\begin{array}{c}\text { BET surface area } \\
\left(\mathrm{m}^{2} \mathrm{~g}^{-1}\right)\end{array}$} \\
\hline & $\mathrm{Fe}$ & $\mathrm{Zn}$ & $\mathrm{K}$ & $\mathrm{Cu}$ & $\mathrm{Ru}$ & \\
\hline $\mathrm{FeZn}$ & 100 & 10 & - & - & - & 198 \\
\hline $\mathrm{FeZnK}_{4}$ & 100 & 10 & 4 & - & - & 178 \\
\hline
\end{tabular}




\begin{tabular}{ccccccc}
$\mathrm{FeZnK}_{6}$ & 100 & 10 & 6 & - & - & 168 \\
$\mathrm{FeZnK}_{6} \mathrm{Cu}_{3}$ & 100 & 10 & 6 & 3 & - & 141 \\
$\mathrm{FeZnK}_{6} \mathrm{Ru}_{3}$ & 100 & 10 & 6 & - & 3 & 147 \\
$\mathrm{FeZnCu}_{3} \mathrm{~K}_{6}$ & 100 & 10 & 6 & 3 & - & 159 \\
$\mathrm{FeZnRu}_{3} \mathrm{~K}_{6}$ & 100 & 10 & 6 & - & 3 & 163 \\
\hline
\end{tabular}

Table 1.2. Steady-state performance ${ }^{\mathrm{a}}$ of $\mathrm{Fe}$-based catalysts $(\mathrm{Zn} / \mathrm{Fe}=0.1)$ with different loadings of $\mathrm{K}, \mathrm{Cu}$, and $\mathrm{Ru}$.

\begin{tabular}{|c|c|c|c|c|c|c|}
\hline & $\mathrm{FeZnK}_{4}$ & $\mathrm{FeZnK}_{6}$ & $\mathrm{FeZnK}_{6} \mathrm{Cu}_{3}$ & $\mathrm{FeZnCu}_{3} \mathrm{~K}_{6}$ & $\mathrm{FeZnK}_{6} \mathrm{Ru}_{3}$ & $\mathrm{FeZnRu}_{3} \mathrm{~K}_{6}$ \\
\hline $\begin{array}{l}\text { CO conversion rate } \\
\left(\mathrm{mol} \mathrm{h}^{-1} \text { g-at Fe }{ }^{-1}\right)\end{array}$ & 2.1 & 2.2 & 4.4 & 6.7 & 3.2 & 5.1 \\
\hline $\begin{array}{l}\mathrm{HC} \text { formation rate } \\
\left(\mathrm{mol} \mathrm{h}^{-1} \mathrm{~g} \text {-at } \mathrm{Fe}^{-1}\right)\end{array}$ & 1.5 & 1.6 & 3.2 & 5.1 & 2.2 & 3.6 \\
\hline $\mathrm{CO}_{2}$ selectivity (\%) & 28.1 & 29.0 & 28.3 & 25.9 & 31.5 & 30.7 \\
\hline $\mathrm{CH}_{4}$ selectivity $(\%)^{\mathrm{b}}$ & 4.3 & 3.9 & 2.8 & 1.9 & 4.5 & 2.7 \\
\hline $\mathrm{C}_{5+}$ selectivity $(\%)^{\mathrm{b}}$ & 82.3 & 84.0 & 85.7 & 87.6 & 80.0 & 85.5 \\
\hline $\mathrm{C}_{2}-\mathrm{C}_{4}(\%)^{\mathrm{b}}$ & 12.2 & 11.8 & 11.2 & 10.0 & 14.7 & 11.1 \\
\hline $1-\mathrm{C}_{5} \mathrm{H}_{10} / n-\mathrm{C}_{5} \mathrm{H}_{12}$ & 2.3 & 2.5 & 2.8 & 3.1 & 2.5 & 2.7 \\
\hline $1-\mathrm{C}_{10} \mathrm{H}_{20} / n-\mathrm{C}_{10} \mathrm{H}_{22}$ & 0.5 & 1.5 & 1.3 & 2.1 & 1.5 & 1.8 \\
\hline
\end{tabular}

Many studies have described the phenomenological effects of promoters on FTS [4-6], without specific or rigorous attention to the effects of addition sequence. Therefore, we discuss here the differences in FTS performance between $\mathrm{Fe}-\mathrm{Zn}-\mathrm{K}_{6}-\mathrm{Cu}(\mathrm{Ru})_{3}$ and $\mathrm{Fe}-\mathrm{Zn}$ $\mathrm{Cu}(\mathrm{Ru})_{3}-\mathrm{K}_{6}$ from the point view of promoter addition sequence. Aqueous solutions of $\mathrm{Cu}\left(\mathrm{NO}_{3}\right)_{2}$ and $\mathrm{Ru}(\mathrm{NO})\left(\mathrm{NO}_{3}\right)_{\mathrm{x}}(\mathrm{OH})_{\mathrm{y}}$ were used as the source of $\mathrm{Cu}$ and $\mathrm{Ru}$ promoters. The $\mathrm{pH}$ values of the aqueous solutions of $\mathrm{Cu}$ and $\mathrm{Ru}$ complexes were 3.0 and 0.3 , respectively. In the case of $\mathrm{Fe}-\mathrm{Zn}-\mathrm{Cu}_{3}-\mathrm{K}_{6}$ and $\mathrm{Fe}-\mathrm{Zn}-\mathrm{Ru}_{3}-\mathrm{K}_{6}$ samples with high FTS activity, $\mathrm{Cu}$ or Ru precursors were loaded onto $\mathrm{Fe}-\mathrm{Zn}$ oxide and then the samples were treated at $543 \mathrm{~K}$ before $\mathrm{K}_{2} \mathrm{CO}_{3}$ addition. In contrast, $\mathrm{Fe}-\mathrm{Zn}-\mathrm{K}_{6}-\mathrm{Cu}_{3}$ and $\mathrm{Fe}-\mathrm{Zn}-\mathrm{K}_{6}-\mathrm{Ru}_{3}$ samples, with lower FTS activity were obtained by the addition of $\mathrm{K}_{2} \mathrm{CO}_{3}$ followed by impregnation with $\mathrm{Cu}$ or $\mathrm{Ru}$ precursors. In the latter protocols, the acidic solutions containing $\mathrm{Cu}$ and $\mathrm{Ru}$ complexes, unstable species in basic media, were added to Fe- $\mathrm{Zn}$ oxide and $\mathrm{K}_{2} \mathrm{CO}_{3}$ particles on the surface of Fe- $\mathrm{Zn}$ oxide. The neutralization reaction of acidic species and $\mathrm{K}_{2} \mathrm{CO}_{3}$ would then result from the addition of metal nitrate solutions, suggesting that these reactions caused the rapid precipitation of $\mathrm{Cu}\left(\mathrm{NO}_{3}\right)_{2}$ and $\mathrm{Ru}(\mathrm{NO})\left(\mathrm{NO}_{3}\right)_{\mathrm{x}}(\mathrm{OH})_{y}$ complexes to form large hydroxide crystallites, while $\mathrm{K}_{2} \mathrm{CO}_{3}$ is converted to $\mathrm{KNO}_{3}$. Consequently, the particles of precipitated $\mathrm{Cu}$ and $\mathrm{Ru}$ hydroxides on the surface of Fe-Zn oxides would become larger and more heterogeneous on the surface during rapid precipitation compared to those promoted without neutralization. This low dispersion of promoters on the surface would lead to unfavorable FTS performance (higher $\mathrm{CH}_{4}$, lower $\mathrm{C}_{5+}$ selectivity and the decrease of FTS rates) on Fe- $\mathrm{Zn}-\mathrm{K}_{6}-\mathrm{Cu}_{3}$ and $\mathrm{Fe}-\mathrm{Zn}-\mathrm{K}_{6}-\mathrm{Ru}_{3}$ 
samples, because of poor contacting between promoters and the oxide precursors on which they act.

\subsection{Effect of $\mathrm{H}_{2} / \mathrm{CO}$ ratio on the Fisher-Tropsch synthesis rate and selectivity $\left(\mathrm{H}_{2} / \mathrm{CO}=1\right.$ versus $\mathrm{H}_{2} / \mathrm{CO}=2$ ).}

The Fe-based catalyst promoted with $\mathrm{K}$ and $\mathrm{Cu}\left(\mathrm{Fe}-\mathrm{Zn}-\mathrm{Cu}_{3}-\mathrm{K}_{6}\right)$ showed the highest $\mathrm{CO}$ conversion rates with sub-stoichiometric synthesis gas streams $\left(\mathrm{H}_{2} / \mathrm{CO}=1\right)$. We compare here the FT performance of prepared iron-based catalyst under stoichiometric synthesis gas $\left(\mathrm{H}_{2} / \mathrm{CO}=2\right)$ to that in hydrogen-poor reactants $\left(\mathrm{H}_{2} / \mathrm{CO}=1\right)$. The selectivities and steady-state FTS rates on $\mathrm{Fe}-\mathrm{Zn}-\mathrm{Cu}_{3}-\mathrm{K}_{6}$ are shown in Figure 1 as a function of $\mathrm{CO}$ conversion, varied by changes in space veloscity. These data were obtained by changing the $\mathrm{CO}$ space velocity at constant temperature $(508 \pm 0.5 \mathrm{~K})$. Stoichiometric synthesis gas led to lower $\mathrm{CO}_{2}$ selectivities and higher hydrocarbon formation rates, but also to slightly lighter products (higher $\mathrm{CH}_{4}$, a little lower $\mathrm{C}_{5+}$ selectivity; by 2-5\%; data not shown) and lower olefin content.
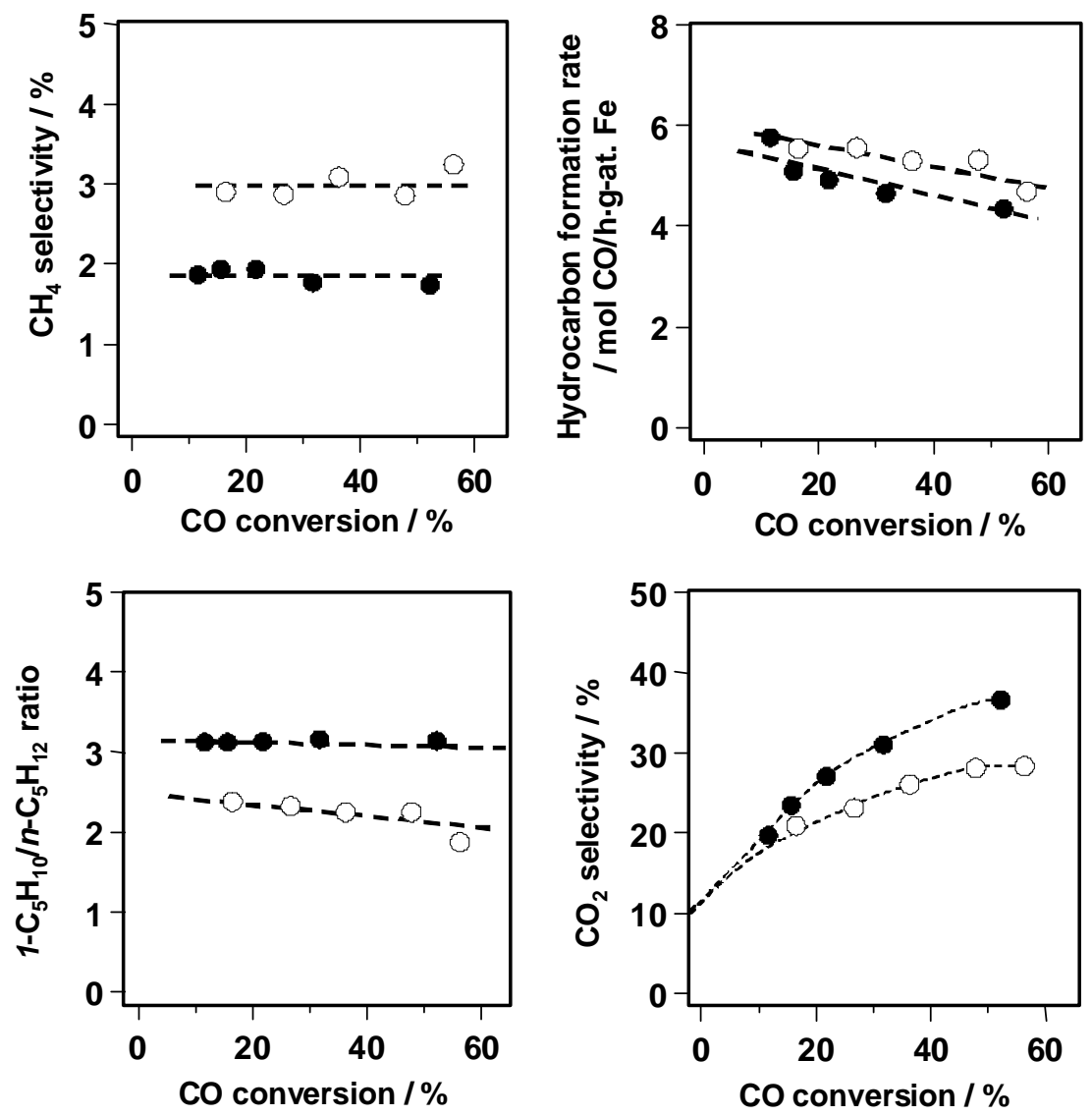

Figure 1.1. Steady state FTS rates and selectivities on $\mathrm{Fe}-\mathrm{Zn}-\mathrm{Cu}_{3}-\mathrm{K}_{6}$ catalyst as a function of $\mathrm{CO}$ conversion under synthesis gas stream with $\mathrm{H}_{2} / \mathrm{CO}=1$ (closed circles) and $\mathrm{H}_{2} / \mathrm{CO}=2$ (open circles) at $508 \mathrm{~K}$ and $2.14 \mathrm{MPa}$.

Fe-based catalysts are able to reject $\mathrm{O}$-atoms from $\mathrm{CO}$ as both $\mathrm{H}_{2} \mathrm{O}$ and $\mathrm{CO}_{2}$. Therefore, $\mathrm{H}_{2} \mathrm{O}$ and $\mathrm{CO}_{2}$ both form as primary FTS products on Fe-based catalysts:

$$
\begin{aligned}
2 \mathrm{H}_{2}+\mathrm{CO} & \rightarrow\left(-\mathrm{CH}_{2-}\right)_{\mathrm{n}}+\mathrm{H}_{2} \mathrm{O} \\
\mathrm{H}_{2}+2 \mathrm{CO} & \rightarrow\left(-\mathrm{CH}_{2}-\right)_{\mathrm{n}}+\mathrm{CO}_{2}
\end{aligned}
$$


The $\mathrm{H}_{2} \mathrm{O}$ formed as a primary product during FTS reactions can react with $\mathrm{CO}$ to give $\mathrm{CO}_{2}$ via secondary water-gas shift (WGS) reactions:

$$
\mathrm{CO}+\mathrm{H}_{2} \mathrm{O} \rightarrow \mathrm{CO}_{2}+\mathrm{H}_{2}
$$

O-atom rejection to form $\mathrm{H}_{2} \mathrm{O}$ seems to be the favorable pathway under stoichiometric synthesis gas stream [7], while O-atom rejection to form $\mathrm{CO}_{2}$ would become an important pathway in CO-rich synthesis gas streams. WGS reactions also become an important pathway with increasing $\mathrm{H}_{2} \mathrm{O}$ concentration for all synthesis gas stoichiometries. As shown in Figure 1, $\mathrm{CO}_{2}$ selectivities increased with increasing $\mathrm{CO}$ conversion for both sub-stoichiometric and stoichiometric synthesis gas streams. The local slopes of $\mathrm{CO}_{2}$ selectivities vs. $\mathrm{CO}$ conversion (or residence time) reflect the contributions of water-gas shift reactions to $\mathrm{CO}_{2}$ formation selectivities [7]. Therefore, the larger local slopes of $\mathrm{CO}_{2}$ selectivities with sub-stoichiometric reactants indicate that low $\mathrm{H}_{2} / \mathrm{CO}$ ratio favor secondary WGS rates. In contrast, the extrapolated y-intercepts in Figure $1 \mathrm{~b}$ are almost same in both cases, suggesting that different $\mathrm{H}_{2} / \mathrm{CO}$ ratio led to no significant change in the relative rates of removal of chemisorbed $\mathrm{O}$ atoms using $\mathrm{CO}$ to form $\mathrm{CO}_{2}$. Therefore, the decrease of $\mathrm{H}_{2} / \mathrm{CO}$ ratio led to strong contribution of WGS reaction to FTS reaction, suggesting that $\mathrm{Fe}-\mathrm{Zn}-\mathrm{Cu}_{3}-\mathrm{K}_{6}$ provides active sites for WGS reaction and allows the efficient use of synthesis gas with sub-stoichiometric $\mathrm{H}_{2} / \mathrm{CO}$ ratios by using the majority $\mathrm{CO}$ species as the oxygen rejection co-reactant.

\subsection{Catalytic stability of Fe-Zn-Cu$-\mathrm{K}_{6}$ materials.}

The Fisher-Tropsch synthesis was carried out on optimal $\mathrm{Fe}-\mathrm{Zn}-\mathrm{Cu}_{3}-\mathrm{K}_{6}$ catalysts at $508 \mathrm{~K}$ and 2.14 MPa under synthesis gas stream $\left(5.0 \mathrm{NL} \mathrm{h}^{-1} \mathrm{~g}_{\text {cat }}{ }^{-1}\right)$ with $\mathrm{H}_{2} / \mathrm{CO}=1$ for $240 \mathrm{~h}$ in order to examine the stability of this catalyst. Figure 1.2 shows the dependence of $\mathrm{CO}$ conversion and hydrocarbon formation rate with time on stream. A more detailed summary of the catalytic performance is shown in Table 3. The total amount of the formed hydrocarbon with $0.4 \mathrm{~g} \mathrm{Fe}-$ $\mathrm{Zn}-\mathrm{Cu}_{3}-\mathrm{K}_{6}$ catalyst was estimated to be $\sim 16 \mathrm{~kg}$ for $240 \mathrm{~h}$. The rates of $\mathrm{CO}$ conversion and hydrocarbon formation on $\mathrm{Fe}-\mathrm{Zn}-\mathrm{Cu}_{3}-\mathrm{K}_{6}$ decreased rapidly during an initial period $(\sim 9 \mathrm{~h})$. During this initial period, the rapid decrease of FTS performance reflects a decrease in surface area as a consequence of the oxide-carbide interconversions.

After this initial period, the deactivation of the catalyst became slower on $\mathrm{Fe}-\mathrm{Zn}-\mathrm{Cu}_{3}-\mathrm{K}_{6}$. The hydrocarbon formation rates and FTS performance obtained after the initial deactivation were reported as steady-state rates and FTS performance in previous sections. The hydrocarbon formation rates, $\mathrm{CO}_{2}, \mathrm{C}_{5+}$ selectivities and olefin/paraffin ratio decreased gradually during 240 $\mathrm{h}$, while the amount of the light products formed on the catalyst increased gradually with increasing time on stream. Although the catalytic deactivation would be related to the formation of the inactive species such as carbon on the surface, the sequential changes of FTS performance suggest that promoters become increasingly unavailable at active surfaces. It appears that the small amounts of catalyst granules and promoters are removed out of the reactor by the synthesis gas stream. This is supported by the fact that the wax collected after the reactor was dark, suggesting the presence of Fe carbides.

The procedure proposed in the previous section for the addition of promoters can result in $\mathrm{Fe}-\mathrm{Zn}-\mathrm{Cu}_{3}-\mathrm{K}_{6}$ and $\mathrm{Fe}-\mathrm{Zn}-\mathrm{Ru}_{3}-\mathrm{K}_{6}$ catalysts with a superior FTS catalytic rates compared to Fe$\mathrm{Zn}-\mathrm{K}_{6}-\mathrm{Cu}_{3}$ and $\mathrm{Fe}-\mathrm{Zn}-\mathrm{K}_{6}-\mathrm{Ru}_{3}$ catalysts prepared by conventional procedures. We have found that the $\mathrm{Fe}-\mathrm{Zn}-\mathrm{Cu}_{3}-\mathrm{K}_{6}$ catalyst showed the highest FTS performance among all the catalysts studied here. 


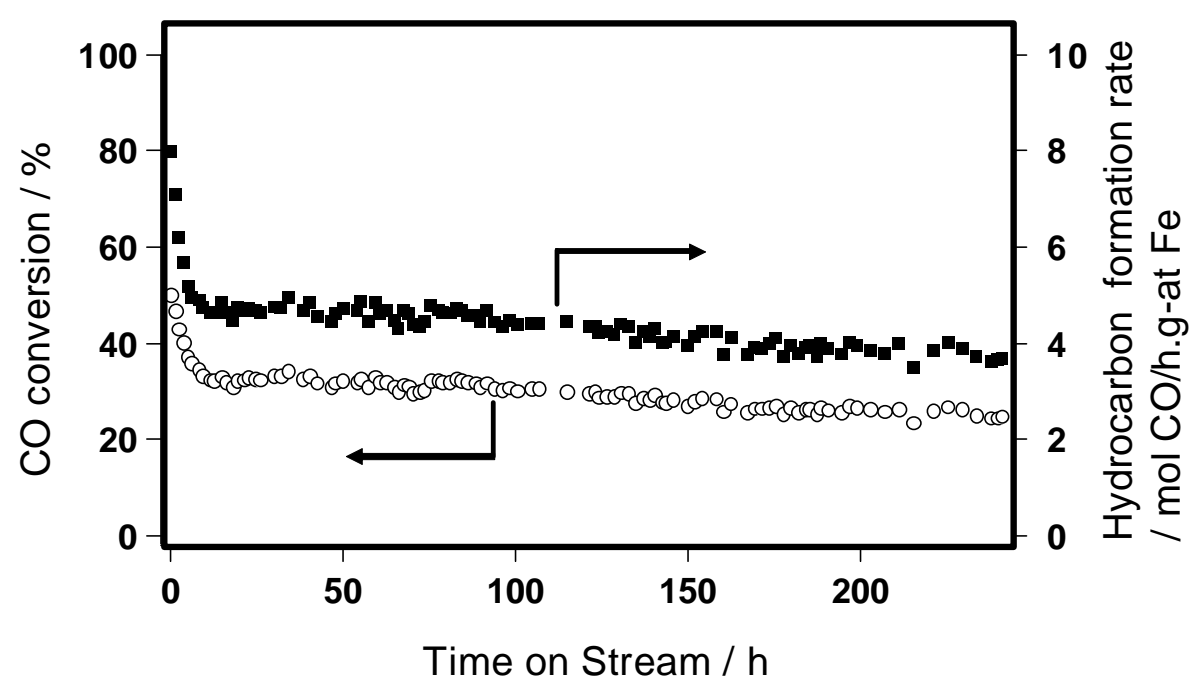

Figure 1.2. $\mathrm{CO}$ conversions and hydrocarbon formation rates with time on stream $\left(\mathrm{H}_{2} / \mathrm{CO}=1\right.$, $\mathrm{SV}=5.0 \mathrm{NL} /$ h.g-cat.) at $508 \mathrm{~K}$ and $2.14 \mathrm{MPa}$.

Table 1.3. FTS performance in sequence FTS reaction at $508 \mathrm{~K}$ and $2.14 \mathrm{MPa}$ with synthesis gas $\left(\mathrm{H}_{2} / \mathrm{CO}=1, \mathrm{SV}=5.0 \mathrm{NL} \mathrm{h}^{-1} \mathrm{~g}_{\text {cat }}{ }^{-1}\right)$.

\begin{tabular}{lcccccccc}
\hline Time on Stream (h) & 16 & 60 & 86 & 107 & 162 & 185 & 221 & 240 \\
\hline $\begin{array}{l}\text { CO conversion rate } \\
\text { (mol CO/h.g-at.Fe) }\end{array}$ & 6.8 & 6.8 & 6.8 & 6.5 & 5.9 & 5.6 & 5.5 & 5.2 \\
$\begin{array}{l}\text { Hydrocarbon formation rate } \\
\text { (mol CO/h.g-at.Fe) }\end{array}$ & 4.6 & 4.6 & 4.6 & 4.4 & 4.1 & 4.0 & 3.9 & 3.7 \\
CO conversion (\%) & 31.9 & 31.9 & 31.9 & 30.7 & 27.6 & 26.3 & 26.0 & 24.6 \\
$\mathrm{CO}_{2}$ selectivity (\%) & 31.5 & 32.0 & 32.1 & 32.2 & 29.7 & 29.1 & 30.1 & 30.0 \\
$\mathrm{CH}_{4}$ selectivity (\%) & 2.0 & 2.2 & 2.3 & 2.4 & 2.4 & 2.4 & 2.5 & 2.5 \\
$\mathrm{C}_{5}^{+}$selectivity (\%) & 88.6 & 87.4 & 86.6 & 87.1 & 86.7 & 86.7 & 86.1 & 85.9 \\
$1-\mathrm{C}_{5} \mathrm{H}_{10} / n-\mathrm{C}_{5} \mathrm{H}_{12}$ ratio & 3.1 & 3.1 & 3.1 & 3.0 & 2.9 & 2.9 & 2.9 & 2.9 \\
$1-\mathrm{C}_{10} \mathrm{H}_{20} / n-\mathrm{C}_{10} \mathrm{H}_{22}$ ratio & 1.6 & 1.6 & 1.7 & 1.5 & 1.5 & 1.4 & 1.5 & 1.5 \\
\hline
\end{tabular}

${ }^{\mathrm{a}} \mathrm{CH}_{4}, \mathrm{C}_{5+}$, and $\mathrm{C}_{2}-\mathrm{C}_{4}$ selectivities are reported on a $\mathrm{CO}_{2}$-free basis.

We compare here FTS reaction rates and selectivities on a $\mathrm{Fe}-\mathrm{Zn}-\mathrm{Cu}_{3}-\mathrm{K}_{6}$ catalyst with those on previously reported Fe-based catalysts. $\mathrm{Fe}-\mathrm{Zn}-\mathrm{Cu}_{3}-\mathrm{K}_{6}$ samples are compared with the most active reported Fe-based catalysts in Table 1.4 at relatively high $\mathrm{CO}$ conversions. These Fischer-Tropsch synthesis rates and selectivities were measured in fixed-bed reactor. Low $\mathrm{H}_{2} / \mathrm{CO}$ reactant $\left(\mathrm{H}_{2} / \mathrm{CO}=1\right)$ led to low hydrocarbon productivities relative to those with stoichiometric reactants $\left(\mathrm{H}_{2} / \mathrm{CO}=2\right)$. Fe- $\mathrm{Zn}-\mathrm{Cu}_{3}-\mathrm{K}_{6}$ showed the highest hydrocarbon productivity for FTS reaction among all reported catalysts, even though previously reported catalysts were tested at higher temperatures. 
Table 1.4. Steady-state FTS performance of various Fe-based catalysts in a fixed-bed reactor.

\begin{tabular}{|c|c|c|c|c|}
\hline & \multicolumn{2}{|c|}{$\begin{array}{l}\mathrm{FeZnCu}_{3} \mathrm{~K}_{6} \\
\text { This work }\end{array}$} & $\begin{array}{c}\mathrm{FePtK} / \mathrm{SiO}_{2}{ }^{\mathrm{a}} \\
\text { (8) }\end{array}$ & $\begin{array}{c}\mathrm{Fe} / \mathrm{Cu} / \mathrm{K}^{\mathrm{b}} \\
(9)\end{array}$ \\
\hline Temperature (K) & 508 & 508 & 543 & 533 \\
\hline Pressure (MPa) & 2.14 & 2.14 & 1.14 & 1.5 \\
\hline $\mathrm{H}_{2} / \mathrm{CO}$ ratio & 1.0 & 2.0 & 1.0 & 1.0 \\
\hline $\operatorname{GHSV}\left(\mathrm{NL} \mathrm{h}^{-1} \mathrm{~g}_{\mathrm{cat}^{-1}}\right)$ & 6.8 & 8.9 & 1.92 & 4.0 \\
\hline Syngas conv. (\%) & 53.4 & 51.3 & 53.5 & 54.8 \\
\hline $\mathrm{CO}_{2}$ selectivity $(\%)$ & 36.6 & 28.1 & 39.7 & 45.0 \\
\hline $\begin{array}{l}\text { HC productivity } \\
\left(\mathrm{g} \mathrm{h}^{-1} \mathrm{~g}_{\text {cat }}{ }^{-1}\right)\end{array}$ & 0.65 & 0.79 & 0.1 & 0.43 \\
\hline
\end{tabular}

FTS reaction rates and selectivities on $\mathrm{Fe}-\mathrm{Zn}-\mathrm{Cu}_{3}-\mathrm{K}_{6}$ samples in fixed-bed reactors are also compared with FTS performance reported in slurry reactor in Table 1.5 [10-12]. FTS reaction rates and selectivities on $\mathrm{Fe}-\mathrm{Zn}-\mathrm{Cu}_{3}-\mathrm{K}_{6}$ samples in fixed-bed reactors were measured at two different conditions, (i) at $508 \mathrm{~K}, 2.14 \mathrm{MPa}$, and (ii) at $543 \mathrm{~K}, 1.31 \mathrm{MPa}$. Higher temperatures led to higher hydrocarbon productivities even at the lower reactant pressures used. The hydrocarbon synthesis productivity on $\mathrm{Fe}-\mathrm{Zn}-\mathrm{Cu}_{3}-\mathrm{K}_{6}$ under synthesis gas stream with $\mathrm{H}_{2} / \mathrm{CO}=1.0$ at $543 \mathrm{~K}$ and $1.31 \mathrm{MPa}$ are about 2 times larger than those reported on $\mathrm{Fe}-\mathrm{Si}_{4.6}-\mathrm{K}_{1.4}$, even though $\mathrm{Fe}-\mathrm{Zn}-\mathrm{Cu}_{3}-\mathrm{K}_{6}$ catalysts were tested under synthesis gas stream with lower $\mathrm{H}_{2} / \mathrm{CO}$ ratio $\left(\mathrm{H}_{2} / \mathrm{CO}=1.0\right.$ vs. 1.7$)$.

Our additional study of synthesis, promotion and activation protocols to increase the density of FTS active site has led to additional improvements in hydrocarbon synthesis productivities. We have reported here the effects of promoters $(\mathrm{K}, \mathrm{Cu}, \mathrm{Ru})$ on Fisher-Tropsch synthesis rates and selectivities, as well as the effect of two different procedures for promoter addition. The $\mathrm{FeZnCu}_{3} \mathrm{~K}_{6}$ catalysts obtained by the efforts carried out as part of this project have led to unprecedented FTS reaction rates and $\mathrm{C}_{5+}$ selectivities for hydrogen-poor synthesis gas $\left(\mathrm{H}_{2} / \mathrm{CO}=1\right)$ reactants derived from emerging coal and biomass sources. 
Table 1.5. Steady-state FTS performance of various Fe-based catalysts using natural gasderived synthesis gas $\left(\mathrm{H}_{2} / \mathrm{CO}=1.0-1.7\right)$.

\begin{tabular}{|c|c|c|c|c|c|}
\hline & \multicolumn{2}{|c|}{$\begin{array}{c}\mathrm{FeZnCu}_{3} \mathrm{~K}_{6} \\
\text { This work }\end{array}$} & $\begin{array}{c}\mathrm{FeK} / \mathrm{SiO}_{2}{ }^{\mathrm{a}} \\
\text { (10) }\end{array}$ & $\begin{array}{c}\mathrm{FeCuK} / \mathrm{SiO}_{2}{ }^{\mathrm{b}} \\
\text { (11) }\end{array}$ & $\begin{array}{c}\mathrm{FeCuK} / \mathrm{SiO}_{2}{ }^{\mathrm{c}} \\
\text { (12) }\end{array}$ \\
\hline Reactor Type & \multicolumn{2}{|c|}{ Fixed-bed } & Slurry & Slurry & Slurry \\
\hline Temperature (K) & 508 & 543 & 543 & 533 & 523 \\
\hline Pressure (MPa) & 2.14 & 1.31 & 1.31 & 2.00 & 1.48 \\
\hline $\mathrm{H}_{2} / \mathrm{CO}$ ratio & 1.0 & 1.0 & 1.7 & 0.7 & 0.7 \\
\hline Syngas conv. (\%) & 53.4 & 43.3 & 50.0 & 67.0 & 56.1 \\
\hline $\mathrm{CO}_{2}$ selectivity $(\%)$ & 36.6 & 41.1 & 40.0 & - & 41.1 \\
\hline $\begin{array}{l}\text { HC productivity } \\
\left(\mathrm{g} \mathrm{h}^{-1} \mathrm{~g}_{\mathrm{cat}}{ }^{-1}\right)\end{array}$ & 0.65 & 1.91 & 1.00 & 0.16 & 0.37 \\
\hline
\end{tabular}

a $100 \mathrm{Fe} / 4.6 \mathrm{Si} / 1.4 \mathrm{~K}$

b $100 \mathrm{Fe} / 5 \mathrm{Cu} / 3 \mathrm{~K} / 8 \mathrm{SiO}_{2}$

c $100 \mathrm{Fe} / 4.3 \mathrm{Cu} / 4.1 \mathrm{~K} / 25 \mathrm{SiO}_{2}$

\section{Structural evolution and spectroscopic studies of site requirements in Fe catalyzed Fischer-Tropsch synthesis with hydrogen-poor synthesis gas feedstocks.}

Iron-based catalysts for the Fischer-Tropsch synthesis form the active sites required by specific catalyst activation processes that are critical to their rate, stability, and selectivity. Several phases of Iron have been found to co-exist during FTS reactions; these include metallic $\mathrm{Fe}(\alpha-\mathrm{Fe}), \mathrm{Fe}$ oxides, and $\mathrm{Fe}$ carbides. Fe catalysts are generally activated above reaction temperatures $(>500 \mathrm{~K})$ in synthesis gas or $\mathrm{CO}$ to form the required active phases.

We have characterized the catalyst structural changes and active phases formed and their catalytic behavior during activation process to evaluate their influence on FTS reactions. The structural change of catalysts and catalytic behavior during activation processes were probed using a combination of X-ray absorption spectroscopy and isothermal transient rates measured from effluent concentrations determined by mass spectrometry and gas chromatography. We report here (i) structural evolution of $\mathrm{Fe}-\mathrm{Zn}$ oxide promoted with $\mathrm{K}$ and $\mathrm{Cu}$, and (ii) hydrocarbon and $\mathrm{CH}_{4}$ formation rates during activation procedures at various temperature and $\mathrm{H}_{2} / \mathrm{CO}$ ratios. On the basis of the obtained results, we suggest that lower reactor temperature can be sufficient to activate catalysts and to maintain high surface areas and site densities and this lead to excellent FTS performance.

\subsection{Methodology.}

2.1.1. Temperature-programmed reaction and isothermal transient measurements FischerTropsch synthesis rates.

Hydrocarbon, water, and carbon dioxide formation rates during contact with synthesis gas were measured using on-line mass spectrometric analysis. Intensities of 2, 15, 18, 28, 40 and $44 \mathrm{amu}$ were used to measure $\mathrm{H}_{2}, \mathrm{CH}_{4}, \mathrm{H}_{2} \mathrm{O}, \mathrm{CO}, \mathrm{Ar}$, and $\mathrm{CO}_{2}$ concentrations, respectively. 
Samples $(0.2 \mathrm{~g})$ were diluted with quartz granules $(2.0 \mathrm{~g})$ and placed within a quartz microreactor. The samples were treated in $\mathrm{He}\left(108 \mathrm{~mol} \mathrm{~h}^{-1} \mathrm{~g}\right.$-at Fe $\left.\mathrm{Fe}^{-1}\right)$ at $573 \mathrm{~K}$ for $1 \mathrm{~h}$, and then cooled to the reaction temperatures before contact with synthesis gas. Temperatureprogrammed reaction measurements were carried out by increasing the temperature from 300 $\mathrm{K}$ to $673 \mathrm{~K}$ at a rate of $5 \mathrm{~K} / \mathrm{min}$ in flowing synthesis gas. In isothermal transient experiments, the $\mathrm{He}$ stream was switched to a flow of synthesis gas $\left(\mathrm{H}_{2} / \mathrm{CO} / \mathrm{Ar}, 108 \mathrm{~mol} \mathrm{~h}^{-1} \mathrm{~g}\right.$-at $\left.\mathrm{Fe}^{-1}\right)$ at various temperatures. After isothermal transient experiments, the samples were cooled to 508 $\mathrm{K}$ and $\mathrm{CH}_{4}$ formation rates were measured in flowing synthesis gas $\left(\mathrm{H}_{2} / \mathrm{CO} / \mathrm{Ar}=0.46 / 0.46 / 0.08\right.$, $108 \mathrm{~mol} \mathrm{~h}^{-1} \mathrm{~g}$-at $\mathrm{Fe}^{-1}$ ) in order to evaluate catalyst performance. BET surface area measurements were carried out after measurements of $\mathrm{CH}_{4}$ formation rates at $508 \mathrm{~K}$, and $\mathrm{He}$ purge $\left(108 \mathrm{~mol} \mathrm{~h}^{-1} \mathrm{~g}\right.$-at $\left.\mathrm{Fe}^{-1}\right)$ at $573 \mathrm{~K}$ for $1 \mathrm{~h}$, quenching to ambient temperature, and passivation of the samples in flowing $5 \mathrm{vol} . \% \mathrm{O}_{2} / \mathrm{He}$ at ambient temperature. $\mathrm{N}_{2}$ physisorption measurements were performed at its normal boiling point $(77 \mathrm{~K})$ and surface areas were calculated using the BET method.

\subsubsection{X-Ray absorption spectroscopy.}

Fe K-edge X-ray absorption spectra were measured for $\mathrm{FeZnCu}_{3} \mathrm{~K}_{6}$ during its reduction and carburization in synthesis gas. $\mathrm{Fe}_{2} \mathrm{O}_{3}$ (Aldrich, \%), $\mathrm{Fe}_{3} \mathrm{O}_{4}$ (Alfa AESAR, 99.997 \%), and $\mathrm{FeO}$ (Alfa AESAR, $99.5 \%$ ), $\mathrm{Fe}_{3} \mathrm{C}$ were used as reference crystalline samples. The details of these XAS measurements have been described elsewhere [13]. All X-ray absorption spectra were measured at the Stanford Synchrotron Radiation Laboratory (SSRL). The storage ring was operated at $30-100 \mathrm{~mA}$ and $3.0 \mathrm{GeV}$ during the measurements. Two $\mathrm{Si}(111)$ crystals detuned by $20 \%$ in order to reject harmonics were used in the monochromator. The spectra were analyzed using WinXAS (version 2.1). Principal component analysis and linear combination methods were used in order to determine the structures present in each sample from spectral features in the near-edge region (6.9-7.4 keV). All samples used in spectroscopic measurements were diluted to $10 \mathrm{wt} \%$ Fe using graphite powder (Alfa, $99.9995 \%$ ), sieved to retain $180-250 \mu \mathrm{m}$ particles, and placed within an quartz capillary cell. The samples were treated in $\mathrm{He}\left(\mathrm{mol} \mathrm{h}^{-1} \mathrm{~g}\right.$-at $\left.\mathrm{Fe}^{-1}\right)$ at $543 \mathrm{~K}$ for $1 \mathrm{~h}$, and then cooled or heated to the reaction temperatures before contacting with synthesis gas.

\subsection{Catalytic behavior on iron based catalysts during the activation process.}

FTS rates and selectivities for Fe-Zn oxide, Fe- $\mathrm{Zn}-\mathrm{K}_{6}$, and $\mathrm{Fe}-\mathrm{Zn}-\mathrm{Cu}_{3}-\mathrm{K}_{6}$ catalysts were measured during isothermal activation processes $(543 \mathrm{~K})$ in order to evaluate the relationship between catalyst activation time and FTS performance. These isothermal activation processes were carried out after treating the samples in $\mathrm{He}\left(100 \mathrm{~cm}^{3} \mathrm{~min}^{-1}\right)$ at $573 \mathrm{~K}$ for $1 \mathrm{~h}$. Figure 2.1 shows the product formation rates on $\mathrm{Fe}-\mathrm{Zn}$ oxide, $\mathrm{Fe}-\mathrm{Zn}-\mathrm{K}_{6}$, and $\mathrm{Fe}-\mathrm{Zn}-\mathrm{Cu}_{3}-\mathrm{K}_{6}$ during activation process with hydrogen-poor synthesis gas reactant $\left(\mathrm{H}_{2} / \mathrm{CO}=1\right)$ at $543 \mathrm{~K}$. Methane and hydrocarbons were immediately formed on $\mathrm{Fe}-\mathrm{Zn}-\mathrm{Cu}_{3}-\mathrm{K}_{6}$ after contacting with synthesis gas, and these formation rates reached maximum values after $\sim 1.5 \mathrm{~h}$, respectively. This indicates that the active sites on $\mathrm{Fe}-\mathrm{Zn}-\mathrm{Cu}_{3}-\mathrm{K}_{6}$ for FTS reaction were formed immediately after contact with synthesis gas. The formation rates of methane and hydrocarbons over Fe-Zn oxide and $\mathrm{Fe}-\mathrm{Zn}-\mathrm{K}_{6}$ increased gradually with time on stream. Several iron phases, such as $\mathrm{Fe}_{3} \mathrm{O}_{4}$ and $\mathrm{Fe}_{3} \mathrm{C}$, have been postulated in the literature to be the active sites for hydrocarbon formation [14-16]. It seems that the formation of $\mathrm{Fe}_{3} \mathrm{O}_{4}$ and $\mathrm{Fe}$ carbide phases on $\mathrm{Fe}-\mathrm{Zn}$ oxide and $\mathrm{Fe}-\mathrm{Zn}$ $\mathrm{K}_{6}$ without $\mathrm{Cu}$ promoter took place slowly during the initial period $(2 \mathrm{~h})$, probably because of the $\mathrm{Zn}$ and $\mathrm{K}$ components inhibit the reduction of $\mathrm{Fe}_{2} \mathrm{O}_{3}$ [2]. After $15 \mathrm{~h}$ on stream, Fe- $\mathrm{Zn}$ oxide showed the highest $\mathrm{CH}_{4}$ formation rate on Fe-Zn oxide. In contrast, $\mathrm{C}_{5+}$ selectivities onr Fe-Zn$\mathrm{K}_{6}$ and $\mathrm{Fe}-\mathrm{Zn}-\mathrm{Cu}_{3}-\mathrm{K}_{6}$ were 91 and $89 \%$, and much higher than on Fe-Zn oxide (62 \%), as a result of the effects of the $\mathrm{K}$ promoter. 

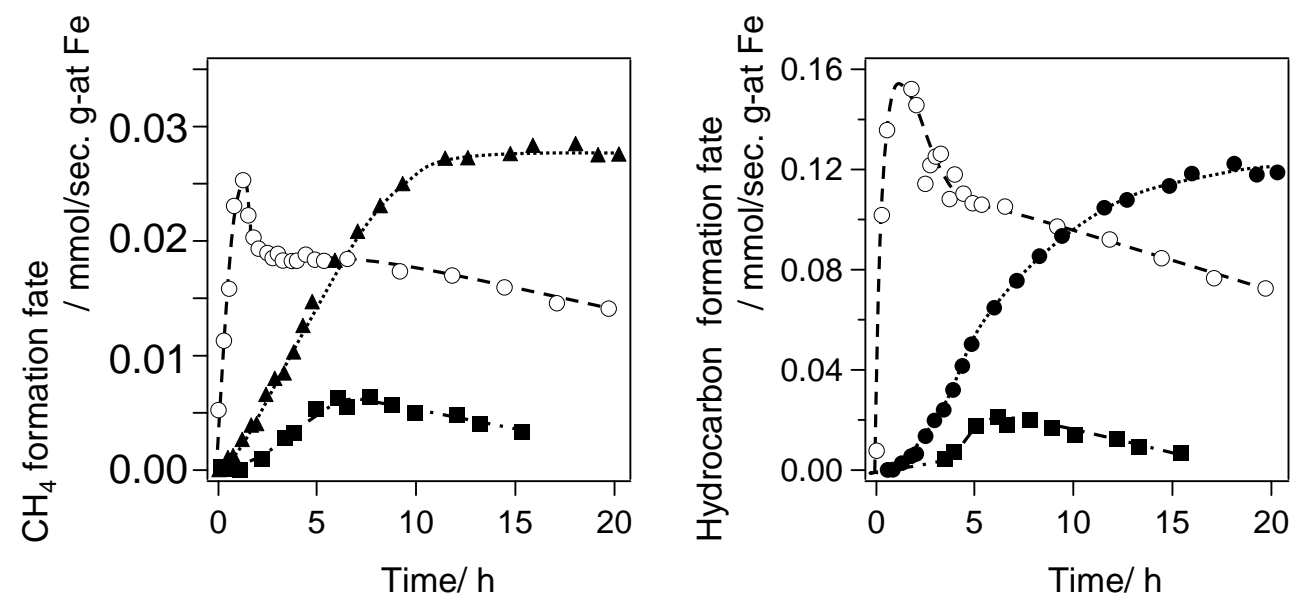

Figure 2.1. $\mathrm{CH}_{4}$ and hydrocarbon $\left(\mathrm{C}_{1}-\mathrm{C}_{9}\right)$ formation rates on iron-based catalysts during activation process. $\left(0.2 \mathrm{~g}\right.$ sample; $\mathrm{H}_{2} / \mathrm{CO}=1$, flow rate: $108 \mathrm{~mol} / \mathrm{h}$. g-atom $\mathrm{Fe}$, at $523 \mathrm{~K}$ and $0.1 \mathrm{MPa},(\circ) \mathrm{Fe}-\mathrm{Zn}-\mathrm{Cu}_{3}-\mathrm{K}_{6}$, (ם) Fe-Zn-K 6 , ( $\left.\mathbf{\Delta}\right) \mathrm{Fe}-\mathrm{Zn}$ oxide).

After contact with synthesis gas, $\mathrm{CH}_{4}$ and hydrocarbon formation rates reached maximum values at times that increased in the sequence Fe- $\mathrm{Zn}-\mathrm{Cu}_{3}-\mathrm{K}_{6}(1.5 \mathrm{~h}), \mathrm{Fe}-\mathrm{Zn}-\mathrm{K}_{6}(6 \mathrm{~h})$, and Fe- $\mathrm{Zn}$ $(15 \mathrm{~h})$. Previous studies using mass spectrometry have reported that steady state $\mathrm{CH}_{4}$ formation rates on both $\mathrm{Fe}-\mathrm{Zn}-\mathrm{K}_{4}$ and $\mathrm{Fe}-\mathrm{Zn}-\mathrm{K}_{4}-\mathrm{Cu}_{2}$ were attained after $1 \mathrm{~h}$ in contact with synthesis gas $\left(\mathrm{H}_{2} / \mathrm{CO}=2\right)$ and no detectable change was observed in $\mathrm{CH}_{4}$ formation rates up to $\sim 8 \mathrm{~h}$ [13]. Besides, the $\mathrm{CH}_{4}$ formation rates were $\sim 10$ times higher than the observed rates on $\mathrm{Fe}-\mathrm{Zn}-\mathrm{Cu}_{3}-$ $\mathrm{K}_{6}$ in this study, even though both catalysts gave similar FTS performance at $508 \mathrm{~K}, 2.14 \mathrm{MPa}$ and with stoichiometric synthesis gas $\left(\mathrm{H}_{2} / \mathrm{CO}=2\right)$, as described above. The origins of these differences remain unclear at this time and indicate that further investigations of the activation processes for $\mathrm{Fe}-\mathrm{Zn}-\mathrm{Cu}_{3}-\mathrm{K}_{6}$ in hydrogen-poor synthesis gas are required to establish the detailed effects of catalyst activation condition on FTS performance.

\subsection{Structural evolution studies by $X$-ray absorption spectroscopy and mass spectrometry.}

The structure and nature of iron oxide phases and the reaction products formed during the catalyst activation process were measured by X-ray absorption spectroscopy and mass spectrometry to explore in detail the structure and function of catalysts during activation. FTS rates on $\mathrm{Fe}-\mathrm{Zn}$ oxide, $\mathrm{Fe}-\mathrm{Zn}-\mathrm{K}_{6}$ and $\mathrm{Fe}-\mathrm{Zn}-\mathrm{Cu}_{3}-\mathrm{K}_{6}$ (shown in Figure 2.1) indicate that the catalytic activities on the different catalysts cannot be evaluated on the basis of $\mathrm{CH}_{4}$ formation rates alone because of the different FTS selectivities among these samples. However, the behavior of $\mathrm{CH}_{4}$ formation rate for a fixed catalyst can be related to its rate of hydrocarbon formation rate. Therefore, the catalytic activities were investigated on the basis of the $\mathrm{CH}_{4}$ formation rate accurately measured by mass spectrometry here.

\subsubsection{In situ structural evolution and products analysis during reactions on $\mathrm{Fe}-\mathrm{Zn}-\mathrm{Cu}_{3}-\mathrm{K}_{6}$ in hydrogen-poor synthesis gas.}

In situ Fe K-edge X-ray absorption spectroscopy was used to monitor the structural evolution of $\mathrm{Fe}-\mathrm{Zn}-\mathrm{Cu}_{3}-\mathrm{K}_{6}$ during activation and FTS reactions. Figure 2.2 shows Fe near-edge spectra for $\mathrm{Fe}-\mathrm{Zn}-\mathrm{Cu}_{3}-\mathrm{K}_{6}$ sample during exposure to sub-stoichiometric synthesis gas. Linear combination methods were used to calculate the relative abundance of $\mathrm{Fe}_{2} \mathrm{O}_{3}, \mathrm{Fe}_{3} \mathrm{O}_{4}$, and $\mathrm{FeC}_{\mathrm{x}}$ phases using near-edge spectral features. Figure 2.2 also shows the relative various phases required to describe measured near-edge spectra during reduction and carburization Fe- $\mathrm{Zn}$ $\mathrm{Cu}_{3}-\mathrm{K}_{6}$ under synthesis gas stream. The formation of $\mathrm{Fe}_{3} \mathrm{O}_{4}$ was observed above $373 \mathrm{~K}$, and 
then the relative abundance of $\mathrm{Fe}_{3} \mathrm{O}_{4}$ increased, particularly above $450 \mathrm{~K}$. The formation of $\mathrm{FeC}_{\mathrm{x}}$ converted from $\mathrm{Fe}_{3} \mathrm{O}_{4}$ was also observed above $400 \mathrm{~K}$. The relative abundance of $\mathrm{Fe}_{3} \mathrm{O}_{4}$ decreased above $560 \mathrm{~K}$, and then $\mathrm{FeC}_{\mathrm{x}}$ concentration reached $100 \%$ at $580 \mathrm{~K}$. The reductioncarburization reaction of the $\mathrm{Fe}_{2} \mathrm{O}_{3}$ phase stabilized by $\mathrm{ZnO}$ requires higher temperature than for pure $\mathrm{Fe}_{2} \mathrm{O}_{3}$ [2], while $\mathrm{Cu}$ decreases the temperature required for reduction-carburization reactions. The reduction and carburization of $\mathrm{Fe}-\mathrm{Zn}-\mathrm{Cu}_{3}-\mathrm{K}_{6}$ occurred at $\sim 80 \mathrm{~K}$ lower temperatures than that of pure $\mathrm{Fe}_{2} \mathrm{O}_{3}$ [13].
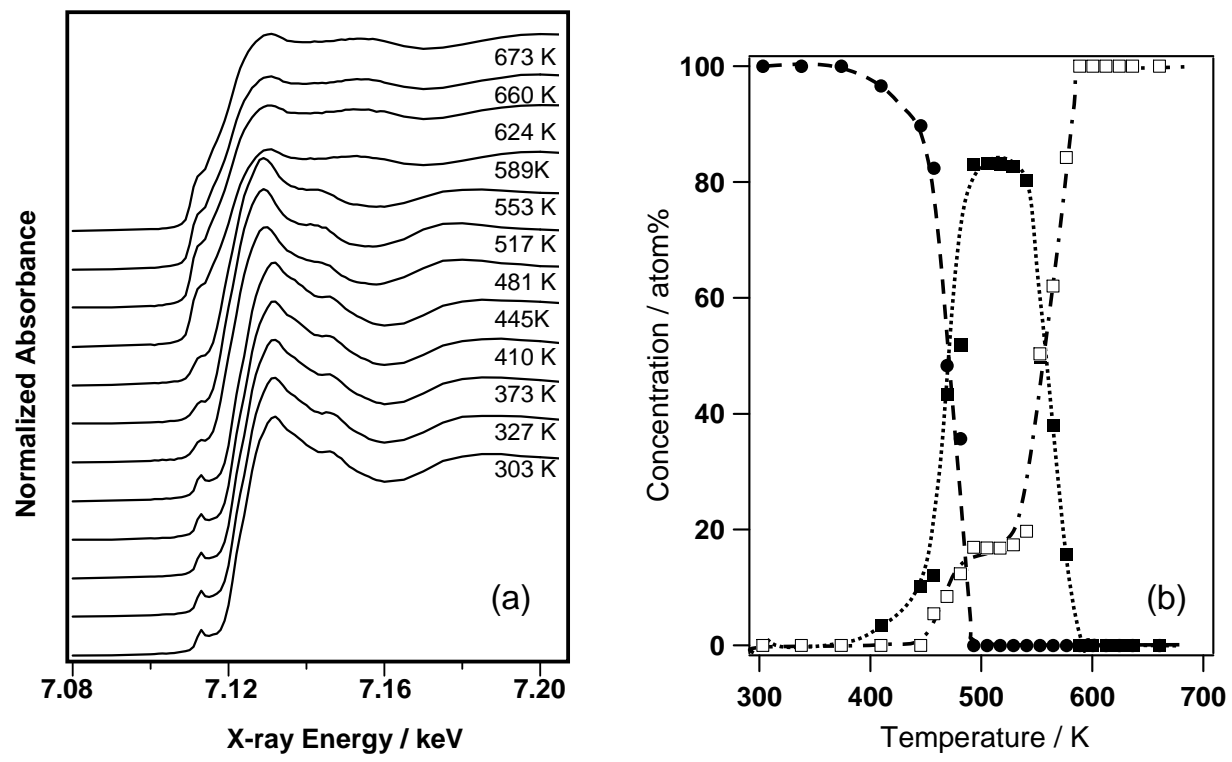

Figure 2.2. In situ Fe K-edge XANES spectra and structural evolution for $\mathrm{Fe}-\mathrm{Zn}-\mathrm{Cu}_{3}-\mathrm{K}_{6}$ sample in substoichiometric synthesis gas as a function of temperature. $\left(\mathrm{Fe}_{2} \mathrm{O}_{3}(\bullet), \mathrm{Fe}_{3} \mathrm{O}_{4}(\mathbf{\square})\right.$, $\mathrm{Fe}_{\mathrm{x}} \mathrm{C}(\square)$, synthesis gas $\left(\mathrm{H}_{2} / \mathrm{CO}=1\right)$ flow: $108 \mathrm{~mol} \mathrm{~h}^{-1}$ g-at Fe ${ }^{-1}, \mathrm{Fe}-\mathrm{Zn}-\mathrm{Cu}_{3}-\mathrm{K}_{6}: 1 \mathrm{mg}$, heating rate: $\left.5 \mathrm{~K} \mathrm{~min}^{-1}\right)$.

Product formation rates were measured on $\mathrm{Fe}-\mathrm{Zn}-\mathrm{Cu}_{3}-\mathrm{K}_{6}$ by transient FTS experiment at the standard reaction conditions $\left(\mathrm{H}_{2} / \mathrm{CO}=1,543 \mathrm{~K}, 0.1 \mathrm{MPa}\right)$ in Figure 2.2. Figure 2.3 shows the products formation rates of $\mathrm{CH}_{4}, \mathrm{H}_{2} \mathrm{O}$ and $\mathrm{CO}_{2}$ during reduction and carburization Fe- $\mathrm{Zn}$ $\mathrm{Cu}_{3}-\mathrm{K}_{6}$ under synthesis gas stream. The following reactions are observed during transient FTS experiment; (i) the removal of lattice oxygen atoms from $\mathrm{Fe}_{2} \mathrm{O}_{3}$ and $\mathrm{CuO}$ by $\mathrm{H}_{2}$ to form $\mathrm{H}_{2} \mathrm{O}$ or by $\mathrm{CO}$ to form $\mathrm{CO}_{2}$, (ii) the carburization of iron oxide by $\mathrm{CO}$ to form $\mathrm{CO}_{2}$, (iii) FTS reactions of $\mathrm{H}_{2}$ and $\mathrm{CO}$ to form hydrocarbons, $\mathrm{H}_{2} \mathrm{O}$ and $\mathrm{CO}_{2}$, (iv) water-gas shift reactions of $\mathrm{CO}$ and $\mathrm{H}_{2} \mathrm{O}$ to form $\mathrm{CO}_{2}$ and $\mathrm{H}_{2} \cdot \mathrm{CO}_{2}$ formation was observed above near ambient temperature, and then the rate increased with increasing temperature. $\mathrm{H}_{2} \mathrm{O}$ formation rate increased above $450 \mathrm{~K}$, while $\mathrm{CO}_{2}$ formation rate decreased concurrently. $\mathrm{CuO}$ is not reduced to $\mathrm{Cu}$ metal by $\mathrm{CO}$ or $\mathrm{H}_{2}$ at near ambient temperature [2]. Therefore, the $\mathrm{CO}_{2}$ formation below $\sim 450 \mathrm{~K}$ is assigned to the removal of lattice oxygen atoms by $\mathrm{CO}$ from $\mathrm{Fe}_{2} \mathrm{O}_{3}$ and $\alpha-\mathrm{FeOOH}$, as confirmed by X-ray diffractograms. $\mathrm{H}_{2} \mathrm{O}$ formation was observed at temperatures similar to those required for $\mathrm{CuO}$ reduction $(\sim 470 \mathrm{~K})$ [2]. $\mathrm{H}_{2} \mathrm{O}$ is formed both via reduction of $\mathrm{CuO}$ and of $\mathrm{Fe}$ oxide, the latter catalyzed by the presence of reduced $\mathrm{Cu}$ species, which dissociate $\mathrm{H}_{2}$ required for reduction processes. XAFS results also showed that the $\mathrm{Fe}_{3} \mathrm{O}_{4}$ formation rates increased above $470 \mathrm{~K}$ in Figure 2.1. The formed $\mathrm{Cu}$ metal promoted the reduction of $\mathrm{Fe}_{2} \mathrm{O}_{3}$ to $\mathrm{Fe}_{3} \mathrm{O}_{4}$ by $\mathrm{H}_{2}$ corresponding to the literature [2]. Above $540 \mathrm{~K}$, the $\mathrm{CO}_{2}$ formation rate and the relative abundance of $\mathrm{FeC}_{\mathrm{x}}$ formation dramatically increased, and $\mathrm{CH}_{4}$ formation was also observed concurrently. Therefore, this $\mathrm{CO}_{2}$ formation occurs via both FTS reactions and via 
carburization of iron oxide by $\mathrm{CO} . \mathrm{CO}_{2}$ formation rates above $\sim 620 \mathrm{~K}$ reflect FTS and WGS reactions, since $\mathrm{FeC}_{\mathrm{x}}$ concentrations have already reached $100 \%$ by these temperatures. $\mathrm{CH}_{4}$ formation rates increased with increasing amount of active sites and reaction temperature. Therefore, it appears that $\mathrm{CH}_{4}$ formation rates gradually increased with increasing temperature during this experiment. During transient FTS experiments, temperatures above $540 \mathrm{~K}$ were required to form $\mathrm{CH}_{4}$ on catalyst. In what follows, the catalyst structure and the products formed during catalytic activation process were investigated at temperatures between $508 \mathrm{~K}$ (reaction temperature) and $573 \mathrm{~K}$.

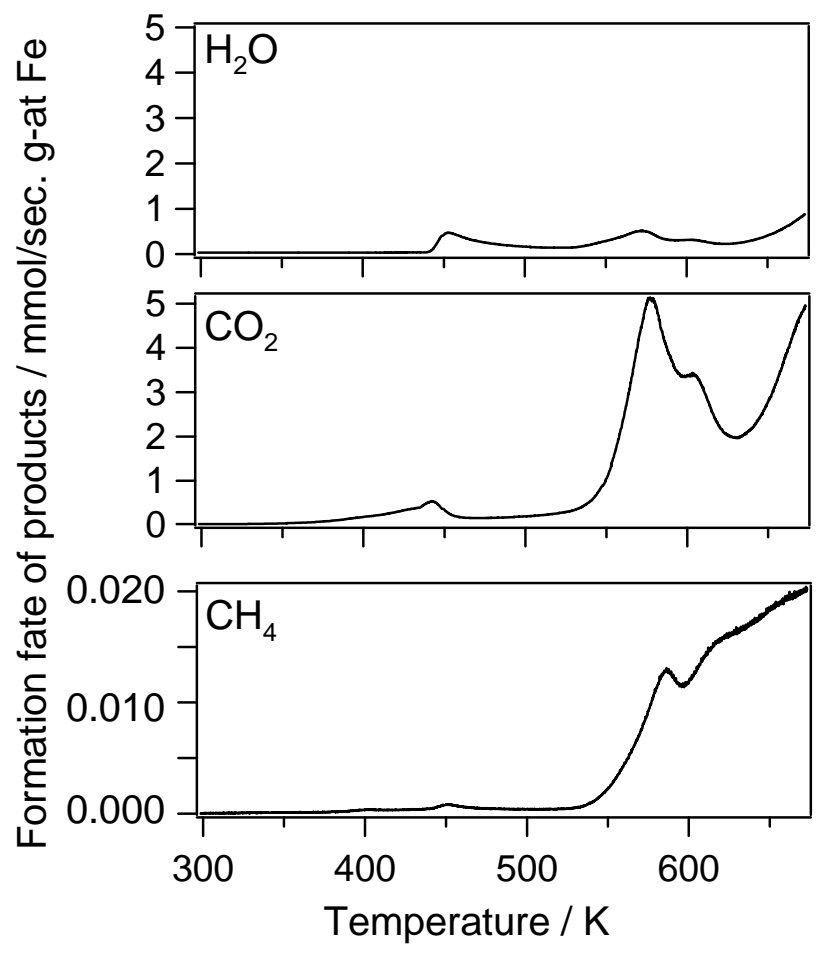

Figure 2.3. Product formation rates as a function of temperature during flow of substoichiometric synthesis gas. (synthesis gas flow: $108 \mathrm{~mol} \mathrm{~h}^{-1} \mathrm{~g}$-at Fe $\mathrm{F}^{-1}, \mathrm{Fe}-\mathrm{Zn}-\mathrm{Cu}_{3}-\mathrm{K}_{6}: 0.2 \mathrm{~g}$, heating rate: $5 \mathrm{~K} \mathrm{~min}^{-1}$ ).

\subsubsection{In-situ structural characterization and product evolution profiles during catalytic activation at various temperatures.}

Figure 2.4 shows formation rates for $\mathrm{CH}_{4}, \mathrm{H}_{2} \mathrm{O}$, and $\mathrm{CO}_{2}$ on $\mathrm{Fe}-\mathrm{Zn}-\mathrm{Cu}_{3}-\mathrm{K}_{6}$ with synthesis gas $\left(\mathrm{H}_{2} / \mathrm{CO}=1\right)$ reactants at $543 \mathrm{~K}$ and $0.1 \mathrm{MPa}$ as a function of time on stream. Figure 2.4 also shows the concentrations of the $\mathrm{Fe}_{2} \mathrm{O}_{3}, \mathrm{Fe}_{3} \mathrm{O}_{4}$, and $\mathrm{FeC}_{\mathrm{x}}$ phases measured concurrently from near-edge X-ray absorption spectra. During initial contact with synthesis gas (1-2 min), the catalyst temperature increased to $\sim 553 \mathrm{~K}$ because of exothermic events, but then stabilized at $\sim 543 \mathrm{~K}$. This initial transient exotherm led to the formation of some Fe metal near the reactor inlet. The previous work has estimated the number of active sites on catalysts after transient FTS experiments by using CO uptake measurement [1,13]. The estimation of the number of active site were, however, too inaccurate because of difficult deconvolution of the complex $\mathrm{CO}$ desorption spectra, as a result of the unintended formation of Fe metal near the top of the reactor. As a result, we were unable to estimate the number of active sites on the catalysts by using $\mathrm{CO}$ uptake measurements. Instead, we have used $\mathrm{CH}_{4}$ formation rate measured at $508 \mathrm{~K}, 0.1 \mathrm{MPa}$, and synthesis gas with $\mathrm{H}_{2} / \mathrm{CO}$ of 1 after catalyst activation as a 
measure of reactivity and of active site density.

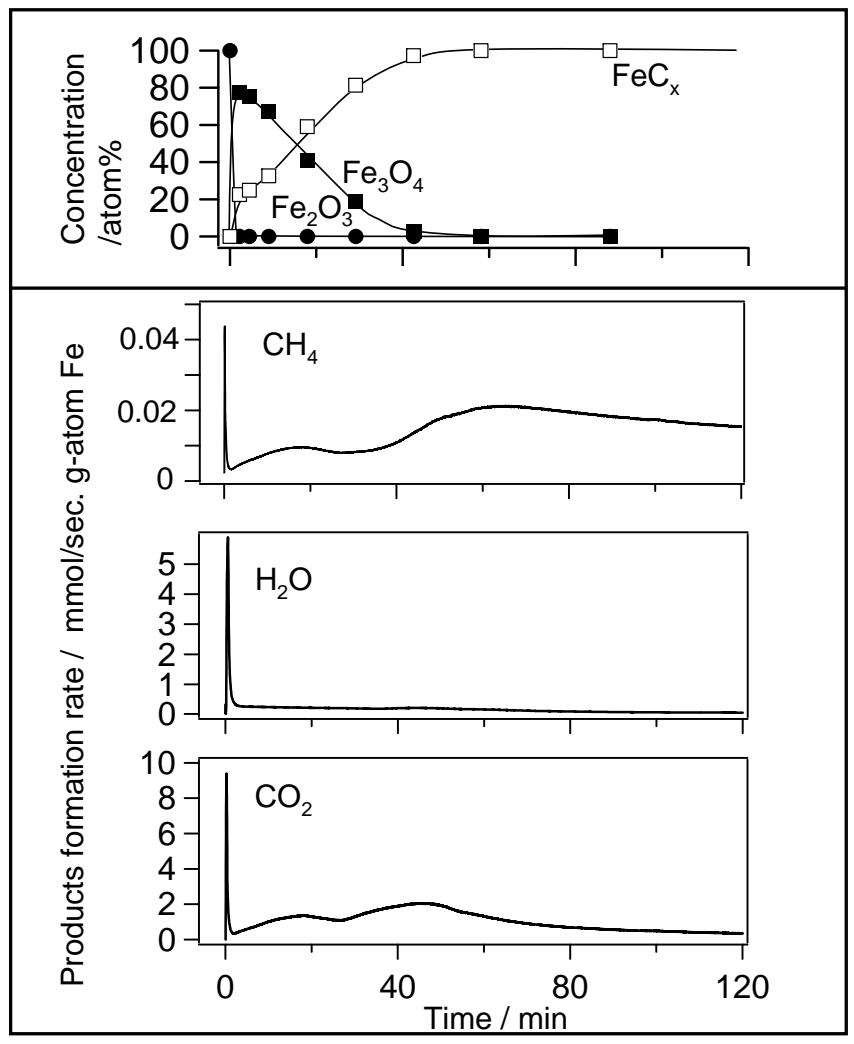

Figure 2.4. Structural evolution measured from X-ray absorption spectra (1 mg sample) and rate of formation of $\mathrm{CH}_{4}, \mathrm{H}_{2} \mathrm{O}$ and $\mathrm{CO}_{2}$ as a function of time on $\mathrm{Fe}-\mathrm{Zn}-\mathrm{Cu}_{3}-\mathrm{K}_{6}(0.2 \mathrm{~g}$ sample $)$ at $543 \mathrm{~K}$. (synthesis gas flow: $108 \mathrm{~mol} \mathrm{~h}^{-1} \mathrm{~g}$-at $\mathrm{Fe}^{-1}$ ).

X-ray absorption spectra for $\mathrm{Fe}-\mathrm{Zn}-\mathrm{Cu}_{3}-\mathrm{K}_{6}$ at $543 \mathrm{~K}$ changed with time on stream during contact with synthesis gas. Sharp peaks in $\mathrm{CH}_{4}, \mathrm{H}_{2} \mathrm{O}$ and $\mathrm{CO}_{2}$ formation rates were observed after the initial exposure $(\sim 1 \mathrm{~min})$ to synthesis gas at $543 \mathrm{~K}$. These sharp peaks were attributed to the reduction of $\mathrm{CuO}$ and $\mathrm{Fe}_{2} \mathrm{O}_{3}$ and the carburization of $\mathrm{Fe}_{3} \mathrm{O}_{4}$ at near-surface regions of oxide precursors; as a result, the reactor temperature increased up to $\sim 553 \mathrm{~K}$ because of the exotermic nature of the carburization of Fe oxides. The removal of lattice oxygen atoms from $\mathrm{CuO}$ to form $\mathrm{Cu}$ metal occurred during this period because the $\mathrm{CuO}$ deposited on catalyst surface is reduced easily to $\mathrm{Cu}$ metal at $\sim 540 \mathrm{~K}$. The amount of oxygen removed during this period was, however, larger than the amount of lattice oxygen in $\mathrm{CuO}$. X-ray absorption spectra showed that hematite $\left(\mathrm{Fe}_{2} \mathrm{O}_{3}\right)$ disappeared very quickly during initial contact with synthesis gas, while $\mathrm{Fe}_{3} \mathrm{O}_{4}$ and $\mathrm{FeC}_{\mathrm{x}}$ emerged concurrently, consistent with the observed transient exotherm. This latter process is very fast, as indicated by the observation that the concentration of $\mathrm{FeC}_{\mathrm{x}}$ reached $20 \%$ after $1 \mathrm{~min}$. Therefore, the initial exposure to synthesis gas at $543 \mathrm{~K}$ led to the removal of oxygen from the surface and bulk of $\mathrm{Fe}_{2} \mathrm{O}_{3}$ to form $\mathrm{Fe}_{3} \mathrm{O}_{4}$ and then to the introduction of carbon into the $\mathrm{Fe}$ structure to form $\mathrm{FeC}_{\mathrm{x}}$. The extent of catalyst carburization increased with the reaction time, until $\mathrm{FeC}_{\mathrm{x}}$ became the only detectable crystallographic phase after 45 min.

The sharp peak corresponding to water formation was observed initially, as described above, and then decreased with time on stream. In contrast, $\mathrm{CO}_{2}$ formation rates showed two broad formation rate peaks. The first $\mathrm{CO}_{2}$ formation feature reflects the reduction of hematite to form magnetite, while the second peak arises from reactions of Co to form iron carbides. 
The surface area of $\mathrm{Fe}-\mathrm{Zn}-\mathrm{Cu}_{3}-\mathrm{K}_{6}$ was $160 \mathrm{~m}^{2} \mathrm{~g}^{-1}$, while surface areas after contact to synthesis gas for 25, 70 and $120 \mathrm{~min}$ were 31,27 , and $17 \mathrm{~m}^{2} \mathrm{~g}^{-1}$, consistent with the sintering of Fe- $\mathrm{Zn}$ $\mathrm{Cu}_{3}-\mathrm{K}_{6}$ sample during $\mathrm{Fe}_{3} \mathrm{O}_{4}$ formation. The surface area also decreased slowly during the conversion of $\mathrm{Fe}_{3} \mathrm{O}_{4}$ to $\mathrm{FeC}_{\mathrm{x}}$. Besides, the surface area continuously decreased after $\mathrm{FeC}_{\mathrm{x}}$ concentration reached $100 \%$, suggesting that the carbide-oxide transformations led to the sintering of particles during FTS reactions at $543 \mathrm{~K}$. The activation process for $\sim 60 \mathrm{~min}$ led to the highest $\mathrm{CH}_{4}$ formation rates, suggesting that this is an optimal activation time at these conditions.

\subsubsection{Effect of activation temperature and $\mathrm{H}_{2} / \mathrm{CO}$ ratio on activation and FTS reactions.}

Figure 2.5 shows $\mathrm{FeC}_{\mathrm{x}}$ concentrations measured from in situ XAS on $\mathrm{Fe}-\mathrm{Zn}-\mathrm{Cu}_{3}-\mathrm{K}_{6}$ as a function of time at various temperatures $(508,523,543$, and $573 \mathrm{~K})$. It is clear that at 543 and $573 \mathrm{~K}, \mathrm{FeC}_{\mathrm{x}}$ contributions approached constant values of $\sim 100 \%$ after $60 \mathrm{~min}$ and $20 \mathrm{~min}$, respectively. On the other hand, the $\mathrm{FeC}_{\mathrm{x}}$ contributions at 508 and $523 \mathrm{~K}$ were $\sim 80 \%$ and $\sim 90 \%$ after 360 and $180 \mathrm{~min}$, respectively. Figure 2.5 also shows the $\mathrm{CH}_{4}$ formation rates measured at the same reaction condition as those used for the XAS experiments. The rate of $\mathrm{CH}_{4}$ formation at $508 \mathrm{~K}$ and $523 \mathrm{~K}$ increased with increasing $\mathrm{FeC}_{\mathrm{x}}$ content. At 543 and $573 \mathrm{~K}$, the $\mathrm{CH}_{4}$ formation rates increased with increasing $\mathrm{FeC}_{\mathrm{x}}$ content and then the rates decreased with time on stream. At $573 \mathrm{~K}$, deactivation evident after 5 min in contact with synthesis gas. It seems that the decrease of $\mathrm{CH}_{4}$ formation rates was caused by the formation of the inactive species, such as carbon, upon exposure of iron oxides to synthesis gas at high temperature.
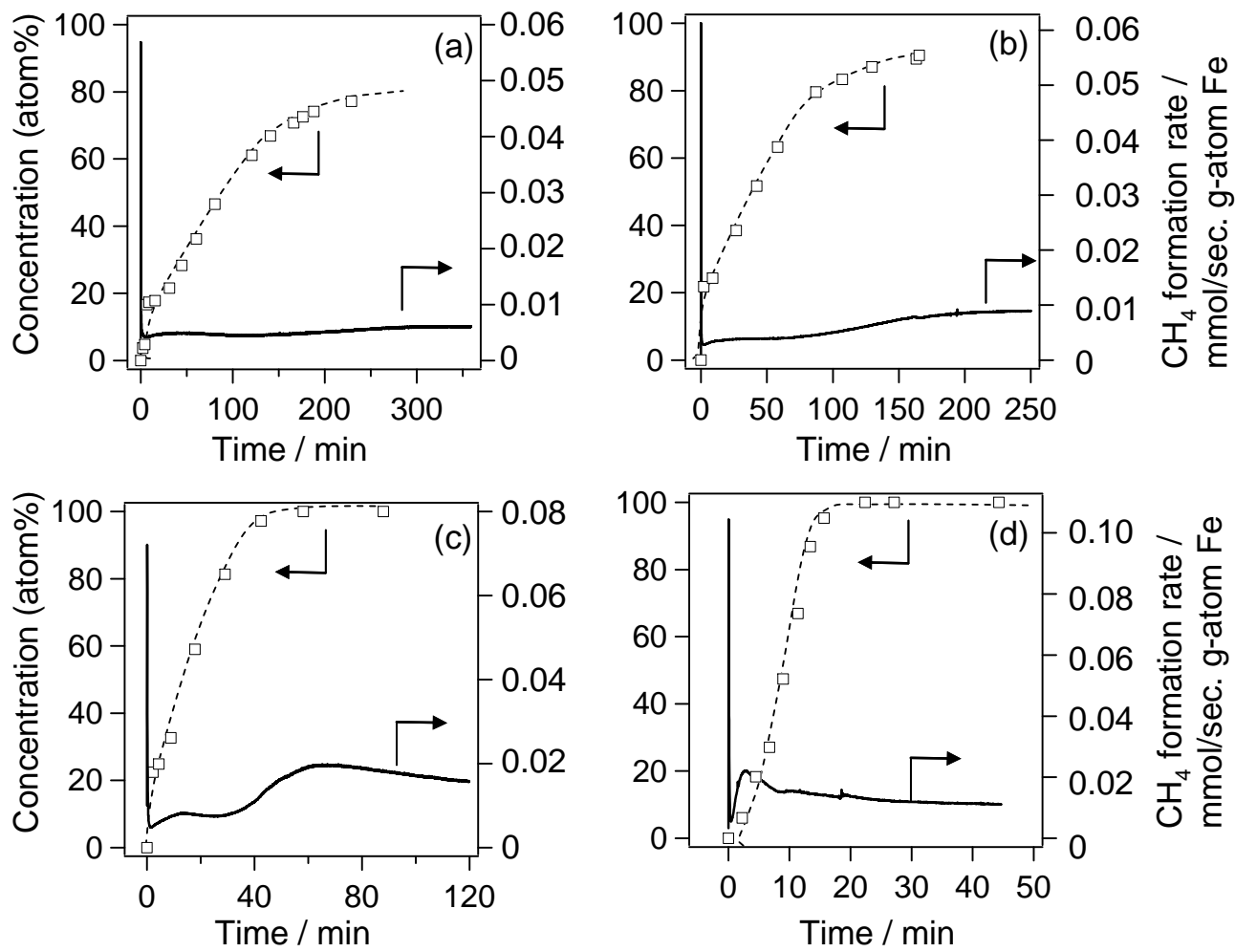

Figure 2.5. Fe carbide concentration (open mark ) obtained from XAS (1 mg sample) and rate of $\mathrm{CH}_{4}$ formation as a function of time on $\mathrm{Fe}-\mathrm{Zn}-\mathrm{Cu}_{3}-\mathrm{K}_{6}(0.2 \mathrm{~g}$ sample ) at (a) 508, (b) 523, (c) 543, and (d) $573 \mathrm{~K}$. (synthesis gas flow: $108 \mathrm{~mol} \mathrm{~h}^{-1}$ g-at Fe ${ }^{-1}$ ) 
FTS rates increased with increasing reaction temperature. To evaluate the catalytic activities by the $\mathrm{CH}_{4}$ formation rate, it is necessary to measure this rate and $\mathrm{CH}_{4}$ formation rate at the same conditions after activation process._Table 2.1 summarizes the surface area of Fe$\mathrm{Zn}-\mathrm{Cu}_{3}-\mathrm{K}_{6}$ activated at various temperatures, as well as the $\mathrm{CH}_{4}$ formation rates measured at $508 \mathrm{~K}$ after various activation processes. The activation processes at $543 \mathrm{~K}$ and $573 \mathrm{~K}$ were carried out for 70 and $5 \mathrm{~min}$, respectively, because these times lead to maximum rates on Fe$\mathrm{Zn}-\mathrm{Cu}_{3}-\mathrm{K}_{6}$ at each of these temperatures (Figure 2.5). The surface area of $\mathrm{Fe}-\mathrm{Zn}-\mathrm{Cu}_{3}-\mathrm{K}_{6}$ samples activated at $508 \mathrm{~K}$ for 360 min was the lowest among all samples and the $\mathrm{FeC}_{\mathrm{x}}$ concentration was $\sim 80 \%$. The relative surface area of the samples activated at lower temperatures $(508,523 \mathrm{~K})$ is lower than those activated at higher temperature, even though the samples included $\mathrm{Fe}_{3} \mathrm{O}_{4}$ phases. Therefore it appears that the increase of activation temperature results in an increase in surface area. The activation at high temperature appears to lead to preferential nucleation at multiple locations and to smaller structures of $\mathrm{Fe}_{2} \mathrm{O}_{3}$ and $\mathrm{Fe}$ carbide.

Fe- $\mathrm{Zn}-\mathrm{Cu}_{3}-\mathrm{K}_{6}$ samples activated at $508 \mathrm{~K}$ for 360 min showed the highest $\mathrm{CH}_{4}$ formation rate among all catalysts. There are two possible basis for this observation. One is rapid catalyst deactivation at higher temperature. The contact of $\mathrm{Fe}-\mathrm{Zn}-\mathrm{Cu}_{3}-\mathrm{K}_{6}$ with synthesis gas at $573 \mathrm{~K}$ causes deactivation even after 5 min in spite of the low $\mathrm{FeC}_{\mathrm{x}}$ concentration $(20 \%)$ prevalent after this period of time. The other is that active sites formed via promoters depend on the location and effectiveness of these promoters. $\mathrm{Cu}$ and $\mathrm{K}$ species on $\mathrm{Fe}_{2} \mathrm{O}_{3}$ surface promote the reduction and carburization of $\mathrm{Fe}_{2} \mathrm{O}_{3}$. The reduction and carburization of $\mathrm{Fe}-\mathrm{Zn}-\mathrm{Cu}_{3}-\mathrm{K}_{6}$ at lower temperature occur by using $\mathrm{H}_{2}$ and $\mathrm{CO}$ activated via promoters. The reduction and carburization by $\mathrm{H}_{2}$ and $\mathrm{CO}$ activated via $\mathrm{Fe}_{2} \mathrm{O}_{3}$ itself, however, can also occur at higher temperature Therefore, it appears that the $\mathrm{Fe}-\mathrm{Zn}-\mathrm{Cu}_{3}-\mathrm{K}_{6}$ activated at lower temperature $(523 \mathrm{~K})$ appears to involve the beneficial effects of promoters near the active sites with consequent beneficial effects on the density and reactivity of active sites for the FT synthesis.

Table 2.1. Characterization results and $\mathrm{CH}_{4}$ formation rate over $\mathrm{Fe}-\mathrm{Zn}-\mathrm{Cu}_{3}-\mathrm{K}_{6}$ activated at various temperature and time.

\begin{tabular}{ccccccc}
\hline $\begin{array}{c}\text { Temperature }(\mathrm{K}) \\
\text { Activation time (min) }\end{array}$ & 508 & 523 & 543 & 543 & 573 & 573 \\
\hline Surface area $\left(\mathrm{m}^{2} \mathrm{~g}^{-1}\right)^{\mathrm{a}}$ & 12.1 & 14.6 & 26.9 & 16.8 & 42.5 & 31.3 \\
$\mathrm{FeC}_{\mathrm{x}}$ concentration (\%) & 82 & 91 & 100 & 100 & 21 & 100 \\
$\begin{array}{c}\mathrm{CH} \text { formation rate } \\
\left(\mathrm{mmol} \mathrm{s}^{-1} \text { g-at } \mathrm{Fe}^{-1}\right)^{\mathrm{c}}\end{array}$ & 0.0060 & 0.0054 & 0.0052 & 0.0047 & 0.0039 & 0.0031 \\
\hline
\end{tabular}

a Surface area measured after activation.

${ }^{\mathrm{b}} \mathrm{FeC}_{\mathrm{x}}$ concentration measured after exposure to synthesis gas ( $1 \mathrm{mg} \mathrm{Fe}-\mathrm{Zn}-\mathrm{Cu}_{3}-\mathrm{K}_{6}, \mathrm{H}_{2} / \mathrm{CO}=1$, synthesis gas flow rate $=108 \mathrm{~mol} \mathrm{~h}^{-1} \mathrm{~g}$-at Fe $\mathrm{Fe}^{-1}$ ).

${ }^{\mathrm{c}} \mathrm{CH}_{4}$ formation rates measured at $508 \mathrm{~K}$ after activation $\left(0.2 \mathrm{~g} \mathrm{Fe}-\mathrm{Zn}-\mathrm{Cu}_{3}-\mathrm{K}_{6}, \mathrm{H}_{2} / \mathrm{CO}=1\right.$, synthesis gas flow rate $=108 \mathrm{~mol} \mathrm{~h}^{-1} \mathrm{~g}$-at $\mathrm{Fe}^{-1}$ ). 


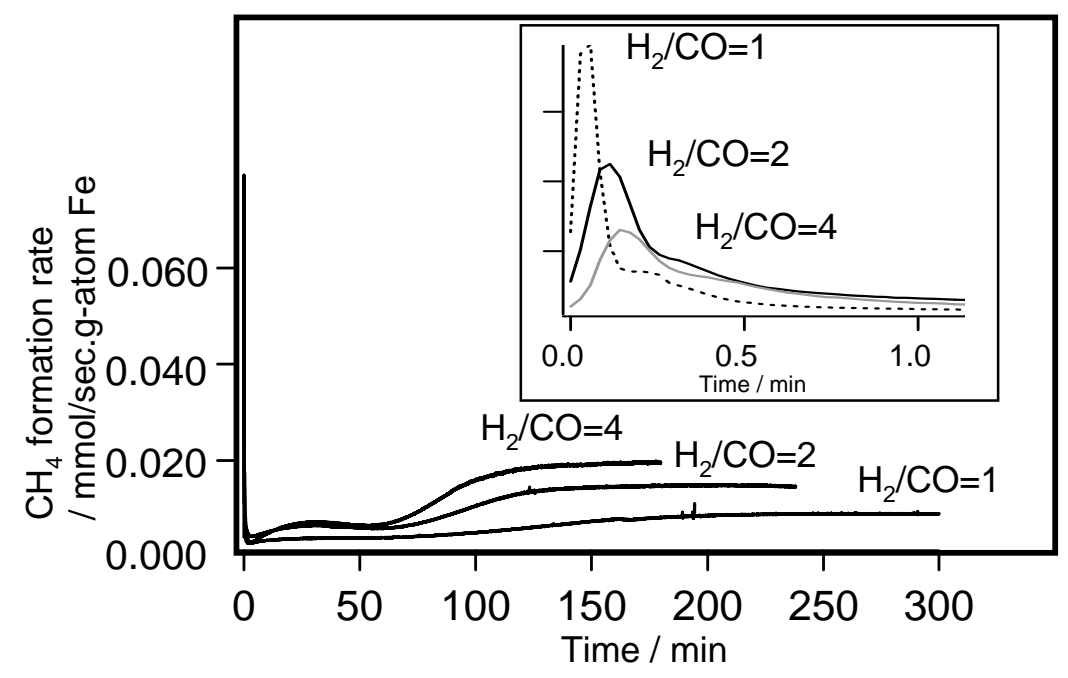

Figure 2.6. $\mathrm{CH}_{4}$ formation rate on $\mathrm{Fe}-\mathrm{Zn}-\mathrm{Cu}_{3}-\mathrm{K}_{6}$ as a function of time under synthesis gas stream with various $\mathrm{H}_{2} / \mathrm{CO}$ ratios at $523 \mathrm{~K}$. (syngas flow: $108 \mathrm{~mol} \mathrm{~h}^{-1} \mathrm{~g}$-at Fe $^{-1}$ ).

$\mathrm{CH}_{4}$ formation rates of $\mathrm{Fe}-\mathrm{Zn}-\mathrm{Cu}_{3}-\mathrm{K}_{6}$ were measured to determine the effects of activation with gas mixtures with varying $\mathrm{H}_{2} / \mathrm{CO}$ ratios. Figure 2.6 shows $\mathrm{CH}_{4}$ formation rates on $\mathrm{Fe}-\mathrm{Zn}$ $\mathrm{Cu}_{3}-\mathrm{K}_{6}$ with such mixtures at $508 \mathrm{~K}$. The increase of reactor temperature became small in the initial stage $(\sim 0.5 \mathrm{~min})$ with increasing $\mathrm{H}_{2} / \mathrm{CO}$ ratio and the sharp peak in that stage consequently became broad, suggesting that higher $\mathrm{H}_{2} / \mathrm{CO}$ ratio led to slower rates of $\mathrm{FeC}_{\mathrm{x}}$ formation at near-surface regions. Since $\mathrm{CH}_{4}$ formation rates cannot be used to judge exposed site densities, because of the effects of $\mathrm{H}_{2} / \mathrm{CO}$ ratios on intrinsic reaction rates, we have examined the effects of activation procedures by measuring surface areas and FTS rates at standard reaction conditions.

Figure 2.7 shows the surface area and $\mathrm{CH}_{4}$ formation rate of $\mathrm{Fe}-\mathrm{Zn}-\mathrm{Cu}_{3}-\mathrm{K}_{6}$ at identical conditions $\left(\mathrm{H}_{2} / \mathrm{CO}=1,508 \mathrm{~K}, 0.1 \mathrm{MPa}\right)$ after catalyst activation at $523 \mathrm{~K}$ under synthesis gas stream with different $\mathrm{H}_{2} / \mathrm{CO}$ ratios. The $\mathrm{CH}_{4}$ formation rate on $\mathrm{Fe}-\mathrm{Zn}-\mathrm{Cu}_{3}-\mathrm{K}_{6}$ activated with $\mathrm{H}_{2} / \mathrm{CO}=1$ was lower than on $\mathrm{Fe}-\mathrm{Zn}-\mathrm{Cu}_{3}-\mathrm{K}_{6}$ activated with $\mathrm{H}_{2} / \mathrm{CO}=2$. Fe- $\mathrm{Zn}$ oxide without promoters can be reduced to $\mathrm{Fe}_{3} \mathrm{O}_{4}$ by $\mathrm{CO}$ at $523 \mathrm{~K}$, while it cannot be reduced by $\mathrm{H}_{2}$. This implies that the CO-rich synthesis gas led to reduction by $\mathrm{CO}$ activated on $\mathrm{Fe}_{2} \mathrm{O}_{3}$ itself, but required reduction by $\mathrm{H}_{2}$ activated on promoters. This reduction by $\mathrm{CO}$ activated via $\mathrm{Fe}_{2} \mathrm{O}_{3}$ causes a weakening of promoter effects on the rate of formation and the concentration of active species. On the other hand, $\mathrm{Fe}-\mathrm{Zn}-\mathrm{Cu}_{3}-\mathrm{K}_{6}$ activated at high $\mathrm{H}_{2} / \mathrm{CO}$ ratioss $\left(\mathrm{H}_{2} / \mathrm{CO}=4\right)$ gave the lowest $\mathrm{CH}_{4}$ formation rates. It appears that this case also brings about the lack of promoter because of the relatively rapid active site formation irrespective of the presence or absence of promoter components. $\mathrm{Fe}-\mathrm{Zn}-\mathrm{Cu}_{3}-\mathrm{K}_{6}$ samples activated with stoichiometric synthesis gas $\left(\mathrm{H}_{2} / \mathrm{CO}=2\right)$ gave the highest $\mathrm{CH}_{4}$ formation rate among all catalysts. 


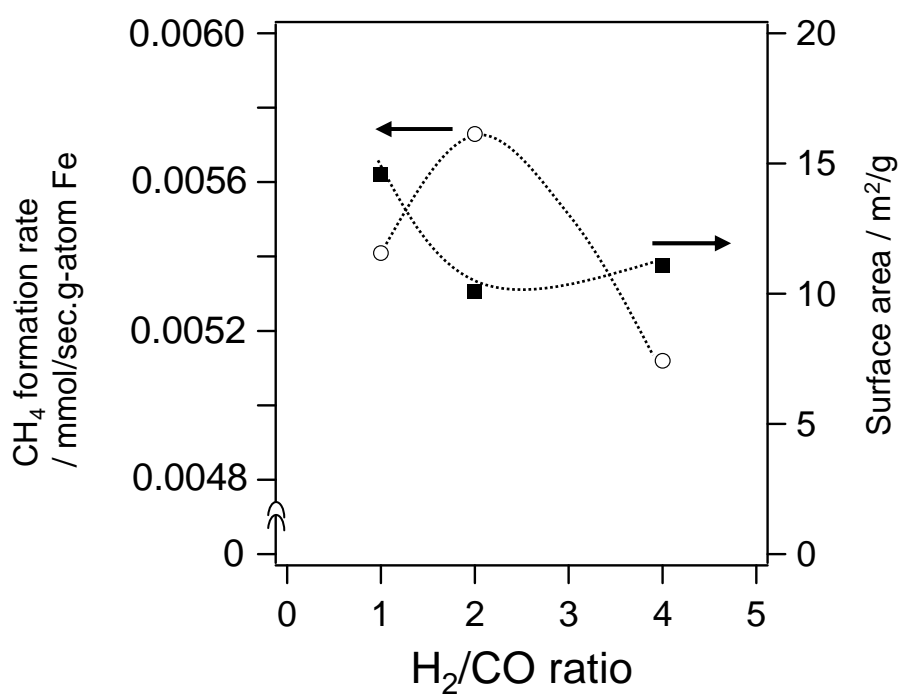

Figure 2.7. Surface area and $\mathrm{CH}_{4}$ formation rate at $508 \mathrm{~K}$ and $0.1 \mathrm{MPa}$ under synthesis gas flow $\left(\mathrm{H}_{2} / \mathrm{CO}=1\right)$ after catalyst activation at $523 \mathrm{~K}$ under synthesis gas flow with various $\mathrm{H}_{2} / \mathrm{CO}$ ratios. (Fe-Zn-Cu $-\mathrm{K}_{6}$; syngas flow rate: $108 \mathrm{~mol} \mathrm{~h}^{-1} \mathrm{~g}$-at $\mathrm{Fe}^{-1}$ ).

FTS rates and selectivities were measured on Fe-Zn- $\mathrm{Cu}_{3}-\mathrm{K}_{6}$ samples with hydrogen-poor synthesis gas $\left(\mathrm{H}_{2} / \mathrm{CO}=1\right)$ reactant after catalyst activation with stoichiometric synthesis gas $\left(\mathrm{H}_{2} / \mathrm{CO}=2\right)$ reactant at $508 \mathrm{~K}$ and three flow rates $(21.6,54.0,108 \mathrm{~mol} / \mathrm{h}$.g-atom $\mathrm{Fe})$. The highest flow rate $\left(108 \mathrm{~mol} \mathrm{~h}^{-1} \mathrm{~g}\right.$-at $\left.\mathrm{Fe}^{-1}\right)$ was the same as that used on the transient FTS experiments reported above. Table 2.2 summarizes the steady-state performance of $\mathrm{Fe}-\mathrm{Zn}_{-}-\mathrm{Cu}_{3}-$ $\mathrm{K}_{6}$ activated at $508 \mathrm{~K}$ at these synthesis gas flow rates. Table 2.2 also shows the steady-state performance of $\mathrm{Fe}-\mathrm{Zn}-\mathrm{Cu}_{3}-\mathrm{K}_{6}$ activated using conventional methods [1]. Decreasing reactant flow rates during activation process led to higher hydrocarbon formation rates. Hydrocarbon formation rates on $\mathrm{Fe}-\mathrm{Zn}-\mathrm{Cu}_{3}-\mathrm{K}_{6}$ activated with stoichiometric synthesis reactants $\left(\mathrm{H}_{2} / \mathrm{CO}=2\right.$, flow rate $21.6 \mathrm{~mol} \mathrm{~h}^{-1} \mathrm{~g}$-at $\mathrm{Fe}^{-1}$ ) at $508 \mathrm{~K}$ was higher compared than on catalysts activated with other compositions. Fe-based catalysts are typically activated above $573 \mathrm{~K}$. Our study suggests that lower reactor temperature can be sufficient to activate catalysts and lead to the improved FTS catalyst performance.

Table 2.2. Steady-state FTS performance of $\mathrm{Fe}-\mathrm{Zn}-\mathrm{Cu}_{3}-\mathrm{K}_{6}$ activated at several conditions. $\left(\mathrm{H}_{2} / \mathrm{CO}=1,508 \mathrm{~K}, 2.14 \mathrm{MPa}, \mathrm{CO}\right.$ conversion $\left.29-32 \%\right)$.

\begin{tabular}{ccccc}
\hline $\begin{array}{c}\text { Activation Temperature }(\mathrm{K}) \\
\begin{array}{c}\text { Flow rate } \\
\left(\mathrm{mol} \mathrm{h}^{-1} \mathrm{~g} \text {-at Fe }\right)^{-1}\end{array}\end{array}$ & 543 & 508 & 508 & 508 \\
\hline $\begin{array}{c}\text { Steady-state performance } \\
\mathrm{CO}_{2} \text { selectivity (\%) }\end{array}$ & 21.6 & 21.6 & 54.0 & 108 \\
$\mathrm{CH}_{4}$ selectivity (\%) & 4.9 & 35.3 & 34.6 & 31.4 \\
$\mathrm{C}_{5+}$ selectivity (\%) & & & & \\
\end{tabular}


${ }^{\text {a }}$ Synthesis gas $\left(\mathrm{H}_{2} / \mathrm{CO}=2\right)$.

${ }^{\mathrm{b}} \mathrm{CH}_{4}$ and $\mathrm{C}_{5+}$ selectivities are reported on a $\mathrm{CO}_{2}$-free basis.

\section{Mechanism and kinetics of the Fischer-Tropsch synthesis on Fe-based catalysts.}

The detailed kinetics and reaction mechanism of the Fischer-Tropsch synthesis (FTS) were also addressed as part of this project. Kinetic measurements were performed on a $\mathrm{Fe}-\mathrm{Zn}-\mathrm{Cu}_{3}-\mathrm{K}_{6}$ catalyst, which was found to be the most active material among those developed as part of this study. The ultimate objective of these experiments is to propose a reaction mechanism that describes and predicts the formation rates of various hydrocarbons formed during reactions of $\mathrm{CO}$ and $\mathrm{H}_{2}$ on Fe-based catalysts and which can be used to embed into hydrodynamic models of complex practical reactors.

\subsection{Influence of reactants partial pressure on hydrocarbon formation rate.}

The rates of $\mathrm{CO}$ conversion to hydrocarbons $(\mathrm{HC})$ as a function of the $\mathrm{CO}$ conversion at different inlet $\mathrm{CO}$ and $\mathrm{H}_{2}$ partial pressures are shown in Figures_3.1 and 3.2 respectively. These data were obtained by changing the $\mathrm{CO}$ space velocity while keeping $\mathrm{t}$ the reaction temperature $(508 \mathrm{~K})$ and all other pressures constant. The rates of $\mathrm{CO}$ conversion to hydrocarbon decreased with increasing $\mathrm{CO}$ conversion in all experiments, probably as a result of the depletion of reactants. The decrease of the $\mathrm{CO}$ conversion rate to hydrocarbons with increasing $\mathrm{CO}$ conversion may also reflect inhibition effects caused by competitive adsorption of water formed during FTS reactions [17]. It has been shown in the literature that the rate of FTS is not inhibited by the addition of water with the syngas feed for $\mathrm{H}_{2} \mathrm{O} / \mathrm{CO}$ ratios less than 0.3 [18]. Under our reactions conditions, the water-to-carbon monoxide ratio inside the catalytic bed was below 0.3 at all reaction conditions.

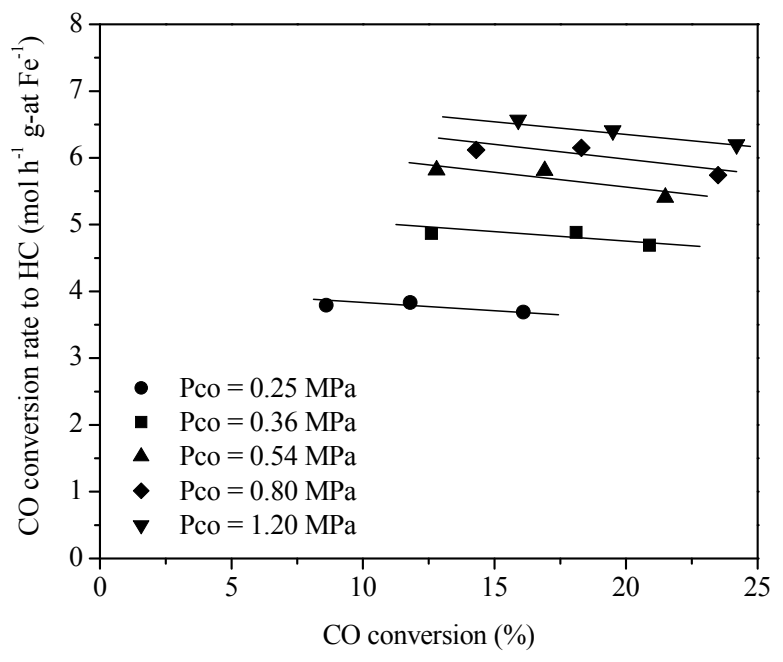

Figure 3.1. $\mathrm{CO}$ conversion rate to hydrocarbons as a function of $\mathrm{CO}$ conversion at different inlet $\mathrm{CO}$ partial pressures $\left(\mathrm{H}_{2}=1.20 \mathrm{MPa}\right)$. 


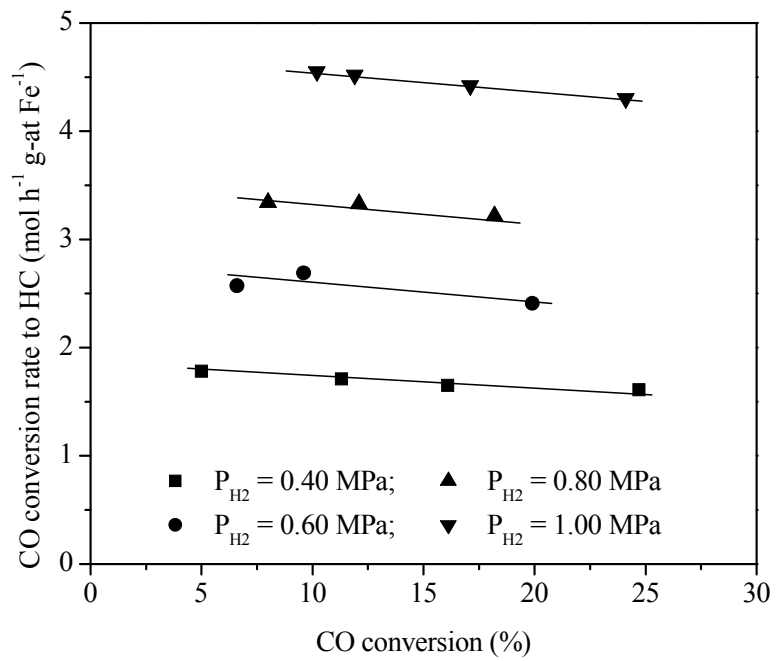

Figure 3.2. $\mathrm{CO}$ conversion rate to hydrocarbons as a function of $\mathrm{CO}$ conversion at different inlet $\mathrm{H}_{2}$ partial pressures $(\mathrm{CO}=0.40 \mathrm{MPa})$.

Figure 3.3 shows the rate of $\mathrm{CO}$ conversion to hydrocarbons extrapolated at zero $\mathrm{CO}$ conversion level at different $\mathrm{CO}$ and $\mathrm{H}_{2}$ pressures. The reaction rate is approximately first order in $\mathrm{CO}$ at low $\mathrm{CO}$ inlet partial pressures, but becomes almost zero order at higher $\mathrm{CO}$ pressures. The reaction orders with respect to $\mathrm{CO}$ reported in the literature are between -0.5 and $+0.5[4,19,20]$. In contrast, $\mathrm{CO}$ conversion rates to hydrocarbon increased linearly with increasing $\mathrm{H}_{2}$ pressure (0.4-1.0 MPa.

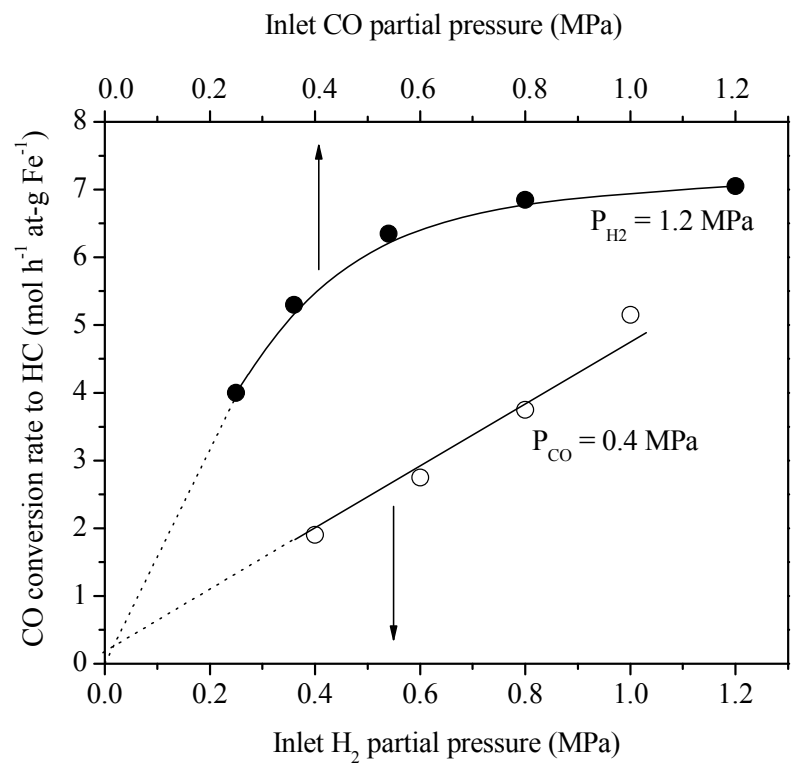

Figure 3.3. Effect of $\mathrm{CO}$ and $\mathrm{H}_{2}$ partial pressures on the $\mathrm{CO}$ conversion rate to hydrocarbon extrapolated a zero $\mathrm{CO}$ conversion. 


\section{2. $\mathrm{CO}_{2} / \mathrm{H}_{2} \mathrm{O}$ formation and oxygen removal selectivity.}

Water-gas shift (WGS) is a reversible reaction that approaches equilibrium with increasing residence time and temperature during FTS reactions. This approach to equilibrium and its kinetic consequences can be rigorously described by a parameter $\eta$ :

$$
\eta=\frac{1}{\mathrm{~K}_{\mathrm{wGS}}} \cdot \frac{\mathrm{P}_{\mathrm{CO}_{2}} \mathrm{P}_{\mathrm{H}_{2}}}{\mathrm{P}_{\mathrm{CO}} \mathrm{P}_{\mathrm{H}_{2} \mathrm{O}}}
$$

where $\mathrm{P}_{i}$ is the partial pressure of species $i$ and $\mathrm{K}_{\mathrm{WGS}}$ is the equilibrium constant for the WGS at the prevalent FTS reaction temperature. The values of $\eta$ increase from 0 to 1 as WGS reaction approach equilibrium. It has been previously shown that [7]:

$$
r=r_{f}-r_{r}=r_{f}(1-\eta)
$$

where $r, r_{f}$ and $r_{r}$ are respectively the net, forward and reverse rate of $\mathrm{CO}_{2}$ formation. This expression was used here to calculate the rate of forward $\mathrm{CO}_{2}$ formation at various $\mathrm{H}_{2}$ and $\mathrm{CO}$ pressures.

Figure 3.4 shows the forward rate of $\mathrm{CO}_{2}$ formation as a function of the $\mathrm{CO}$ conversion at different inlet $\mathrm{CO}$ partial pressures. These data were obtained by changing the $\mathrm{CO}$ space velocity at constant temperature $(508 \mathrm{~K})$ and $\mathrm{H}_{2}$ partial pressure $(1.20 \mathrm{MPa})$. The forward rate of $\mathrm{CO}_{2}$ formation increases with increasing $\mathrm{CO}$ conversion and $\mathrm{CO}$ pressure. The effect of $\mathrm{CO}$ conversion reflects the formation of $\mathrm{CO}_{2}$ via secondary WGS reactions. The slope of $\mathrm{CO}_{2}$ formation rate with residence time reflects the rate of secondary WGS reactions and increase slightly with increasing inlet $\mathrm{CO}$ pressure. The forward rate of $\mathrm{CO}_{2}$ formation extrapolated to zero $\mathrm{CO}$ conversion levels are non-zero at all conditions, consistent with the primary formation of $\mathrm{CO}_{2}$ via reactions of chemisorbed carbon monoxide $\left(\mathrm{CO}^{*}\right)$ and oxygen $\left(\mathrm{O}^{*}\right)$ $\left(\mathrm{CO}^{*}+\mathrm{O}^{*} \rightarrow \mathrm{CO}_{2}\right)$. It is evident from these data that the main effect of increasing inlet $\mathrm{CO}$ partial pressures on $\mathrm{CO}_{2}$ formation pathways is to enhance the rate of primary $\mathrm{CO}_{2}$ formation. Figure 3.5 depicts the rate of primary $\mathrm{CO}_{2}$ formation as a function of the inlet $\mathrm{CO}$ partial pressure. The rate of primary $\mathrm{CO}_{2}$ formation increases linearly at low $\mathrm{CO}$ partial pressure. On the contrary, this rate is almost zero-order in $\mathrm{CO}$ at higher $\mathrm{CO}$ partial pressures.

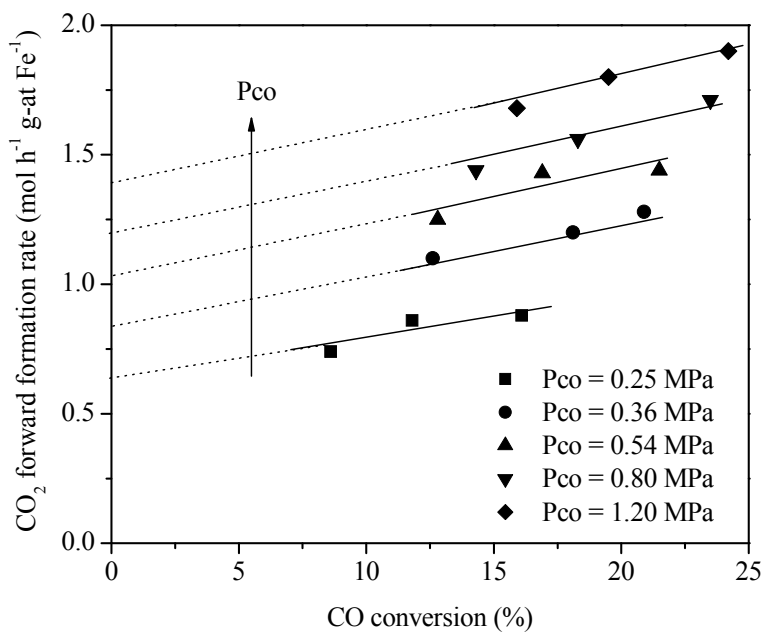

Figure 3.4. Rate of forward $\mathrm{CO}_{2}$ formation as a function of $\mathrm{CO}$ conversion at different inlet $\mathrm{CO}$ pressures $\left(\mathrm{H}_{2}=1.20 \mathrm{MPa}\right)$. 


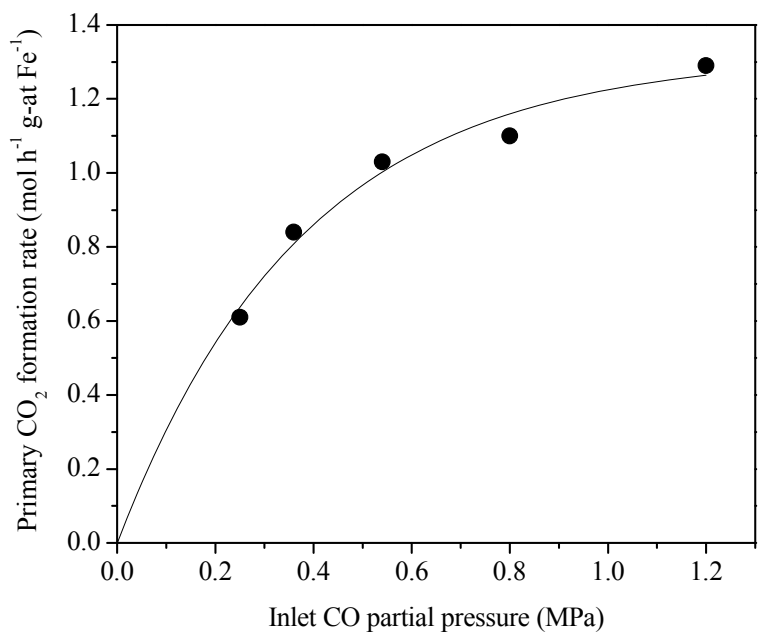

Figure 3.5. Rate of primary $\mathrm{CO}_{2}$ formation as a function of inlet $\mathrm{CO}$ partial pressure $\left(\mathrm{H}_{2}=1.20\right.$ $\mathrm{MPa})$.

Figure 3.6 shows the forward rate of $\mathrm{CO}_{2}$ formation as a function of $\mathrm{CO}$ conversion for different inlet $\mathrm{H}_{2}$ partial pressures. As described above, the forward rate of $\mathrm{CO}_{2}$ formation increased with increasing $\mathrm{CO}$ conversion. However, the intercept with the y-axis at zero $\mathrm{CO}$ conversion level and the slopes of the rate of forward $\mathrm{CO}_{2}$ formation are independent of inlet $\mathrm{H}_{2}$ pressures, suggesting that $\mathrm{H}_{2}$ pressures do not affect the rate at which oxygen from $\mathrm{CO}$ is removed as $\mathrm{CO}_{2}$ via primary reactions or secondary WGS. Figure 3.7 shows clearly that the rate of primary $\mathrm{CO}_{2}$ formation is independent on the inlet $\mathrm{H}_{2}$ partial pressure.

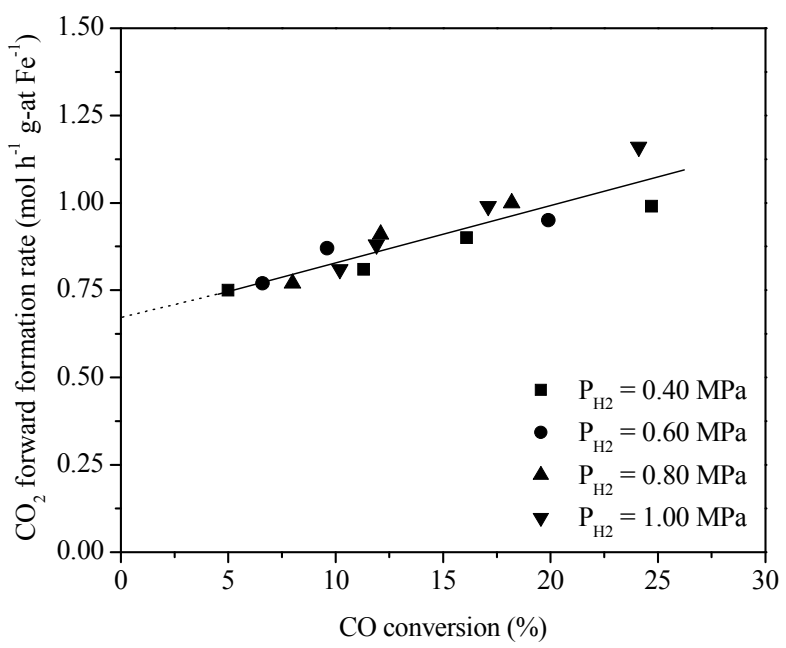

Figure 3.6. Forward rate of $\mathrm{CO}_{2}$ formation as a function of $\mathrm{CO}$ conversion at different inlet $\mathrm{H}_{2}$ partial pressures $(\mathrm{CO}=0.40 \mathrm{MPa})$. 


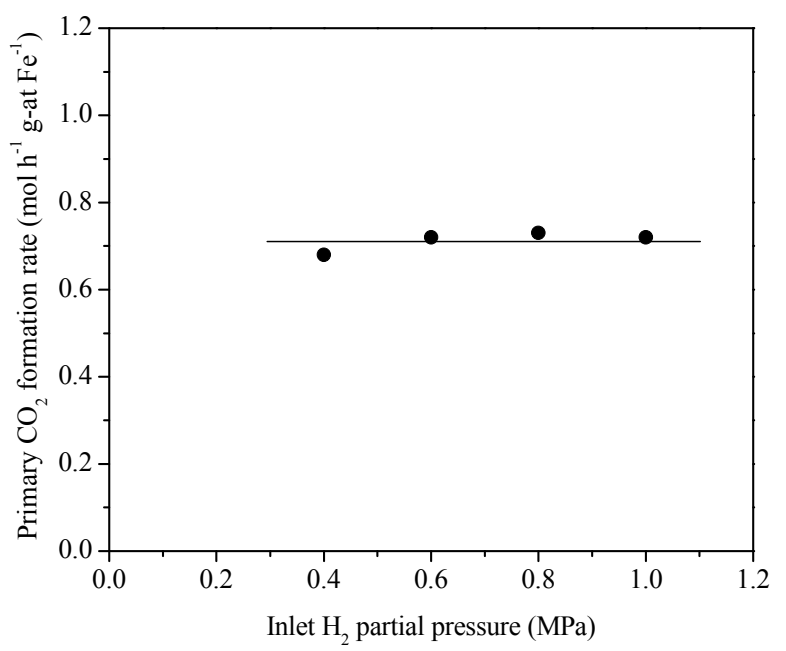

Figure 3.7. Rate of primary $\mathrm{CO}_{2}$ formation as a function of the inlet $\mathrm{H}_{2}$ partial pressure $(\mathrm{CO}=0.40 \mathrm{MPa})$.

The dependence of the rate of forward $\mathrm{CO}_{2}$ formation on the mean $\mathrm{CO}_{2}$ pressure in the reactor was also examined in our experiments (Figure 3.8). The forward rate of $\mathrm{CO}_{2}$ formation was unaffected by the prevalent $\mathrm{CO}_{2}$ pressure within the reactor. The forward and net rates of carbon dioxide formation are almost identical because WGS reaction is far from the equilibrium $\left(\eta_{\max }=0.105\right)$ under our reaction conditions. This means that added $\mathrm{CO}_{2}$ was not significantly converted to $\mathrm{CO}$ via the reverse water-gas shift reaction $\left(\mathrm{CO}_{2}+\mathrm{H}_{2} \leftrightarrows \mathrm{CO}+\mathrm{H}_{2} \mathrm{O}\right)$ during these experiments.

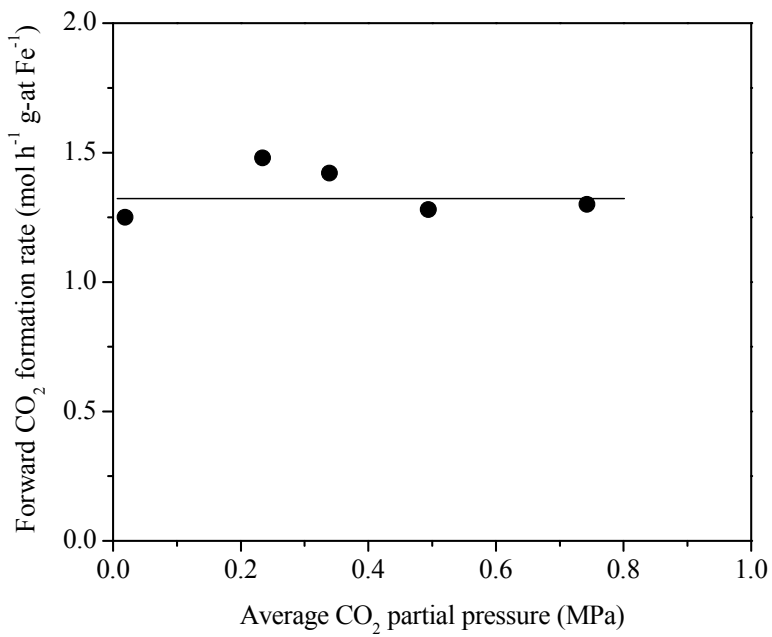

Figure 3.8. Forward rate of $\mathrm{CO}_{2}$ formation as a function of the average $\mathrm{CO}_{2}$ partial pressure $\left(\mathrm{P}_{\mathrm{CO}}=\mathrm{H}_{2}=0.75 \mathrm{MPa}\right)$.

\subsection{Fischer-Tropsch synthesis mechanism on Fe-based catalysts.}

The analysis of the observed kinetic dependence of the rate of hydrocarbons and primary $\mathrm{CO}_{2}$ formation on the reactants partial pressures led us to propose the following set of elementary steps for FTS: 


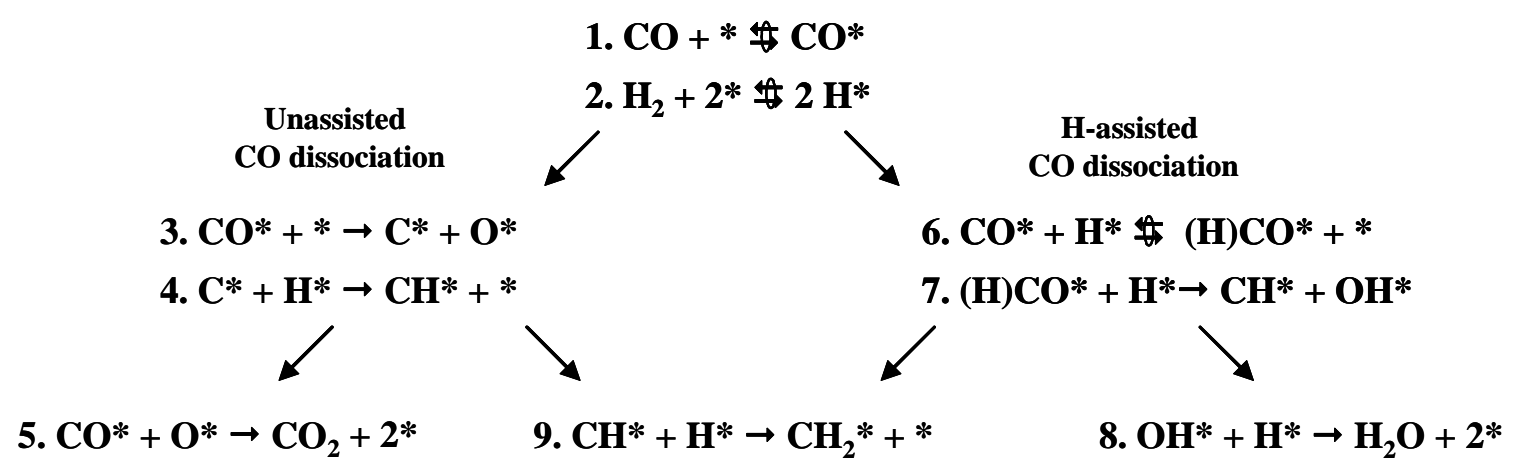

Scheme 3.1. Proposed elementary steps for Fischer-Tropsch synthesis on Fe catalysts.

The first step describes the molecular non-activated adsorption of carbon monoxide [21]. The dissociative adsorption of hydrogen (step 2) requires two vacant active sites, typically on surfaces nearly saturated with chemisorbed CO. Both steps are typically assume to be equilibrated because of their low activation barriers and modest exothermic enthalpies of adsorption. The dissociation of adsorbed $\mathrm{CO}$ species $\left(\mathrm{CO}^{*}\right)$ can occur via two independent pathways - unassisted dissociation and $\mathrm{H}$-assisted dissociation. In the unassisted route, $\mathrm{CO}^{*}$ species cleave their $\mathrm{C}-\mathrm{O}$ bonds directly to form surface carbon $\left(\mathrm{C}^{*}\right)$ and oxygen $\left(\mathrm{O}^{*}\right)$ species using a vicinal empty site (step 3). The $\mathrm{C}^{*}$ species are then hydrogenated to form $\mathrm{CH}^{*}$ species (step 4) and ultimately monomers for chain growth. Surface $\mathrm{O}^{*}$ species are removed exclusively by reaction with $\mathrm{CO}^{*}$ to produce primary carbon dioxide (step 5). It would be reasonable to consider that $\mathrm{O}^{*}$ species can also be stepwise hydrogenated to form water. Parallel density functional theory calculations and the comparison with data discussed below indicate that the first hydrogenation step $\left(\mathrm{O}^{*}+\mathrm{H}^{*} \rightarrow \mathrm{OH}^{*}\right)$ requires, however, a very high activation energy, and consequently, surface $\mathrm{O}^{*}$ species are preferential removed as $\mathrm{CO}_{2}$. In assisted routes, $\mathrm{CO}^{*}$ dissociation occurs also with the participation of $\mathrm{H}^{*}$ species $(\mathrm{H}$-assisted route). Thus, $\mathrm{CO}^{*}$ species first react with $\mathrm{H}^{*}$ to form hydrogenated $\mathrm{CO}^{*}$ species (step 6). Next, these species are dissociated with the participation of $\mathrm{H}^{*}$ to form surface $\mathrm{CH}^{*}$ and $\mathrm{OH}^{*}$ groups (step 7). These $\mathrm{OH}^{*}$ groups are the hydrogenated to form water (step 8) [22,23], while hydrogenation of the $\mathrm{CH}^{*}$ species formed in steps 4 and 7 leads to the surface FTS monomers, $\mathrm{CH}_{2} *$ (step 9).

\subsection{Kinetic analysis of the Fischer-Tropsch Synthesis with Fe-based catalysts.}

The following rate expression can be derived from the reaction mechanism presented in Scheme 3.1:

$$
\mathrm{r}_{\mathrm{HC}}=\frac{\mathrm{K}_{1} \mathrm{~K}_{2} \mathrm{~K}_{6} \mathrm{k}_{7} \mathrm{P}_{\mathrm{H}_{2}} \mathrm{P}_{\mathrm{CO}}}{\left(1+\mathrm{K}_{1} \mathrm{P}_{\mathrm{CO}}\right)^{2}}+\frac{\mathrm{K}_{1} \mathrm{k}_{3} \mathrm{P}_{\mathrm{CO}}}{\left(1+\mathrm{K}_{1} \mathrm{P}_{\mathrm{CO}}\right)^{2}}
$$

This rate equation was derived by assuming that: (i) adsorption of hydrogen and carbon monoxide are quasi-equilibrated with their gas phase concentrations (9); (ii) CO is adsorbed much more strongly than $\mathrm{H}_{2}$ and chemisorbed $\mathrm{CO}$ is therefore the most abundant surface species along with free sites [6]; (iii) the concentrations of all intermediates on the catalyst surface are at steady-state; and (iv) catalytic sites for hydrocarbons formation are uniform and homogeneously distributed (Langmuirian surface assumption) [24]. 
This rate expression reflects the formation of hydrocarbons from $\mathrm{CO}$ activated via the two proposed routes. The first term represent the formation of hydrocarbon via the $\mathrm{H}$-assisted pathway, while the second term corresponds to the unassisted route. According to the FTS mechanism here proposed, the first term in Equation 3.3 also reflects the rate of water formation, because oxygen rejection occurs exclusively as water in assisted pathways, while the second term denotes the rate of primary $\mathrm{CO}_{2}$ formation, because of its exclusive role as the oxygen rejection route in assisted pathways. Therefore, the relative rate of oxygen removal as $\mathrm{H}_{2} \mathrm{O}$ or $\mathrm{CO}_{2}$ is given by:

$$
\frac{\mathrm{r}_{\mathrm{H}_{2} \mathrm{O}}}{\mathrm{r}_{\mathrm{CO}_{2}}}=\frac{\mathrm{K}_{2} \mathrm{~K}_{6} \mathrm{k}_{7}}{\mathrm{k}_{3}} \cdot \mathrm{P}_{\mathrm{H}_{2}}
$$

According to this expression, the ratio $\mathrm{r}_{\mathrm{H}_{2} \mathrm{O}} / \mathrm{r}_{\mathrm{CO}_{2}}$ should be first order with respect the $\mathrm{H}_{2}$ pressure and independent on the CO pressure. This is in contrast with the prediction obtained from the classical FTS mechanism, which predicts a markedly different behavior. Figure 3.9 shows that measured data agree well with the predictions of our proposed mechanism and with the form of Equation 3.4. The relative importance of assisted and unassisted $\mathrm{CO}$ dissociation pathways on the rate of hydrocarbon formation is therefore given by the $\mathrm{r}_{\mathrm{H}_{2} \mathrm{O}} / \mathrm{r}_{\mathrm{CO}_{2}}$ ratio, because the rate of water formation $\left(\mathrm{r}_{\mathrm{H}_{2} \mathrm{O}}\right)$ reflects the extent of the $\mathrm{H}$-assisted $\mathrm{CO}$ dissociation pathway, while the rate of $\mathrm{CO}_{2}$ formation $\left(\mathrm{r}_{\mathrm{CO}_{2}}\right)$ corresponds to the rate of unassisted pathways. Figure 3.9 shows that both $\mathrm{CO}$ activation pathways occur concurrently on $\mathrm{Fe}$ surfaces, although the hydrogen-assisted $\mathrm{CO}$ dissociation steps prevail prevails over unassisted paths at hydrogen partial pressures typical for commercial FTS practice (1-3 MPa).

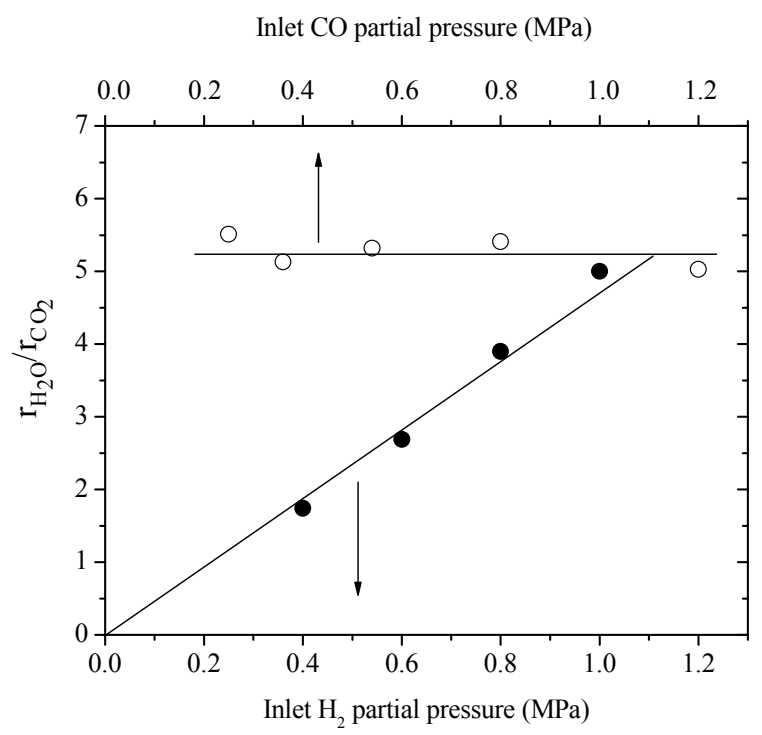

Figure 3.9. Oxygen removal selectivity $\left(\mathrm{r}_{\mathrm{H}_{2} \mathrm{O}} / \mathrm{r}_{\mathrm{CO}_{2}}\right)$ as a function of $\mathrm{CO}$ and $\mathrm{H}_{2}$ partial pressures.

Table 3.1 shows the kinetic analysis of FTS and oxygen rejection pathways based on our data and proposed elementary steps. A nonlinear regression method was used in order to fit the experimental data to the different rate expressions. The model parameters were calculated from 
the experimental data by using Levenberg-Marquardt steepest descent methods and all the reaction rate data available. It is observed that the kinetic parameters $\left(\mathrm{K}_{1} \mathrm{~K}_{2} \mathrm{~K}_{6} \mathrm{k}_{7}\right.$ and $\left.\mathrm{K}_{1} \mathrm{k}_{3}\right)$ obtained from different and independent measurements are in agreement, consistent with the accuracy and validity of the FTS mechanism here proposed. The equilibrium constant for the $\mathrm{CO}$ adsorption process $\left(\mathrm{K}_{1}\right)$ can be calculated from the kinetic parameters in Table 3.1. We have found that $\mathrm{K}_{1}=0.77 \pm 0.14 \mathrm{MPa}^{-1}$, which resembles the value reported by van der Laan and Beenackers [25] on $\mathrm{Fe}-\mathrm{Cu}-\mathrm{K}-\mathrm{SiO}_{2}$ catalysts at $523 \mathrm{~K}$.

Table 3.1. Rate expressions and parameters for the FTS kinetic model.

\begin{tabular}{|c|c|c|}
\hline Rate Expression & $\begin{array}{c}\mathrm{K}_{1} \mathrm{~K}_{2} \mathrm{~K}_{6} \mathrm{k}_{7} \\
\left(\mathrm{~mol} \mathrm{~h}^{-1} \text { at-g Fe } \mathrm{FPa}^{-1}\right)\end{array}$ & $\begin{array}{c}\mathrm{K}_{1} \mathrm{k}_{3} \\
\left(\mathrm{~mol} \mathrm{~h}^{-1} \text { at-g } \mathrm{Fe}^{-1} \mathrm{MPa}^{-1}\right)\end{array}$ \\
\hline $\mathrm{r}_{\mathrm{HC}}=\frac{\mathrm{K}_{1} \mathrm{~K}_{2} \mathrm{~K}_{6} \mathrm{k}_{7} \mathrm{P}_{\mathrm{CO}} \mathrm{P}_{\mathrm{H} 2}+\mathrm{K}_{1} \mathrm{k}_{3} \mathrm{P}_{\mathrm{CO}}}{\left(1+\mathrm{K}_{1} \mathrm{P}_{\mathrm{CO}}\right)^{2}}$ & $16.05 \pm 1.04$ & $2.70 \pm 0.44$ \\
\hline $\mathrm{r}_{\mathrm{H}_{2} \mathrm{O}}=\frac{\mathrm{K}_{1} \mathrm{~K}_{2} \mathrm{~K}_{6} \mathrm{k}_{7} \mathrm{P}_{\mathrm{CO}} \mathrm{P}_{\mathrm{H} 2}}{\left(1+\mathrm{K}_{1} \mathrm{P}_{\mathrm{CO}}\right)^{2}}$ & $15.68 \pm 1.59$ & - \\
\hline $\mathrm{r}_{\mathrm{CO}_{2}}^{\mathrm{p}}=\frac{\mathrm{K}_{1} \mathrm{k}_{3} \mathrm{P}_{\mathrm{CO}}}{\left(1+\mathrm{K}_{1} \mathrm{P}_{\mathrm{CO}}\right)^{2}}$ & - & $3.47 \pm 0.82$ \\
\hline
\end{tabular}

Figure 3.10 compares the experimental and model-predicted hydrocarbon formation rates. The reaction rate calculated with the kinetic expressions derived from our model is in good agreement with the measured rate data again consistent with the accuracy and validity of the elementary steps proposed and with the assumptions made in extracting the functional forms of the reaction rate equations.

In conclusion, the FTS mechanism proposed in this work contemplates the possibility of parallels pathways for $\mathrm{CO}$ activation over Fe-based catalysts. An indirect consequence from this mechanism is that oxygen atom removal pathways as water or carbon dioxide take place simultaneous and independently. 


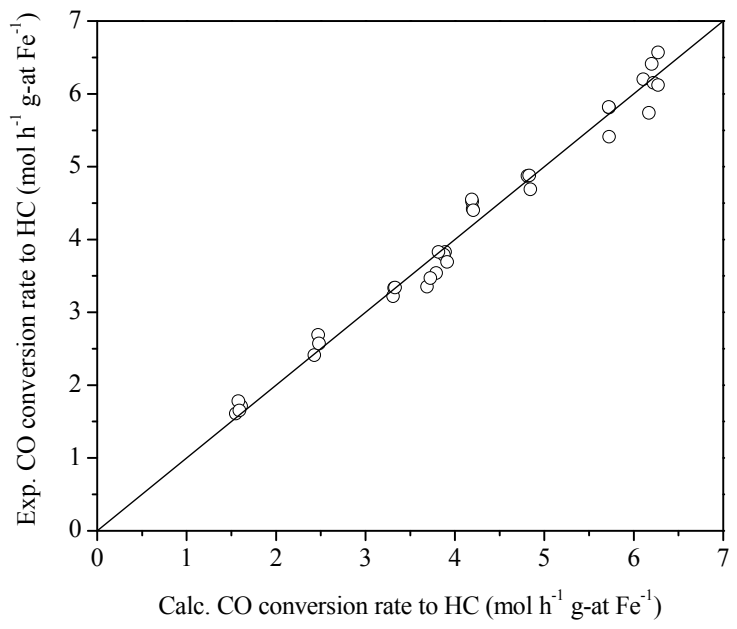

Figure 3.10. Parity plot for the experimental and calculated $\mathrm{CO}$ conversion rate to hydrocarbons.

The concentration of water in the gas phase increases with $\mathrm{CO}$ conversion levels. Our mechanism would then suggest that water molecules can be readsorbed onto active sites and influence potentially reaction rates. As $\mathrm{OH}^{*}$ concentration increases, the step in the mechanism that forms $\mathrm{CH}^{*}$ and $\mathrm{OH}^{*}$ species (step 7 in Scheme 3.1) becomes reversible and position of its thermodynamic equilibrium less favorable. Since the step preceding this one is quasi-equilibrated, this means that some of the $\mathrm{CO}^{*}$ species can have another opportunity to react either with adsorbed hydrogen $\left(\mathrm{H}^{*}\right)$ or with a vacant active site $\left(^{*}\right)$ to form surface carbon $\left(\mathrm{C}^{*}\right)$ and oxygen atoms $\left(\mathrm{O}^{*}\right)$, which can then react with another $\mathrm{CO}^{*}$ species to produce carbon dioxide. In summary, this reaction pathway is able to oxidize $\mathrm{CO}$ to $\mathrm{CO}_{2}$ using water, which is in fact the reaction known as the water-gas shift. We have found, therefore, a reaction mechanism for FTS with some elementary steps in common with WGS reaction and the mechanism for the latter is in fact contained within the catalytic sequences proposed herein for FTS.

These results have been confirmed with theoretical calculations about the Fischer-Tropsch Synthesis mechanism. This work has been done in close collaboration with Prof. Manos Mavrikakis, from the University of Wisconsin, Madison. From these DFT calculations, we have demonstrated that the $\mathrm{H}$-assisted $\mathrm{CO}$ dissociation pathway is energetically favored on a $\mathrm{Fe}(110)$ surface. Moreover, we have determined that the most probable intermediates are surface formyl species. These calculations and results support our hypothesis about the importance of the assistance of hydrogen species $\left(\mathrm{H}^{*}\right)$ in the $\mathrm{CO}$ dissociation event. We have also found that the unassisted $\mathrm{CO}$ cleavage also takes place to some extent. Therefore, this is in accordance with the experimental observation consisting in the formation of primary carbon dioxide, which is produced via the unassisted $\mathrm{CO}$ pathway. The results of this collaboration, which was not funded by this project, will be published within the next six months.

\subsection{Kinetic $\mathrm{H}_{2} / \mathbf{D}_{2}$ isotope effects on Fe-based catalysts.}

\subsection{1. $\mathrm{H}_{2} / \mathrm{D}_{2}$ effect on hydrocarbon formation rate.}

During this project, we have also analyzed the consistency between the proposed mechanism and the $\mathrm{H}_{2} / \mathrm{D}_{2}$ kinetic isotope effects $\left(\mathrm{r}_{\mathrm{H}} / \mathrm{r}_{\mathrm{D}}\right)$ measured on iron-based Fischer-Tropsch catalysts 
(Fe-Zn-K-Cu). The reaction mechanism proposed for FTS contains the two parallel pathways for $\mathrm{CO}$ activation on Fe-based catalysts. On one hand, adsorbed carbon monoxide species $\left(\mathrm{CO}^{*}\right)$ can be directly dissociated to form surface carbon atoms $\left(\mathrm{C}^{*}\right)$ which can be subsequently hydrogenated to produce the FTS monomers $\left(\mathrm{CH}_{2}^{*}\right)$. But at the same time, hydrogenation of undissociated carbon monoxide molecules leads also to the formation of surface monomers. Although both monomer formation routes occur simultaneously over the catalyst surface, our results showed that the hydrogen-assisted $\mathrm{CO}$ dissociation mechanism is predominant at typical $\mathrm{H}_{2}$ and $\mathrm{CO}$ partial pressures. According to this mechanism, dihydrogen and hydrogen atoms formed via its dissociation are involved in all proposed elementary steps, except for the unassisted $\mathrm{CO}$ dissociation. Therefore, kinetic deuterium isotope effects could be used as a probe of these kinetically relevant steps and to provide evidence for or against a specific mechanistic proposal because the rate constant for the reaction of the hydrogen compound $\left(\mathrm{k}_{\mathrm{H}}\right)$ differs of that obtained for the same reaction with the corresponding deuterium compound $\left(\mathrm{k}_{\mathrm{D}}\right)$ when a bond to hydrogen or deuterium is formed or broken in the kineticallyrelevant steps of a reaction. On the other hand, the thermodynamic deuterium isotope effect, namely, the effect of isotopic substitution on the equilibrium constant, can be used to indicate important characteristics of reaction equilibriums. Therefore, comparisons of rates and selectivities for reactions of $\mathrm{H}_{2} / \mathrm{CO}$ and $\mathrm{D}_{2} / \mathrm{CO}$ mixtures on iron-based catalysts can provide specific evidence about the nature of the kinetically-relevant steps.

Figure 3.11 shows the $\mathrm{CO}$ conversion rate to hydrocarbons as a function of the $\mathrm{CO}$ conversion level. It can be clearly seen that hydrocarbons formation rate is higher (about two times) when $\mathrm{D}_{2} / \mathrm{CO}$ reactants mixture is used instead of $\mathrm{H}_{2} / \mathrm{CO}$ reactants. It is also noted that hydrocarbon formation rate decreases when the $\mathrm{CO}$ conversion is increased for both reactant mixtures.

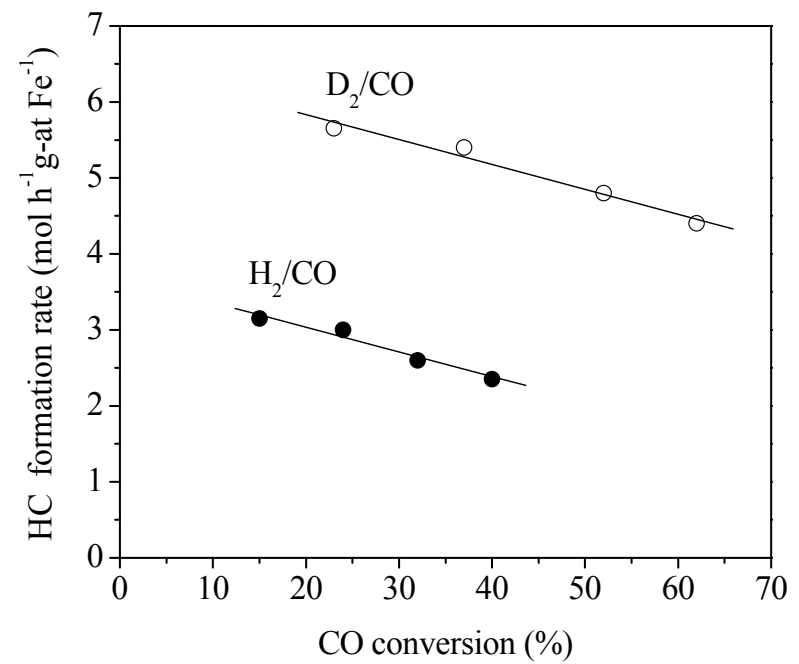

Figure 3.11. Hydrocarbon formation rates as a function of $\mathrm{CO}$ conversion for $\mathrm{H}_{2} / \mathrm{CO}$ or $\mathrm{D}_{2} / \mathrm{CO}$ reactants $(\mathrm{Zn} / \mathrm{Fe}=0.1, \mathrm{~K} / \mathrm{Fe}=0.02, \mathrm{Cu} / \mathrm{Fe}=0.01)$ at $508 \mathrm{~K}$ and $2.14 \mathrm{MPa}$.

We have previously shown that the $\mathrm{CO}$ conversion rate to hydrocarbon is given by:

$$
\mathrm{r}_{\mathrm{CH}_{2}}=\frac{K_{1} K_{2} K_{3} k_{4} \mathrm{P}_{\mathrm{CO}} \mathrm{P}_{\mathrm{H}_{2}}}{\left(1+K_{1} \mathrm{P}_{\mathrm{CO}}\right)^{2}}+\frac{K_{1} k_{5} \mathrm{P}_{\mathrm{CO}}}{\left(1+K_{1} \mathrm{P}_{\mathrm{CO}}\right)^{2}}
$$


where $\mathrm{r}_{\mathrm{CH}_{2}}$ is the $\mathrm{CO}$ conversion rate to hydrocarbons, $k_{\mathrm{i}}$ is the rate constant for step $i$, and $K_{i}$ is the equilibrium constant for step $i$. The use of $\mathrm{D}_{2}$ instead of $\mathrm{H}_{2}$ has no influence on the second term in Eq. 3.5. The observed kinetic isotope effect is, therefore, the combination of the individual effects of hydrogen or deuterium use on $K_{2}, K_{6}$ and $k_{7}$. Thus, the KIE is proportional to:

$$
\mathrm{KIE}=\frac{\mathrm{r}_{\mathrm{CH}_{2}}}{\mathrm{r}_{\mathrm{CD}_{2}}} \propto \frac{K_{2}^{H} K_{6}^{H} k_{7}^{H}}{K_{2}^{D} K_{6}^{D} k_{7}^{D}}=\frac{K_{2}^{H}}{K_{2}^{D}} \cdot \frac{K_{6}^{H}}{K_{6}^{D}} \cdot \frac{k_{7}^{H}}{k_{7}^{D}}
$$

where $\mathrm{r}_{\mathrm{CH}_{2}}$ and $\mathrm{r}_{\mathrm{CD}_{2}}$ are respectively the rate of hydrocarbon formation obtained with $\mathrm{H}_{2} / \mathrm{CO}$ and $\mathrm{D}_{2} / \mathrm{CO}$. The superscripts of the rate and equilibrium constants denote their provenance from the two respective reactant mixtures. The observed isotope effect results, in turn, from the combination of equilibrium $\left(K_{2}\right.$ and $\left.K_{6}\right)$ and kinetic $\left(k_{7}\right)$ isotope effects.

Rate and equilibrium constants within statistical mechanics formalism can be described as:

$$
K=\frac{\prod_{\mathrm{j}} \mathrm{Q}_{\mathrm{p}}^{v_{j}}}{\prod_{\mathrm{i}} \mathrm{Q}_{\mathrm{r}}^{v_{i}}} \text { and } k=\frac{\mathrm{k}_{\mathrm{B}} \mathrm{T}}{h} \frac{\mathrm{Q}^{\Xi}}{\prod_{\mathrm{i}} \mathrm{Q}_{\mathrm{r}}^{v_{i}}}
$$

where $(\mathrm{kT} / h)$ is a frequency factor; $\mathrm{Q}_{r}, \mathrm{Q}_{\mathrm{p}}$ and $\mathrm{Q}^{\Xi}$ are the partition functions for reactants, products, and transition state complexes; and $v_{i}$ and $v_{j}$ are the stoichiometric coefficients for reactants $i$ and products $j$. Therefore, the equilibrium isotope effect for $\mathrm{H}_{2}\left(\mathrm{D}_{2}\right)$ chemisorption is given by the following expression:

$$
\frac{K_{2}^{H}}{K_{2}^{D}}=\left(\frac{\mathrm{Q}_{\mathrm{D}_{2}}}{\mathrm{Q}_{\mathrm{H}_{2}}}\right) \cdot\left(\frac{\mathrm{Q}_{\mathrm{H}^{*}}}{\mathrm{Q}_{\mathrm{D}^{*}}}\right)^{2}
$$

Each ratio of the partition functions can be evaluated as a combination of the translational, rotational, vibrational and the electronic partition functions, and the equilibrium kinetic isotope effect can be evaluated to be:

$$
\frac{K_{2}^{H}}{K_{2}^{D}}=\left(\frac{\mathrm{Q}_{\mathrm{D}_{2}}}{\mathrm{Q}_{\mathrm{H}_{2}}}\right) \cdot\left(\frac{\mathrm{Q}_{\mathrm{H}^{*}}}{\mathrm{Q}_{\mathrm{D}^{*}}}\right)^{2}=5.68 \cdot \mathrm{e}^{\left[\left(\mathrm{E}_{\mathrm{H}_{2}}-2 \mathrm{E}_{\mathrm{H}^{*}}\right)-\left(\mathrm{E}_{\mathrm{D}_{2}}-2 \mathrm{E}_{\mathrm{D}^{*}}\right)\right] / \mathrm{RT}}
$$

The equilibrium isotope effect for $\mathrm{H}_{2}$ and $\mathrm{D}_{2}\left(K_{2}^{\mathrm{H}} / K_{2}^{\mathrm{D}}\right)$ depends on the relative chemisorption enthalpies of hydrogen and deuterium on Fe surfaces. Soller et al. [26] observed about 1.4 times more adsorption of $\mathrm{D}_{2}$ than $\mathrm{H}_{2}$ on $\mathrm{Cu}$ powder at $398 \mathrm{~K}$. Larger adsorption coefficients were measured for $\mathrm{D}_{2}$ than for $\mathrm{H}_{2}$ also on Ni samples [27,28]. In the case of Fe catalysts, previous studies have indicated that chemisorption of $\mathrm{D}_{2}$ is preferred over that of $\mathrm{H}_{2}$ [29]. Although we have not measured the relative coverage of hydrogen and deuterium atoms, indirect evidence of the larger deuterium coverage is derived from the lower olefin-to-paraffin ratios obtained when $\mathrm{D}_{2} / \mathrm{CO}$ mixture was used, which suggests a relatively higher surface coverage of deuterium atoms, i.e., $\theta_{\mathrm{D}^{*}}>\theta_{\mathrm{H}^{*}}$. It is expected, therefore, that $K_{2}^{\mathrm{H}} / K_{2}^{\mathrm{D}}<1$. 
It can be shown that the equilibrium isotope effect for the formation of the formyl intermediates ( $\mathrm{HCO}^{*}$ or $\left.\mathrm{DCO}^{*}\right)$ is given by the following expression:

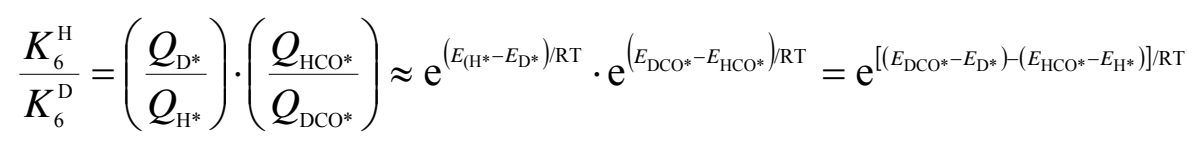

Previously studies conducted by Ozaki [30] revealed that the equilibrium constant for the addition of deuterium to an adsorbed species is generally larger than that for the addition of hydrogen. Therefore, the ratio of equilibrium constants for the formation of formyl species, $K_{6}^{\mathrm{H}} / K_{6}^{\mathrm{D}}$, should be lower than unity.

The kinetic isotope effect for the hydrogen-assisted $\mathrm{HCO}^{*}$ species dissociation (step 7) is therefore predicted to be given by:

$$
\begin{aligned}
& \frac{k_{7}^{\mathrm{H}}}{k_{7}^{\mathrm{D}}}=\left(\frac{Q_{\mathrm{CH}^{*} \mathrm{OH}}^{\Xi}}{Q_{\mathrm{CD}^{*} \mathrm{OD}^{*}}^{\Xi}}\right) \cdot\left(\frac{Q_{\mathrm{D}^{*}}}{Q_{\mathrm{H}^{*}}}\right) \cdot\left(\frac{Q_{\mathrm{DCO}^{*}}}{Q_{\mathrm{HCO}^{*}}}\right) \approx \mathrm{e}^{\left(E_{\mathrm{CD}^{*} \mathrm{O}^{*}}^{\bar{E}}-E_{\mathrm{CH}^{*} \mathrm{OH}}^{\bar{E}}\right) / \mathrm{RT}} \cdot \mathrm{e}^{\left(E_{\mathrm{H}^{*}}-E_{\mathrm{D}^{*}}\right) / \mathrm{RT}} \cdot \mathrm{e}^{\left(E_{\mathrm{HCO}}-E_{\mathrm{DCO}}\right) / \mathrm{RT}}= \\
& =\mathrm{e}^{\left[\left(E_{\mathrm{CD}^{*} O \mathrm{O}^{*}}^{\bar{E}}-E_{\mathrm{DCO}^{*}}-E_{\mathrm{D}^{*}}\right)-\left(E_{\mathrm{CH}^{*} \mathrm{OH}^{*}-E_{\mathrm{HCO}}}^{\bar{E}}-E_{\mathrm{H}^{*}}\right)\right] / \mathrm{RT}}
\end{aligned}
$$

Ozaki studied also the kinetic isotope effect for reactions involving the addition of hydrogen, concluding that $k^{\mathrm{H}}>k^{\mathrm{D}}$ in most cases. This is the result of the differences in the zero-point energies of deuterated and hydrogenated species, which is the primary origin of the effect. For kinetic isotope effects, we can assume that the step 4 in Scheme 1 is faster when $\mathrm{H}_{2} /$ CO synthesis gas is used $\left(k_{7}^{\mathrm{H}}>k_{7}^{\mathrm{D}}\right)$.

In conclusion, the overall inverse isotope effect $\left(r_{H} / r_{D}<1\right)$ for hydrocarbon formation indicates that hydrogen-containing species are involved in kinetically relevant steps. Moreover, the observed isotope effect is the result of the combination of kinetic and thermodynamic isotope effects. Since $r_{H} / r_{D}<1$, we can conclude that the thermodynamic isotope effects dominate the values measured for FTS reactions on representative Fe-based catalysts in this study.

\subsection{2. $\mathrm{H}_{2} / \mathrm{D}_{2}$ effect on $\mathrm{CO}_{2}$ formation rate}

Figure 3.12 shows the rate of carbon dioxide formation as a function of $\mathrm{CO}$ conversion at $508 \mathrm{~K}$ and 2.14 MPa total pressures with $\mathrm{H}_{2} / \mathrm{CO}$ and $\mathrm{D}_{2} / \mathrm{CO}\left(2 / 1\right.$ molar ratio). $\mathrm{CO}_{2}$ formation rates extrapolated to low $\mathrm{CO}$ conversion levels are non-zero, consistent with the primary nature of pathways for removal of oxygen as carbon dioxide (step 5 in Scheme 3.1) [7]. The primary $\mathrm{CO}_{2}$ formation rate is similar for $\mathrm{H}_{2} / \mathrm{CO}$ and $\mathrm{D}_{2} / \mathrm{CO}$ reactants, implying that the nature of syngas $\left(\mathrm{H}_{2} / \mathrm{CO}\right.$ or $\left.\mathrm{D}_{2} / \mathrm{CO}\right)$ did not influence the rate of oxygen removal as carbon dioxide. According to the reaction mechanism depicted in Scheme 3.1, the primary carbon dioxide formation rate is given by:

$$
\mathrm{r}_{\mathrm{CO}_{2}}^{\mathrm{p}}=\frac{K_{1} k_{3} \mathrm{P}_{\mathrm{CO}}}{\left(1+K_{1} \mathrm{P}_{\mathrm{CO}}\right)^{2}}
$$

According to Equation 3.12, the formation of the carbon dioxide through primary pathways is not influenced by the use of $\mathrm{H}_{2} / \mathrm{CO}$ or $\mathrm{D}_{2} / \mathrm{CO}$, in agreement with the experimental results. The isotopic content of the reactants, however, does affect the rate of carbon dioxide formation via secondary reactions, as expected from the involvement of $\mathrm{OH}^{*}$ and $\mathrm{OD}^{*}$ species in such reaction pathways. 


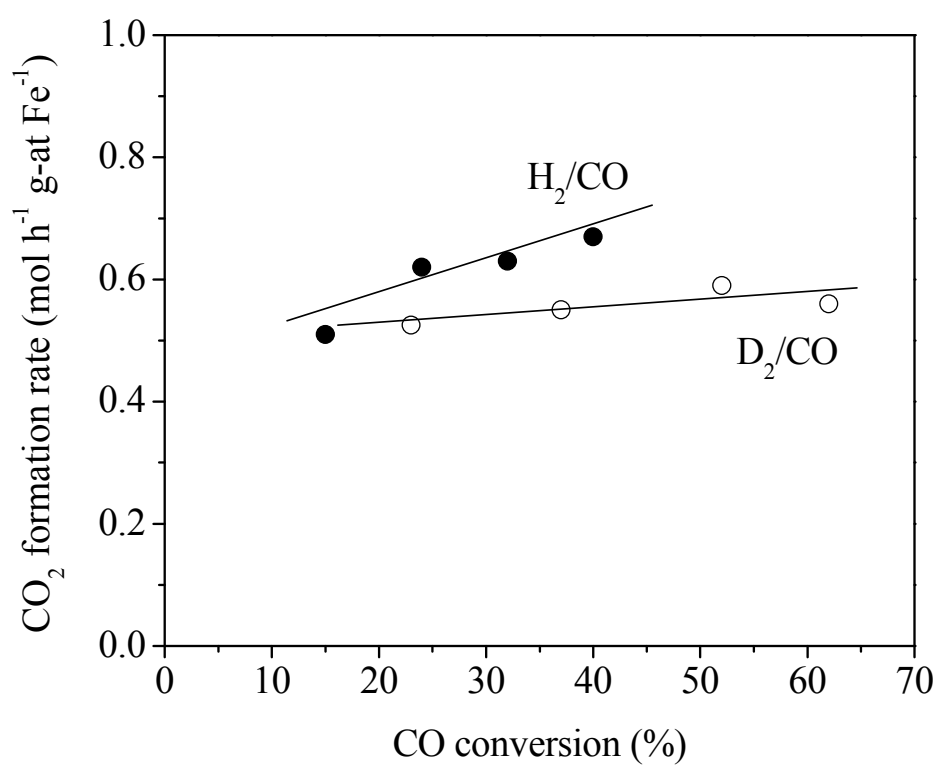

Figure 3.12. $\mathrm{CO}_{2}$ formation rate as a function of $\mathrm{CO}$ conversion for $\mathrm{H}_{2} / \mathrm{CO}$ or $\mathrm{D}_{2} / \mathrm{CO}$ reactants $(\mathrm{Zn} / \mathrm{Fe}=0.1, \mathrm{~K} / \mathrm{Fe}=0.02, \mathrm{Cu} / \mathrm{Fe}=0.01)$ at $508 \mathrm{~K}$ and $2.14 \mathrm{MPa}$.

\subsubsection{Ratio of hydrocarbon formation rates $\left(r_{H} / r_{D}\right)$}

The kinetic isotope effect can be expressed by the ratio $r_{H} / r_{D}$, where $r_{H}$ and $r_{D}$ are the rates of hydrocarbon formation rates $\mathrm{H}_{2} / \mathrm{CO}$ and $\mathrm{D}_{2} / \mathrm{CO}$ reactants, respectively. Since we do not have experimental values for both $\mathrm{r}_{\mathrm{H}}$ and $\mathrm{r}_{\mathrm{D}}$ at the same $\mathrm{CO}$ conversion, we have calculated the $r_{H}$ values by interpolation of rate $v s$. CO conversion to obtain values of $r_{D}$. Similarly, we have also obtained a fitted value of $r_{D}$ for each experimental value of $r_{H}$. Figure 3.13 shows the $r_{H} / r_{D}$ ratio for the rates of $\mathrm{CO}$ conversion and hydrocarbon and $\mathrm{CO}_{2}$ formation at different $\mathrm{CO}$ conversion levels.

The $\mathrm{r}_{H} / \mathrm{r}_{\mathrm{D}}$ ratio for the hydrocarbon formation is about 0.5 at low $\mathrm{CO}$ conversion values. We believe that the inverse isotope effect for the hydrocarbon formation $\left(\mathrm{r}_{\mathrm{H}} / \mathrm{r}_{\mathrm{D}}<1\right)$ is related to the higher surface coverage of $\mathrm{D}^{*}$ when compared to $\mathrm{H}^{*}$. The KIE decreases slightly with increasing $\mathrm{CO}$ conversion. This decrease could be a consequence of the lower average hydrogen partial pressure as the $\mathrm{CO}$ conversion increases. Hydrogen and deuterium partial pressures decrease slightly with increasing $\mathrm{CO}$ conversion. We speculate that surface hydrogen concentration $\left(\theta_{\mathrm{H}^{*}}\right)$ is more sensitive to the reduction of the $\mathrm{H}_{2}$ pressure than the surface deuterium coverage $\left(\theta_{\mathrm{D}^{*}}\right)$ because the adsorption coefficient of $\mathrm{D}_{2}$ is higher than the adsorption coefficient of $\mathrm{H}_{2}$. Accordingly, the rate of hydrocarbon formation decreases faster when $\mathrm{H}_{2} / \mathrm{CO}$ is used, and consequently, the $\mathrm{r}_{H} / \mathrm{r}_{\mathrm{D}}$ ratio for hydrocarbon formation decreases with increasing $\mathrm{CO}$ conversion (Figure 11).

The $\mathrm{r}_{\mathrm{H}} / \mathrm{r}_{\mathrm{D}}$ ratio for the rate of $\mathrm{CO}_{2}$ formation is greater than 1 (Figure 3.13) and it increases with $\mathrm{CO}$ conversion. The normal kinetic isotope effect for $\mathrm{CO}_{2}$ formation rates $\left(\mathrm{r}_{\mathrm{H}} / \mathrm{r}_{\mathrm{D}}>1\right)$ reflects the higher energy required for the cleavage of the $\mathrm{C}-\mathrm{D}$ bond relative to the $\mathrm{C}-\mathrm{H}$ bond in the intermediates required for secondary WGS reactions. 


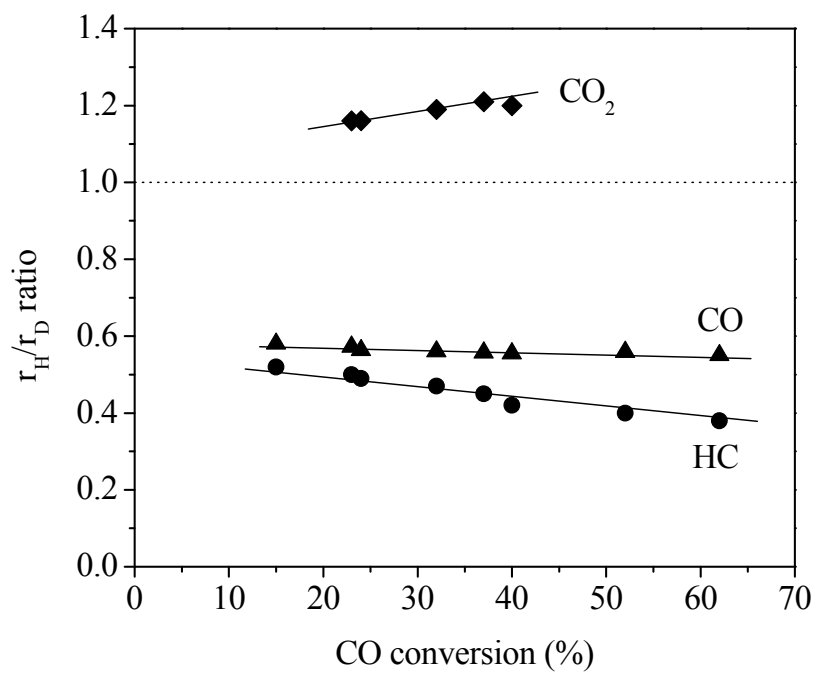

Figure 3.13. $\mathrm{r}_{\mathrm{H}} / \mathrm{r}_{\mathrm{D}}$ ratio for $\mathrm{CO}$ conversion, hydrocarbon and $\mathrm{CO}_{2}$ formation as a function of $\mathrm{CO}$ conversion for $\mathrm{H}_{2} / \mathrm{CO}$ or $\mathrm{D}_{2} / \mathrm{CO}$ reactants $(\mathrm{Zn} / \mathrm{Fe}=0.1, \mathrm{~K} / \mathrm{Fe}=0.02, \mathrm{Cu} / \mathrm{Fe}=0.01)$ at $508 \mathrm{~K}$ and $2.14 \mathrm{MPa}$.

Table 3.2 shows a summary of the consequences of using $\mathrm{D}_{2} / \mathrm{CO}$ instead of $\mathrm{H}_{2} / \mathrm{CO}$ over the hydrocarbons, water and primary carbon dioxide formation rates. The use of $\mathrm{D}_{2}$ instead of $\mathrm{H}_{2}$ increased hydrocarbons formation rate only through the $\mathrm{H}$-assisted $\mathrm{CO}$ dissociation mechanism, as indicated by the measured KIE values for the water formation rate. On the contrary, the unassisted pathway is not affected by $\mathrm{D}_{2}$, which is concluded by the fact that primary carbon dioxide formation rate does not depend on the use of $\mathrm{H}_{2} / \mathrm{CO}$ or $\mathrm{D}_{2} / \mathrm{CO}$.

Table 3.2. Summary of the KIE with a Fe-Zn-Cu-K catalyst $(\mathrm{Zn} / \mathrm{Fe}=0.1, \mathrm{~K} / \mathrm{Fe}=0.02$, $\mathrm{Cu} / \mathrm{Fe}=0.01$ ) at $508 \mathrm{~K}$ and $2.14 \mathrm{MPa}$.

\begin{tabular}{|c|c|c|c|}
\hline & $\begin{array}{c}\mathrm{r}_{\mathrm{H}} \\
\left(\mathrm{H}_{2} / \mathrm{CO}\right)\end{array}$ & $\begin{array}{c}\mathrm{r}_{\mathrm{D}} \\
\left(\mathrm{D}_{2} / \mathrm{CO}\right)\end{array}$ & KIE \\
\hline $\begin{array}{c}\text { Hydrocarbons } \\
\left(\mathrm{mol} \mathrm{h}^{-1} \mathrm{~g}_{\text {-at }} \mathrm{Fe}^{-1}\right)\end{array}$ & 3.70 & 6.50 & 0.57 \\
\hline $\begin{array}{c}\text { Water } \\
\left(\mathrm{mol} \mathrm{h}^{-1} \mathrm{~g} \text {-at Fe }{ }^{-1}\right)\end{array}$ & 3.26 & 6.02 & 0.54 \\
\hline $\begin{array}{c}\mathrm{CO}_{2} \\
\left(\mathrm{~mol} \mathrm{~h}^{-1} \mathrm{~g} \text {-at Fe }{ }^{-1}\right)\end{array}$ & 0.44 & 0.48 & 0.92 \\
\hline$\rho=\mathrm{r}_{\mathrm{HC}}^{\text {assisted }} / \mathrm{r}_{\mathrm{HC}}^{\text {unassisted }}$ & 7.4 & 12.5 & - \\
\hline
\end{tabular}




\section{FISCHER-TROPSCH SYNTHESIS ON COBALT CATALYSTS}

\section{Metal colloids as catalysts for the Fischer-Tropsch synthesis.}

In this section, we describe our efforts to develop synthetic protocols for Co-based metallic catalysts by using the precipitation of $\mathrm{Co}$ and $\mathrm{CoO}_{x}$ species and their subsequent impregnation onto supports modified to prevent significant interaction of oxide precursors with their surfaces. The objectives are to advance our understanding of the processes involved in deposition and stabilizing Co metal clusters and to use this knowledge to prepare catalysts with higher dispersion and oxidative and sintering stability.

\subsection{Experimental methods.}

4.1. Catalyst preparation.

$\mathrm{ZrO}_{2} / \mathrm{SiO}_{2}$ supports with $3.2 \mathrm{Zr} \mathrm{nm}{ }^{-2}$ were prepared by impregnation of $\mathrm{SiO}_{2}$ (Davison Grace $62,287 \mathrm{~m}^{2} \mathrm{~g}^{-1}$, treated in dry air at $873 \mathrm{~K}$ for $16 \mathrm{~h}$ before use) with an aqueous zirconyl nitrate (Aldrich, $99.99 \%$ ) in deionized and doubly-distilled water (DDI), and the impregnation was carried out at $373 \mathrm{~K}$ in air. The supports were treated in flowing dry air (Praxair, extra dry) by increasing the temperature from ambient to $773 \mathrm{~K}$ at $0.17 \mathrm{~K} \mathrm{~s}^{-1}$ and holding at this temperature for $3 \mathrm{~h}$.

$\mathrm{ZrO}_{2} / \mathrm{SiO}_{2}$ was also prepared via homogeneous deposition-precipitation. $6 \mathrm{~g}$ of $\mathrm{SiO}_{2}$ (Davison Grace $62,287 \mathrm{~m}^{2} \mathrm{~g}^{-1}$, treated in dry air at $873 \mathrm{~K}$ for $16 \mathrm{~h}$ before use), $2.8 \mathrm{~g}$ of zirconyl nitrate (Aldrich, $99.99 \%$ ) and $1 \mathrm{~g}$ of urea (ACROS, $99 \%$ ) were added into $50 \mathrm{~cm}^{3}$ of deionized and doubly-distilled water DDI under vigorous stirring at ambient temperature. The suspension was stirred at $363 \mathrm{~K}$ for $5 \mathrm{~h}$. After evaporation of water at $373 \mathrm{~K}$, the samples were treated in flowing dry air (Praxair, extra dry) by increasing the temperature from ambient to $773 \mathrm{~K}$ at $0.17 \mathrm{~K} \mathrm{~s}^{-1}$ and holding this temperature for $3 \mathrm{~h}$.

$\mathrm{ZrO}_{2} / \mathrm{SiO}_{2}$ was also prepared by using zirconium (IV) ethoxide. First, $10 \mathrm{~g}$ of $\mathrm{SiO}_{2}$ (Davison Grace 62, $287 \mathrm{~m}^{2} \mathrm{~g}^{-1}$, treated in dry air at $873 \mathrm{~K}$ for $16 \mathrm{~h}$ before use) was dried in ambient air at $398 \mathrm{~K}$ for $6 \mathrm{~h} .4 \mathrm{~g}$ of zirconium (IV) ethoxide (Alfa Aesar, $99 \%$ ), $2 \mathrm{~cm}^{3}$ of acetic acid (Fischer, 99.8\%) and $10 \mathrm{~g}$ of pre-treated $\mathrm{SiO}_{2}$ were added into $140 \mathrm{~cm}^{3}$ ethanol (Aldrich, 99.5\%) at ambient temperature in a dry box. The resulting suspension was stirred at ambient temperature for $12 \mathrm{~h}$. After filtering and washing with ethanol solution, the samples were treated in flowing dry air (Praxair, extra dry) by increasing the temperature from ambient to $953 \mathrm{~K}$ at $0.17 \mathrm{~K} \mathrm{~s}^{-1}$ and holding at this temperature for $3 \mathrm{~h} \mathrm{[31].}$

a) Preparation of Co supported catalysts via incipient wetness impregnation: $A \mathrm{Co} / \mathrm{SiO}_{2}(11$ wt.\%) was prepared by incipient wetness impregnation of $\mathrm{SiO}_{2}$ (Davison Grace 62, $287 \mathrm{~m}^{2} \mathrm{~g}^{-1}$, treated in dry air at $873 \mathrm{~K}$ for $16 \mathrm{~h}$ before use) with $\mathrm{Co}\left(\mathrm{NO}_{3}\right)_{2} \cdot 6 \mathrm{H}_{2} \mathrm{O}$ (Aldrich, 99.999\%) in DDI water. Impregnation was carried out in air at $373 \mathrm{~K}$. The catalyst was treated in flowing dry air (Praxair, extra dry, $1.67 \mathrm{~cm}^{3} \mathrm{~s}^{-1}$ ) by increasing the temperature from ambient to $673 \mathrm{~K}$ at $0.17 \mathrm{~K} \mathrm{~s}^{-1}$ and holding it there for $4 \mathrm{~h}$.

The $\mathrm{Co} / \mathrm{ZrO}_{2} / \mathrm{SiO}_{2}$ catalysts with different Co loading (11 wt.\%, $\left.20 \mathrm{wt} . \%\right)$ were prepared by incipient wetness impregnation of $\mathrm{ZrO}_{2} / \mathrm{SiO}_{2}\left(3.2 \mathrm{Zr} \mathrm{nm}{ }^{-2}\right)$ with $\mathrm{Co}\left(\mathrm{NO}_{3}\right)_{2} \cdot 6 \mathrm{H}_{2} \mathrm{O}$ (Aldrich, $99.999 \%$ ) in DDI water. Impregnation was carried out in air at $373 \mathrm{~K}$. The catalysts were treated in flowing dry air (Praxair, extra dry, $1.67 \mathrm{~cm}^{3} \mathrm{~s}^{-1}$ ) by increasing the temperature from ambient to $673 \mathrm{~K}$ at $0.17 \mathrm{~K} \mathrm{~s}^{-1}$ and holding there for $4 \mathrm{~h}$.

b) Preparation of Co supported catalysts via homogeneous deposition-precipitation: $0.72 \mathrm{~g}$ of urea (ACROS, $99 \%$ ) and $1.2 \mathrm{~g}$ of $\mathrm{Co}\left(\mathrm{NO}_{3}\right)_{2} \cdot 6 \mathrm{H}_{2} \mathrm{O}$ (Aldrich, $99.999 \%$ ) were added into 65 
$\mathrm{cm}^{3}$ of DDI water. After addition of $2 \mathrm{~g}$ of the $\mathrm{ZrO}_{2} / \mathrm{SiO}_{2}$ support $\left(3.2 \mathrm{Zr} \mathrm{nm}{ }^{-2}\right.$ ), the temperature of solution was increased to $363 \mathrm{~K}$ and held for $12 \mathrm{~h}$. The resulting pink suspension was subsequently cooled down to ambient temperature and filtered. The resulting solid was dried at $373 \mathrm{~K}$ in air and treated in flowing dry air (Praxair, extra dry) by increasing the temperature from ambient to $673 \mathrm{~K}$ at $0.17 \mathrm{~K} \mathrm{~s}^{-1}$ and holding it there for $4 \mathrm{~h}$.

c) Preparation of Co supported catalysts via inverse micelles: First, a toluene and DDI-water mixture was bubbled with Ar (Praxair, $99.9 \%$ ) for $2 \mathrm{~h}$ to remove the oxygen. $15 \mathrm{~g}$ of didodecyldimethylammonium bromide (DDAB, Aldrich, $>98 \%$ ) was dissolved in $104 \mathrm{~cm}^{3}$ of toluene (Aldrich, $99.8 \%$ ) to form a $0.3 \mathrm{~mol} \mathrm{~L}^{-1}$ micelle solution. $\mathrm{CoCl}_{2}(0.13 \mathrm{~g}$, Aldrich, 99.9 \%) was then added to above solution and sonicated to obtain a blue solution. $\mathrm{NaBH}_{4}(1.13 \mathrm{~g}$, Aldrich, $99.99 \%$ ) was then added in $30 \mathrm{~cm}^{3}$ of DDI water to produce a $1 \mathrm{~mol} \mathrm{~L}^{-1}$ solution using a separate baker. The $1 \mathrm{~mol} \mathrm{~L}^{-1} \mathrm{NaBH}_{4}$ solution was slowly added to already prepared micelle solution stirring vigorously to reduce $\mathrm{CoCl}_{2}$. A black colloid appears when the reaction is completed [32]. Subsequently, $0.5 \mathrm{~g}$ of $\mathrm{SiO}_{2}$ was added to the colloidal solution and stirred for $3 \mathrm{~h}$. Acetone solution (Aldrich, $99 \%$ ) was used to induce flocculation and then filtered. After using acetone and DDI water to remove the surfactant, the resulting solids were treated in flowing dry helium (Praxair, extra dry) by increasing the temperature from ambient to $573 \mathrm{~K}$ at $0.17 \mathrm{~K} \mathrm{~s}^{-1}$ and holding at this temperature for $3 \mathrm{~h}$.

\subsubsection{Catalyst characterization.}

Powder X-ray diffraction (XRD) measurements were carried out with a Siemens D5000 diffractometer using a $\mathrm{CuK}_{\alpha}$ radiation. The XRD patterns were recorded between $20^{\circ}<2 \theta<$ $70^{\circ}$ by step-scanning at $0.05^{\circ}$ increments.

Temperature-programmed reduction (TPR) experiments were performed in a flow unit equipped with a thermal conductivity detector (QS-10, Quantachrome Corp.). The sample was placed inside a U-type quartz reactor and treated in $20 \% \mathrm{H}_{2}$ (Praxair, 20 vol. $\% \mathrm{H}_{2}, 80$ vol.\% $\mathrm{Ar}, 1.33 \mathrm{~cm}^{3} \mathrm{~s}^{-1}$ ) by heating to $1123 \mathrm{~K}$ at $0.17 \mathrm{~K} \mathrm{~s}^{-1}$. The $\mathrm{H}_{2}$ concentrations were calibrated by reducing pure $\mathrm{CuO}$ samples.

Infrared spectra (IR) were recorded with a Mattson RS-1000 Spectrometer in the diffuse reflectance mode with a resolution of $4 \mathrm{~cm}^{-1}$. Samples were ground into fine powders, placed inside a cell positioned within a Praying Mantis mirror assembly (Harrick), and purged with pure $\mathrm{He}$ (Praxair, $99.999 \%$ ) before heating to $673 \mathrm{~K}$ at $0.17 \mathrm{~K} \mathrm{~s}^{-1}$. All spectra were recorded at ambient temperature.

Chemisorption data were collected with a Quantachrome 1C Autosorb apparatus. The samples were reduced in pure hydrogen (Praxair, 99.999\%) at $673 \mathrm{~K}$ for $1 \mathrm{~h}$ and then evacuated at this temperature for $10 \mathrm{~min}$ to remove chemisorbed hydrogen from the surface. The hydrogen chemisorption was carried out at $373 \mathrm{~K}$ (Quantasorb chemisorption analyzer). Adsorption isotherms were extrapolated to zero pressure to obtain the chemisorption uptakes. The dispersion values were calculated from hydrogen uptake and cobalt content assuming a 1:1 stoichiometry of $\mathrm{H}$ to surface cobalt atoms. The crystal diameter was calculated by assuming hemispherical crystallites $(\mathrm{d}(\mathrm{nm})=0.96 / \mathrm{D} ; \mathrm{D}=$ fractional dispersion) with random surface orientations exposing low-index crystal planes.

\subsubsection{Fischer-Tropsch synthesis.}

Fischer-Tropsch Synthesis (FTS) rates and selectivities were measured by using a fixedbed single-pass flow reactor with plug-flow hydrodynamics. The temperature of the catalyst bed was measured by a K-type thermocouple (Omega, 0.05-cm diameter, 46-cm length) located within a center thermowell. The flow rates of $\mathrm{H}_{2}$ [Praxair, 99.999\%] and synthesis gas (Praxair, 62 vol. \% $\mathrm{H}_{2}, 31$ vol.\% $\mathrm{CO}$ and 7 vol.\% $\mathrm{N}_{2}$ internal standard) were controlled by 
mass flow controllers (Porter Inc.). Catalysts $(105-177 \mu \mathrm{m})$ were diluted with $\mathrm{SiO}_{2}($ Davison Grace, $62,105-177 \mu \mathrm{m}$ ) at a mass ratio of 1:2.5 to avoid bed temperature gradients. Before the reaction, the catalyst was reduced in pure $\mathrm{H}_{2}$ (Praxair, $99.999 \%, 2.14 \mathrm{~cm}^{3}$ (g-catalyst. $\left.\mathrm{s}\right)^{-1}$ ) within the reactor by heating to $673 \mathrm{~K}$ at $0.17 \mathrm{~K} \mathrm{~s}^{-1}$ and holding for $5 \mathrm{~h}$. FTS reactions were carried out at $473 \mathrm{~K}$ using $2.15 \mathrm{MPa}$ of synthesis gas (Praxair, 62 vol.\% $\mathrm{H}_{2}, 31$ vol.\% $\mathrm{CO}$ and 7 vol.\% $\mathrm{N}_{2}$ internal standard). Reactant and product streams were analyzed by an on-line gas chromatograph (Agilent, 6890N) equipped with a cross-linked methyl silicone capillary column (HP-1) and a Porapak Q packed column, respectively [33].

\subsection{Effect of $\mathrm{ZrO}_{2}$ modification on $\mathrm{SiO}_{2}$ surface silanol groups}

Loading a layer of $\mathrm{ZrO}_{2}$ on $\mathrm{SiO}_{2}$ surface provides a simple but effective approach to terminate the hydroxyl groups on $\mathrm{SiO}_{2}$, an approach that may weaken the oxide-support interaction that inhibit reduction of supported metals oxides, $\mathrm{CoO}_{\mathrm{x}}$ in the case of this study [34]. In this report, $\mathrm{Zr}$ surface densities are reported as the number of $\mathrm{Zr}$ atoms per BET surface area $\left(\mathrm{Zr} \mathrm{nm}{ }^{-2}\right)$. Figure 4.1 shows the IR spectra of $\mathrm{SiO}_{2}$ and $\mathrm{ZrO}_{2} / \mathrm{SiO}_{2}$ samples treated in flowing helium at $673 \mathrm{~K}$ to remove physisorbed water. The $\mathrm{SiO}_{2}$ spectrum is dominated by an intense sharp band at $3735 \mathrm{~cm}^{-1}$, characteristic of isolated non-interacting surface silanol groups [35,36]. After $\mathrm{ZrO}_{2}$ deposition, each $\mathrm{ZrO}_{2} / \mathrm{SiO}_{2}$ sample exhibited the same isolated silanol band in the IR spectra but with lower intensity relative to pure silica. Also the intensities of silanol groups decreased with increasing $\mathrm{Zr}$ density on $\mathrm{ZrO}_{2} / \mathrm{SiO}_{2}$ surfaces (Table 1). Figure 4.2 shows that the Raman spectra of $\mathrm{ZrO}_{2} / \mathrm{SiO}_{2}$ samples contains a sharp band at 477 $\mathrm{cm}^{-1}$, attributed to three-dimensional amorphous zirconia [37-40]. These results show that these impregnation methods can terminate some of the hydroxyl groups on the $\mathrm{SiO}_{2}$ surface and that they give a high dispersion of $\mathrm{ZrO}_{2}$ for samples up to $20 \mathrm{wt} . \% \mathrm{ZrO}_{2}$ loading, for which $\mathrm{ZrO}_{2}$ crystallites are not detected in their Raman spectra.

Table 4.1. Si-OH intensities of various $\mathrm{ZrO}_{2} / \mathrm{SiO}_{2}$ samples

\begin{tabular}{ccc}
\hline Sample & Preparation method & Si-OH intensity \\
\hline $\mathrm{SiO}_{2}$ & $/$ & 1.03 \\
$\mathrm{ZrO}_{2} / \mathrm{SiO}_{2}$ & Impregnation of zirconium(IV) & 0.91 \\
$\left(0.8 \mathrm{Zr} \mathrm{nm}^{-2}\right)$ & $\begin{array}{c}\text { oxynitrate } \\
\mathrm{ZrO}_{2} / \mathrm{SiO}_{2}\end{array}$ & 0.68 \\
$\left(3.2 \mathrm{Zr} \mathrm{nm}^{-2}\right)$ & $\begin{array}{c}\text { Impregnation of zirconium(IV) } \\
\text { oxynitrate } \\
\mathrm{ZrO}_{2} / \mathrm{SiO}_{2}\end{array}$ & $\begin{array}{c}\text { Zirconium (IV) } \\
\text { ethoxide titrate }\end{array}$ \\
$\mathrm{ZrO}_{2} / \mathrm{SiO}_{2}$ & $\begin{array}{c}\text { Homogeneous } \\
\left(3.2 \mathrm{Zr} \mathrm{nm}^{-2}\right)\end{array}$ & 0.48 \\
\hline
\end{tabular}




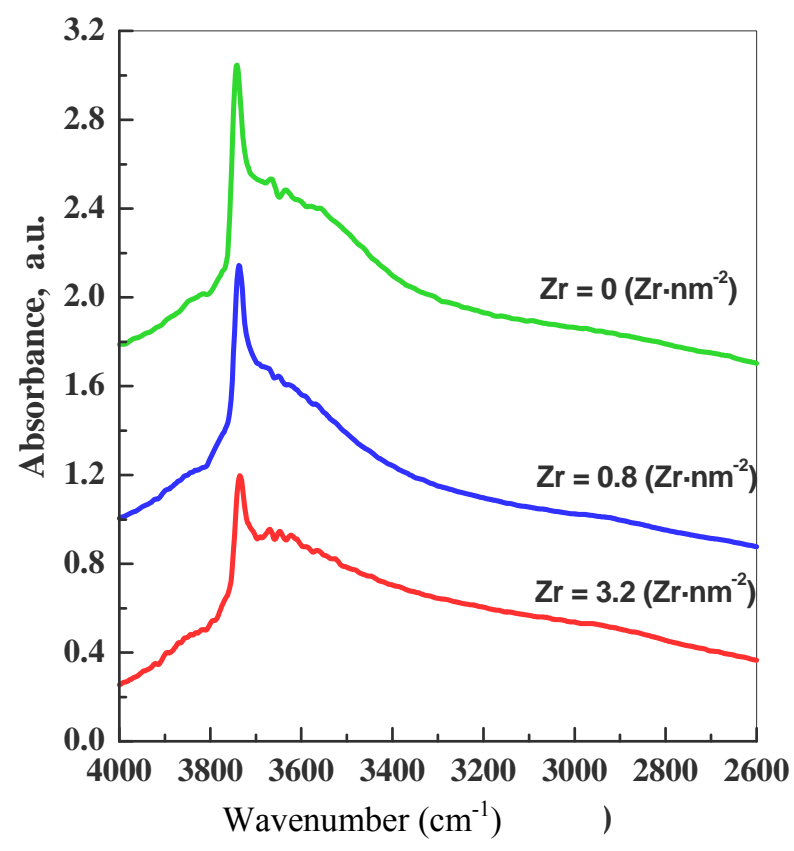

Figure 4.1. IR spectra of $\mathrm{SiO}_{2}$ and $\mathrm{ZrO}_{2} / \mathrm{SiO}_{2}$ samples

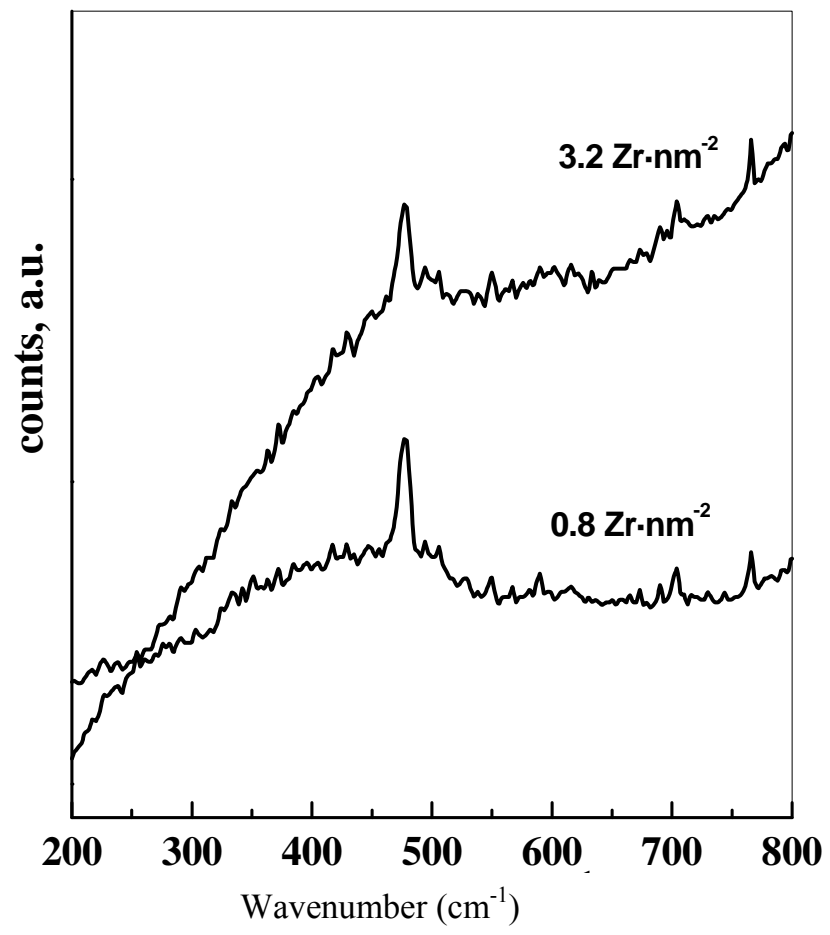

Figure 4.2. Raman spectra of $\mathrm{ZrO}_{2} / \mathrm{SiO}_{2}$ samples.

In addition to the impregnation method, surface titration (using zirconium (IV) ethoxide reacting with $\mathrm{Si}-\mathrm{OH}$ on the $\mathrm{SiO}_{2}$ in ethanol) and homogeneous deposition-precipitation methods were also used to terminate silanol groups, respectively. Although the intensities of hydroxyl groups on $\mathrm{ZrO}_{2} / \mathrm{SiO}_{2}$ prepared by the homogeneous deposition-precipitation process are weaker than in $\mathrm{ZrO}_{2} / \mathrm{SiO}_{2}$ prepared by impregnation (Table 4.1), some hydroxyl groups still exist on the surface. These data indicate that the hydroxyl groups on the $\mathrm{SiO}_{2}$ surface are 
difficult to be fully titrated by $\mathrm{ZrO}_{2}$ modification, perhaps because of steric factors or because of the difficulty in anchoring $\mathrm{Zr}$ precursors irreversibly on isolated silanol $\mathrm{OH}$ groups.

\subsection{Effect of preparation method on cobalt supported catalysts}

Monometallic cobalt supported catalysts were prepared by incipient wetness impregnation methods on $\mathrm{SiO}_{2}$ and $\mathrm{ZrO}_{2} / \mathrm{SiO}_{2}$ supports. The reduction dynamics of $\mathrm{CoO}_{\mathrm{x}} / \mathrm{SiO}_{2}$ and $\mathrm{CoO}_{\mathrm{x}} / \mathrm{ZrO}_{2} / \mathrm{SiO}_{2}$ precursors were examined by $\mathrm{H}_{2}$ temperature-programmed reduction $\left(\mathrm{H}_{2}-\right.$ TPR). Figure 4.3 shows their $\mathrm{H}_{2}$-TPR profiles. There are two main $\mathrm{H}_{2}$ consumption peaks, one at $500-600 \mathrm{~K}$ and the other at $600-700 \mathrm{~K}$. Previous studies [41] have shown that $\mathrm{Co}_{3} \mathrm{O}_{4}$ reduces to Co metal in two steps (Equations 4.1 and 4.2), leading to distinct peaks in the TPR profile. Therefore, the reduction peaks within $500-600 \mathrm{~K}$ can be attributed to reduction of $\mathrm{Co}_{3} \mathrm{O}_{4}$ to $\mathrm{CoO}$, and the $\mathrm{CoO}$ formed is then reduced subsequently to $\mathrm{Co}$ metal at higher temperatures resulting in broader peaks in the TPR profiles (Fig. 4.3). We also see that $\mathrm{CoO}_{\mathrm{x}} / \mathrm{ZrO}_{2} / \mathrm{SiO}_{2}$ samples exhibit similar reduction behavior as $\mathrm{CoO}_{\mathrm{x}} / \mathrm{SiO}_{2}$. Also, the calculated $\mathrm{H}_{2} / \mathrm{Co}$ ratios are close to the theoretical values $\left(\mathrm{H}_{2} / \mathrm{Co}=1.33\right)$, indicating that most of the $\mathrm{CoO}_{\mathrm{x}}$ species in these samples can be reduced to cobalt metal within a temperature range of 400-700 K.

$$
\begin{gathered}
\mathrm{Co}_{3} \mathrm{O}_{4}+\mathrm{H}_{2} \rightarrow 3 \mathrm{CoO}+\mathrm{H}_{2} \mathrm{O} \\
\mathrm{CoO}+\mathrm{H}_{2} \rightarrow \mathrm{Co}+\mathrm{H}_{2} \mathrm{O}
\end{gathered}
$$

Table 4.2 shows $\mathrm{H}_{2}$-chemisorption data for supported cobalt catalysts. We see that the application of $\mathrm{ZrO}_{2} / \mathrm{SiO}_{2}$ as a support improves the Co cluster dispersion leading to smaller Co cluster sizes than for $\mathrm{Co} / \mathrm{SiO}_{2}$. The above $\mathrm{H}_{2}-\mathrm{TPR}$ and $\mathrm{H}_{2}$-chemisorption results suggest that there is no strong interaction between the $\mathrm{SiO}_{2}$ support and the $\mathrm{CoO}_{\mathrm{x}}$ if the $\mathrm{CoO}_{\mathrm{x}}$ sizes are large $(>20 \mathrm{~nm})$, because almost $\mathrm{CoO}_{\mathrm{x}}$ species can be reduced at low temperatures $(<700 \mathrm{~K}) . \mathrm{ZrO}_{2}$ modification has only a weak influence on $\mathrm{CoO}_{\mathrm{x}}$ reduction rates but leads to an improvement in Co dispersion.

Table 4.2. $\mathrm{H}_{2}$ chemisorption results of cobalt supported catalysts

\begin{tabular}{ccc}
\hline Sample & Co dispersion (\%) & Average Co size (nm) \\
\hline 11 wt. $\% \mathrm{Co} / \mathrm{SiO}_{2}$ & 3.1 & 31 \\
11 wt. $\% \mathrm{Co} / \mathrm{ZrO}_{2} / \mathrm{SiO}_{2}$ & 4.3 & 22 \\
$3.2(\mathrm{Zr} \mathrm{nm})$ & & 20 \\
20 wt. $\% \mathrm{Co} / \mathrm{ZrO}_{2} / \mathrm{SiO}_{2}$ & 4.8 & \\
$3.2(\mathrm{Zr} \mathrm{nm})$ & & \\
\hline
\end{tabular}




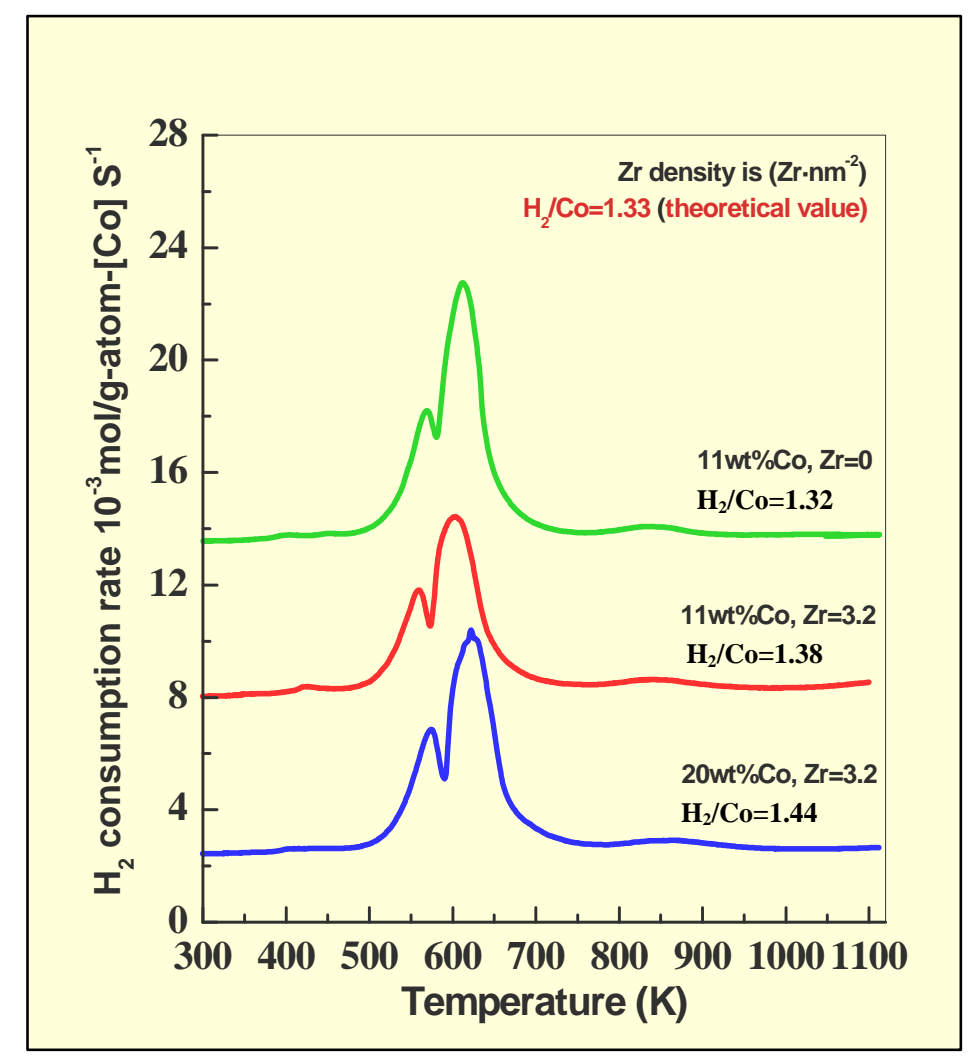

Figure 4.3. $\mathrm{H}_{2}$-TPR profiles of $\mathrm{CoO}_{\mathrm{x}}$ supported $\mathrm{SiO}_{2}$ and $\mathrm{ZrO}_{2} / \mathrm{SiO}_{2}$ precursors prepared by incipient wetness impregnation method

Colloidal nanoparticles of transition metals are attractive as precursors to synthesize monometallic or bimetallic supported catalysts, because they can be used to control the metal cluster structure, size, shape, and dispersion, which significantly influence catalyst productivity and selectivity $[42,43]$. Moreover, the direct synthesis of small metal clusters, instead of metal oxide clusters, on a support using colloidal methods avoids high temperature $\mathrm{H}_{2}$ reduction processes that often cause sintering of metal clusters. It therefore provides an opportunity to study the catalytic performance of small cobalt clusters in FTS reactions.

In the present study, we have successfully synthesized stable metallic cobalt particles via inverse micelle methods and deposited them onto $\mathrm{SiO}_{2}$ and modified $\mathrm{SiO}_{2}$ supports. Figure 4.4 shows TEM micrographs of the resulting $\mathrm{Co} / \mathrm{SiO}_{2}$ catalyst. In the TEM image, small particles with narrow size distributions $(3-5 \mathrm{~nm})$ are seen as black spots on the $\mathrm{SiO}_{2}$ surface, and the high resolution TEM micrographs also show that the individual particles (labeled as white circle in Fig. 4.4b) have lattice fringes consistent with crystalline clusters. X-ray diffraction patterns confirmed the cluster size and crystallinity conclusions reached from these micrographs. As seen in Figure 4.5, the XRD pattern for the $\mathrm{Co} / \mathrm{SiO}_{2}$ catalyst shows a weak and broad diffraction line at $\sim 45^{\circ}$, characteristic of cobalt metal [44]. According to the Scherrer equation, the Co cluster size given by this diffraction line is $\sim 5 \mathrm{~nm}$ in excellent agreement with TEM results. 


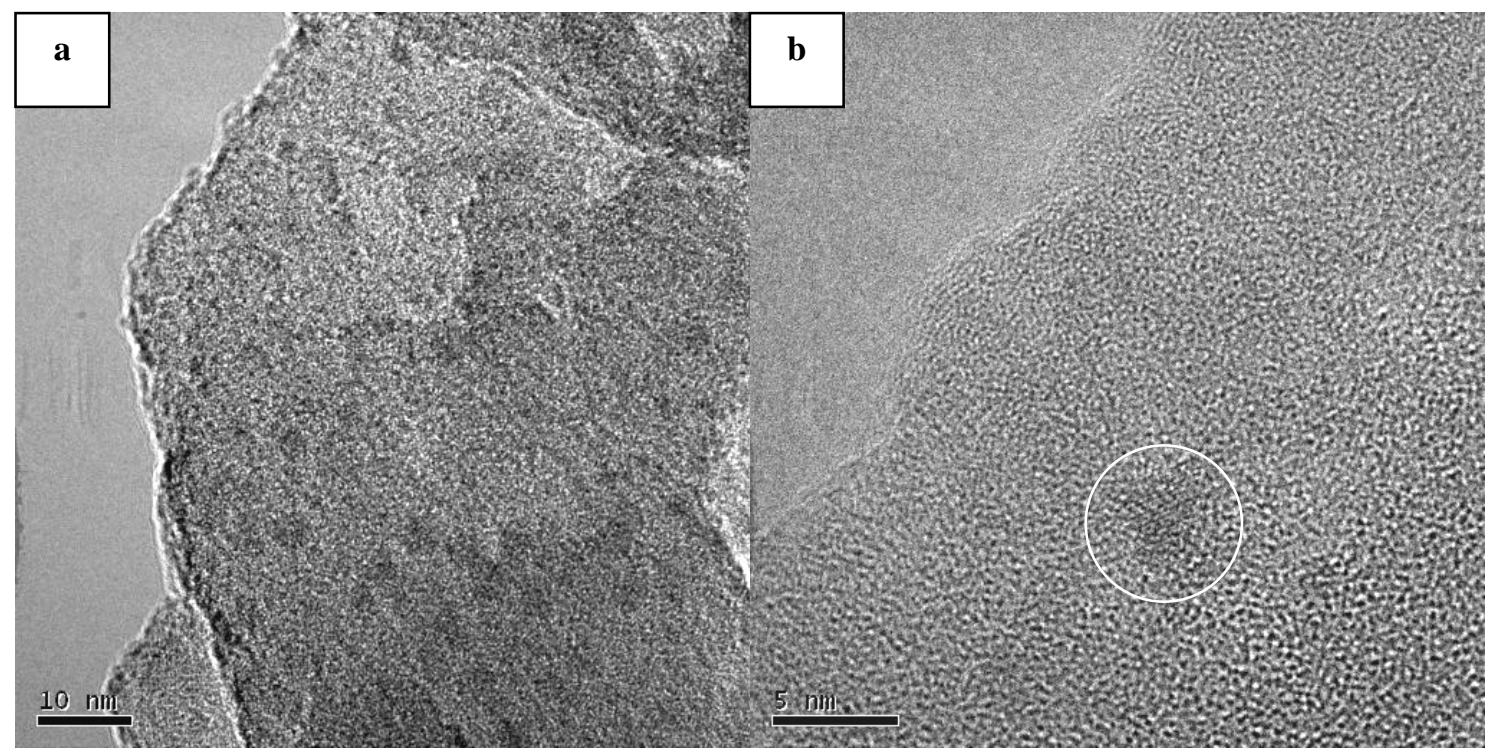

Figure 4.4. TEM photos of $\mathrm{Co} / \mathrm{SiO}_{2}$ prepared by inverse micelle method.

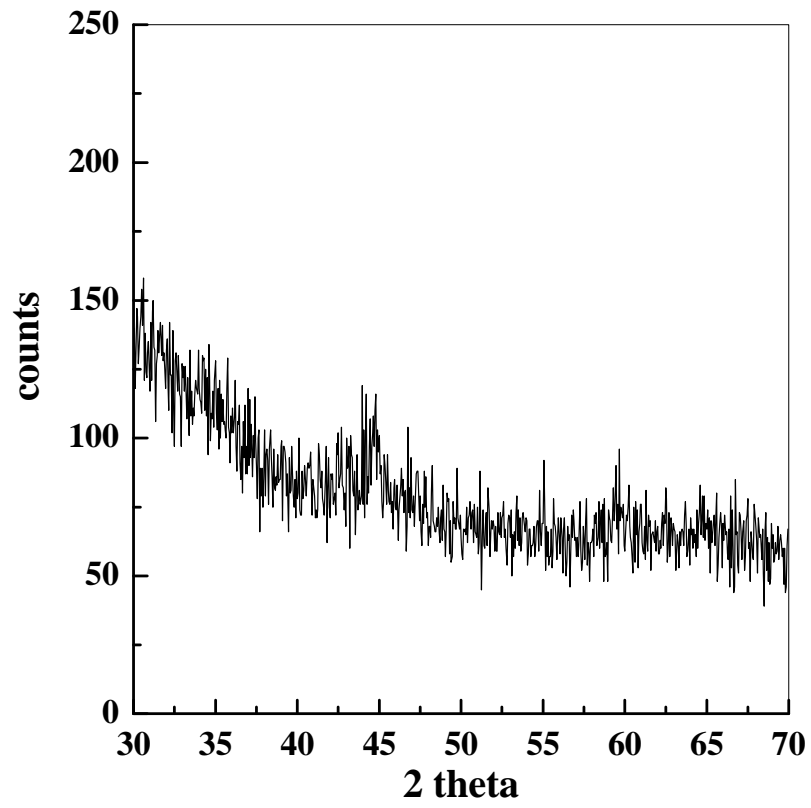

Figure 4.5. XRD pattern of $\mathrm{Co} / \mathrm{SiO}_{2}$ prepared by inverse micelle method.

The $\mathrm{H}_{2}$-TPR profile in Figure 4.6, however, shows a broad reduction peak at the high temperature ranges $(720-1100 \mathrm{~K})$ and the calculated $\mathrm{H}_{2} / \mathrm{Co}$ ratio for this peak is smaller than the value expected for $\mathrm{Co}_{3} \mathrm{O}_{4}$ reduction to $\mathrm{Co}$ metal (1.33). These data suggest that small $\mathrm{CoO}_{\mathrm{x}}$ and $\mathrm{Co}$ metal clusters co-exist on the $\mathrm{SiO}_{2}$ support. In fact, $\mathrm{NaBH}_{4}$ had already reduced the $\mathrm{CoCl}_{2}$ to metallic Co clusters in the solution, and these Co clusters did not consume $\mathrm{H}_{2}$ after loading on $\mathrm{SiO}_{2}$ surface. However, the surfactant removal step (acetone washing) can reoxidize the metallic Co clusters to $\mathrm{CoO}_{\mathrm{x}}$, because acetone can passivate the small metal particles at ambient temperatures. Once formed, these small $\mathrm{CoO}_{\mathrm{x}}$ species strongly interact with $\mathrm{SiO}_{2}$, requiring high temperatures to become again metallic (Fig. 4.6). These results indicate that the surfactant removal process and the prevention of the re-oxidation of small 
metallic Co clusters during this process are essential to form small supported Co metal clusters via colloidal methods.

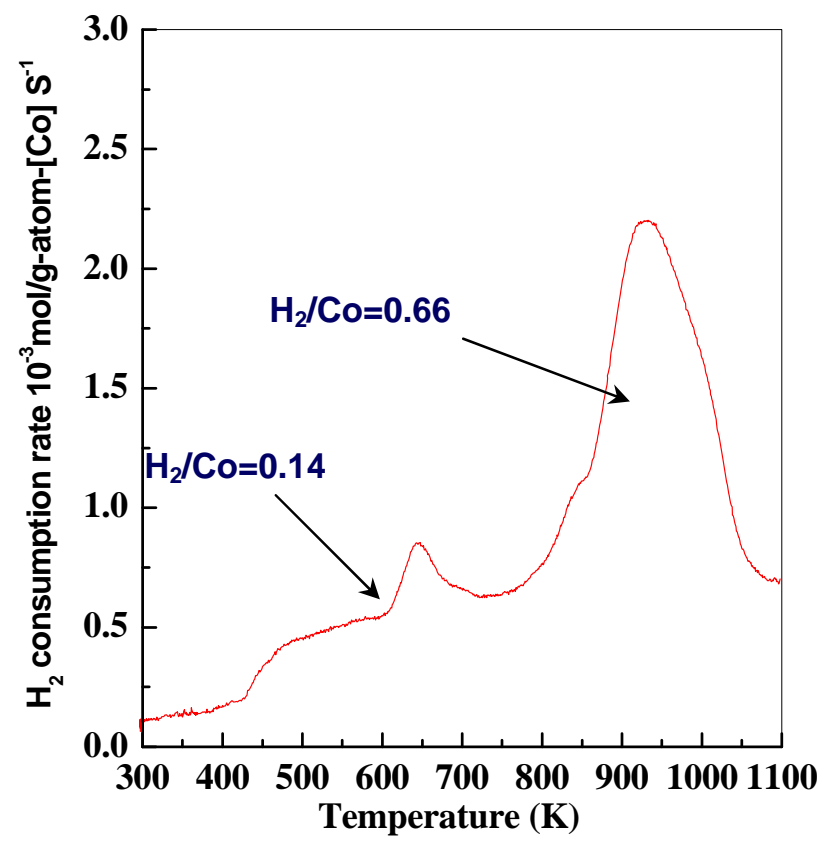

Figure 4.6. $\mathrm{H}_{2}-\mathrm{TPR}$ profile of $\mathrm{Co} / \mathrm{SiO}_{2}$ sample prepared by inverse micelle method.

Homogeneous deposition-precipitation (HDP) techniques provide another approach to synthesize high loadings of dispersed metal oxide clusters on supports $[45,46]$. This method allows the deposition of a soluble metal salt exclusively onto a support surface via gradual and homogeneous introduction of a precipitation agent, for example, hydroxyl ions, to prevent the nucleation of the precursor away from surfaces in the homogeneous phase. The decomposition of urea at $363 \mathrm{~K}$ was used to achieve the required slow and homogeneous increase in the $\mathrm{pH}$ of a suspension of $\mathrm{SiO}_{2}$ in a solution of Co nitrate. This method avoids the use of a surfactant. To weaken the interaction between the small $\mathrm{CoO}_{\mathrm{x}}$ and support, $\mathrm{ZrO}_{2} / \mathrm{SiO}_{2}$ was used as support instead of $\mathrm{SiO}_{2}$. Figure 7 shows the $\mathrm{H}_{2}$-TPR characterization results for the $\mathrm{CoO}_{\mathrm{x}} / \mathrm{ZrO}_{2} / \mathrm{SiO}_{2}$ sample derived from the HDP method. It shows two reduction peaks at relatively low temperatures $(375-650 \mathrm{~K})$ but also gives some reduction peaks at temperatures above $800 \mathrm{~K}$, which appear to reflect strong interactions between small $\mathrm{CoO}_{\mathrm{x}}$ species and the support. Hence the modification of $\mathrm{SiO}_{2}$ surfaces by $\mathrm{ZrO}_{2}$ cannot prevent the formation of some strongly interacting $\mathrm{CoO}_{x}$ species on $\mathrm{SiO}_{2}$ when $\mathrm{CoO}_{x}$ particles are small, because of residual $\mathrm{OH}$ groups on $\mathrm{SiO}_{2}$ surfaces (Fig. 4.1, Table 4.1). 


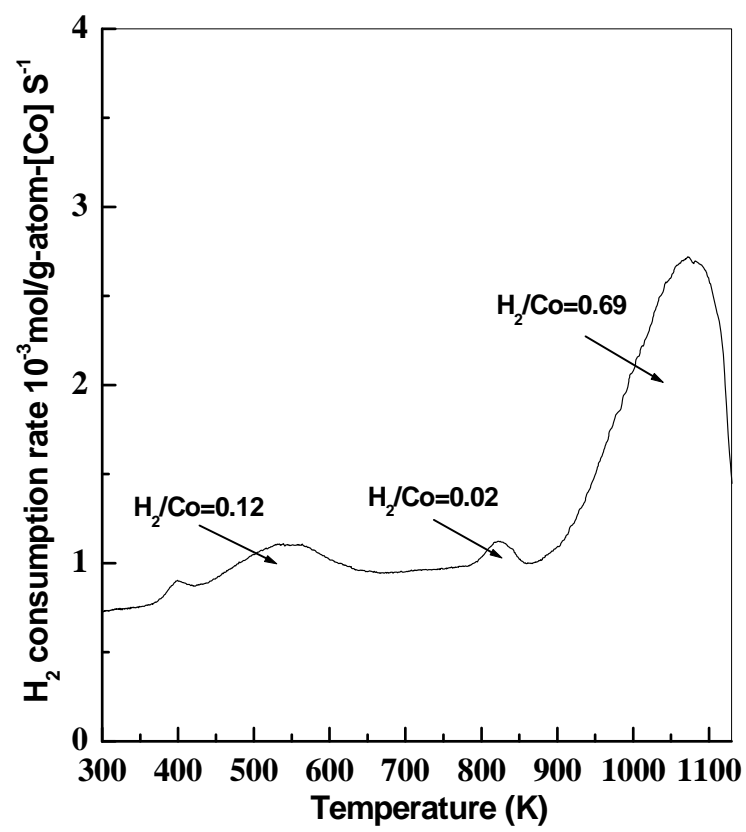

Figure 4.7. $\mathrm{H}_{2}$-TPR profile of $\mathrm{CoO}_{\mathrm{x}} / \mathrm{ZrO}_{2} / \mathrm{SiO}_{2}\left(11 \mathrm{wt} . \% \mathrm{Co}, 3.2 \mathrm{Zr} \mathrm{nm}{ }^{-2}\right.$ ) sample prepared via homogeneous deposition-precipitation

Table 4.3 shows FTS results for monometallic supported Co catalysts. The Co-time yield is defined as the mole of $\mathrm{CO}$ converted per unit time per g-atom $\mathrm{Co}$ and $\mathrm{Co}$ site-time yield is defined as the mole of $\mathrm{CO}$ converted per unit time per surface $\mathrm{Co}$ atom (measured by $\mathrm{H}_{2}$ chemisorption) [41]. Since most of the $\mathrm{CoO}_{\mathrm{x}}(>90 \%)$ cannot be reduced at low temperatures $(<673 \mathrm{~K})$ on catalysts prepared by inverse micelle or homogeneous deposition-precipitation methods, these catalysts are not included in Table 4.3.

The use of $\mathrm{ZrO}_{2} / \mathrm{SiO}_{2}$ as a support improves FTS rates (Co site-time yield and Co-time yield) and $\mathrm{C}_{5+}$ selectivity (from 76 to $86 \%$ ) while decreasing $\mathrm{CH}_{4}$ selectivity by a factor of $\sim 2$ at the same Co content (Table 4.3). These data suggest that the modification of $\mathrm{ZrO}_{2}$ on $\mathrm{SiO}_{2}$ surface not only improves the Co clusters dispersion leading to more accessible sites, but also favors the formation of larger hydrocarbon molecules.

Table 4.3. FTS reaction results of monometallic Co supported catalysts

\begin{tabular}{|c|c|c|c|c|c|c|c|}
\hline Catalyst & $\begin{array}{c}\text { Co } \\
\text { (wt \%) }\end{array}$ & $\begin{array}{l}\mathrm{Zr} \text { density } \\
\left(\mathrm{Zr} \cdot \mathrm{nm}^{-2}\right)\end{array}$ & $\begin{array}{l}\text { Co } \\
\text { size } \\
(\mathrm{nm})\end{array}$ & $\begin{array}{l}\text { Co-time yield } \\
\left(\mathrm{mol} \mathrm{h}^{-1} \mathrm{~g} \text {-at }\right. \\
\left.\mathrm{Co}^{-1}\right)\end{array}$ & $\begin{array}{c}\text { Co site-time } \\
\text { yield } \\
\left(\mathrm{mol} \mathrm{h}^{-1} \mathrm{~g} \text {-at }\right. \\
\left.\mathrm{Co}^{-1}\right) \\
\end{array}$ & $\begin{array}{c}\mathrm{CH}_{4} \\
\text { selectivity } \\
(\%)\end{array}$ & $\begin{array}{c}\mathrm{C}_{5+} \\
\text { selectivity } \\
(\%)\end{array}$ \\
\hline $\mathrm{Co} / \mathrm{SiO}_{2}$ & 11 & 0 & 31 & 2.4 & 77.4 & 12.8 & 75.9 \\
\hline $\begin{array}{c}\mathrm{Co} / \\
\mathrm{ZrO}_{2} / \mathrm{SiO}_{2}\end{array}$ & 11 & 3.2 & 22 & 3.5 & 81.4 & 6.5 & 86.5 \\
\hline
\end{tabular}

CO conversion is $17-28 \%$ 


\section{REFERENCES.}

1. S. Li, S. Krishnamoorthy, A. Li, G. D. Meitzner, E. Iglesia, J. Catal. 206 (2002) 202.

2. S. Li, A. Li, S. Krishnamoorthy, E. Iglesia, Catal. Lett. 77 (2001) 197.

3. S. Soled, E. Iglesia, S. Miseo, B.A. DeRites, R.A. Fiato, Topics Catal. 2 (1995)193

4. S.A. Eliason, C.H. Bartholomew, Appl. Catal. A: Gen. 186 (1999) 229.

5. M. Luo, R. O’Brien, B.H. Davis, Catal. Lett. 98 (2004) 17.

6. G.P. van der Laan, A.A.C.M Beenackers, Catal. Rev. Sci. Eng. 41 (1999) 255.

7. S. Krishnamoorthy, A. Li, E. Iglesia, Catal. Lett 80 (2002) 77.

8. J. Xu, C.H. Bartholomew, J. Sudweeks, D.L. Eggett, Topics Catal. 26 (2003)55.9. D.B.

Bukur, X. Lang, D. Mukesh, W.H. Zimmerman, M.P. Rosynek, C. Li, Ind. Eng. Chem. Res. 29 (1990) 1588.

10. A.P. Raje, R. O’ Brien, B.H. Davis, J. Catal. 180 (1998) 36.

11. B. Wu, L. Bai, Z. Zhang, H. Xiang, Y.W. Li, Fuel 83 (2004) 205.12. D.B. Bukur, S.A.

Patel, X. Lang, Appl. Catal. 61 (1990) 329.13. S. Li, G.D. Meitzner, E. Iglesia, J. Phys. Chem. B 105 (2001) 5743.

14. C.S. Kuivila, P.C. Stair, J.B. Butt, J. Catal. 118 (1989) 299.

15. J.P. Reymond, P. Meriaudeau, S.J. Teichner, J. Catal 75 (1982) 39.

16. J.F. Shultz, W.K. Hall, T.A. Dubs, R.B. Anderson, J. Am. Chem. Soc. 28 (1956) 282.

17. E.S. Lox, G.F. Froment, Ind. Eng. Chem. Res. 32 (1993) 71.

18. A. Raje, B.H. Davis, ACS Petrol. Chem. Div. Preparation 249 (1996).

19. G.A. Huff, Jr., C.N. Satterfield, Ind. Eng. Chem. Process Des. Dev. 23 (1984) 696.

20. I.C. Yates, C.N. Satterfield, Energy Fuels 5 (1991) 168.

21. V. Ponec, W.A. van Barneveld, Ind. Eng. Chem. Prod. Res. Des. 4 (1979) 268.

22. B.H. Davis, Fuel Process. Technol. 71 (2001) 157.

23. A.T. Bell, Catal. Rev. Sci. Eng. 23 (1981) 203.

24. G.H. Graaf, J.G.M. Winkelman, E.J. Stamhuis, A.A.C.M. Beenackers, Chem. Eng. Sci. 43 (1988) 2161.

25. G.P. van der Laan, A.A.C.M. Beenackers, Appl. Catal. 193 (2000) 39.

26. T. Soller, S. Goldwasser, R.A. Beebe, J. Am. Chem. Soc. 58 (1936) 1703.

27. F. de Pauw, J.C. Jungers, Bull. Soc. Chim. Belg. 57 (1948) 618.

28. J. Nicolai, M. Hout, J.C. Jungers, Bull. Soc. Chim. Belg. 55 (1946) 160.

29. J.T. Kummer, P.H. Emmet, J. Phys. Chem. 55 (1951) 337.

30. A. Ozaki, Isotopic studies of heterogeneous catalysis, Academic Press, New York, 1977. 
31. A.C.Q.M. Meijers, A.M. de Jong, L.M.P. van Gruijthuijsen, J.W. Niemantsverdriet, Appl. Catal. 70 (1991) 53.

32. X.M. Lin, C.M. Sorensen, K.J. Klabunde, G.C. Hadjipanayis, Langmuir 14 (1998) 7140.

33. S. Li, S. Krishnamoorthy, A. Li, G. D. Meitzner, E. Iglesia, J. Catal. 206 (2002) 202.

34. A. Hoek, M.F.M. Post, J.K. Minderhoud, P.W. Lednor, U.S. Patent 4499209 (Shell Oil Company).

35. B.A. Morrow, A.J. McFarlan, J. Phys. Chem. 96 (1992) 1395.

36. B.A. Morrow, A.J. McFarlan, Langmuir 7 (1991) 1695.

37. X. Gao, J.L.G. Fierro, I.E. Wachs, Langmuir 15 (1999) 3169.

38. H. Arash, M. Ishigame, Phys. Status Solidi A 71 (1982) 313.

39. E. Anastassakis, B. Papanicolaou, I.M. Asher, J. Phys. Chem. Solids 36 (1975) 667.

40. V.G. Keramidas, W.B. White, J. Am. Ceram. Soc. 57 (1974) 22.

41. E. Iglesia, S.L. Soled, R.A. Fiato, G.H. Via, J. Catal. 143 (1993) 345.

42. R. Narayanan, M.A. El-Sayed, J. Catal. 234 (2005) 348.

43. H. Einaga, M. Harada, Langmuir 21 (2005) 2578.

44. G.N. Glavee, K.J. KIabunde, C.M. Sorensen, G.C. Hadjipanayis, Inorg. Chem. 32 (1993) 474.

45. P. Burattin, M. Chen, C. Louis, J. Phys. Chem. B 102 (1998) 2722.

46. P. Burattin, M. Chen, C. Louis, J. Phys. Chem. B 103 (1999) 6171. 